\title{
A Peace Baby Boom? Evidence from Colombia's Peace Agreement*
}

\author{
María Elvira Guerra-Cújar ${ }^{\dagger} \quad$ Mounu Prem Paul Rodríguez-Lesmes $^{\S}$ \\ Juan F. Vargas $₫$
}

December 13, 2022

\begin{abstract}
Violence affects households' preferences, perceptions, and constraints regarding fertility choices. What happens when violence ends? Using administrative data from Colombia, we find that the end of a long internal conflict differentially increased fertility by 2.6 percent in areas exposed to violence. The effect is present across all reproductive ages and larger in municipalities with higher levels of violence exposure at baseline. This differential fertility increase is not driven by health supply indicators, by the mortality of newborns and infants, or by differential migration. We interpret this evidence as consistent with an increased optimism and with better economic perspectives.
\end{abstract}

JEL Codes: I12; I15

Keywords: fertility; pregnancy; armed conflict; violence

*This paper developed from Guerra's thesis to obtain the degree of MA in Economics of Public Policy at Universidad del Rosario. We thank Mariana Blanco, Dolores de la Mata, Michele Di Maio, Gema LaxMartínez, Stanislao Maldonado, Pablo Querubín, Santiago Saavedra, and seminar participants at the AL CAPONE Conference and Universidad Nacional. Carolina Velez and Carolina Bernal provided outstanding research assistance. We acknowledge funding from the Alianza EFI-Colombia Cientifica grant with code 60185 and contract number FP44842-220-2018. Prem acknowledges IAST funding from the French National Research Agency (ANR) under the grant ANR-17-EURE-0010 (Investissements d'Avenir program). Declarations of interest: none.

${ }^{\dagger}$ School of Economics, Universidad del Rosario. E-mail: mariael.guerra@urosario.edu.co

‡Einaudi Institute for Economics and Finance. E-mail: francisco.munoz@eief.it

§School of Economics, Universidad del Rosario. E-mail: paul.rodriguez@urosario.edu.co

ISchool of Economics, Universidad del Rosario. E-mail: juan.vargas@urosario.edu.co 


\section{Introduction}

Crime and violence impose a magnificent economic and social burden. At the household level, violent environments shape long-term choices. Fertility decisions are a key example (Brück and Schindler, 2009): in contexts of high perceived risk of mortality and disability, and where the supply of health care services is disrupted, households may be unwilling to take actions that have specific long-term consequences, such as fertility. Indeed, violent conflicts may have profound impacts on the three categories of demographic and socioeconomic factors that shape fertility choices, as described by Kohler et al. (2006): socioeconomic incentives, social feedback effects, and institutional settings. Thus, events that mark the end of a period of violence may be followed by increases in fertility rates. Perhaps the most prominent historical example of the positive relationship between peace and fertility is the post-World War II baby boom. ${ }^{1}$

But we know less about the fertility response to the end of lower-intensity internal conflicts that span over decades. There, post-conflict fertility rebounds are not obvious given how an inter-generational exposure to violence shapes how people learn to coexist with conflict, and thus changes long-term households' preferences, perceptions, and constraints. This reduces the scope of a post-conflict reversion to the pre-conflict mean.

Using detailed administrative data from vital statistics as well as the records from all individuals' interactions with the health system, this paper documents a differential increase in fertility rates in municipalities formerly exposed to the Revolutionary Armed Forces of Colombia (FARC from its Spanish acronym), after this insurgency stopped engaging in violence following peace negotiations with the Colombian government. We do so using a difference-in-differences empirical strategy that compares the evolution of fertility in areas traditionally more affected by FARC's violence to other places. We find that after the start of a permanent ceasefire declared in December 2014, Colombia's secular reduction of the total fertility rate slowed down in places that previously experienced more FARC violence. This translates into a differential fertility increase, which implies that Colombia's post-ceasefire baby boom is more nuanced than the historical instances of absolute fertility increases experienced in other contexts.

Quantitatively, we find that a one-standard-deviation increase in the number of FARC attacks per 10,000 inhabitants over the period 2011-2014 caused a statistically significant dif-

\footnotetext{
${ }^{1}$ In general, episodes of fertility rebound have also been documented in the aftermath of other highmortality episodes such as natural disasters (Nobles et al., 2015; Finlay, 2009; Caldwell, 2006).
} 
ferential increase of 2.6 percent in the total fertility rate after the start of the ceasefire. ${ }^{2}$ This is robust to including municipality and department-year fixed effects, that flexibly control for any municipal-specific time-invariant heterogeneity and for any temporal shock that affects fertility rates of all the municipalities of a given department, respectively. The results are also largely unchanged when we control for pre-ceasefire municipal characteristics -including variables that account for the presence of illegal activities-interacted with year fixed effects, therefore accounting for differential changes across municipalities with different values of such attributes; or when we control for municipal-specific trends or the baseline comparison group to municipalities a priory more comparable to those exposed to FARC violence, including those that experienced violence perpetrated by other illegal groups, a truncated sample that maximizes the overlap of treated and control areas following Crump et al. (2009), and the adoption of a synthetic control difference-indifferences estimator recently proposed by Arkhangelsky et al. (2021). The estimates are also robust to using alternative definitions of exposure to FARC violence.

We explore whether the effect found for the total fertility rate is driven by specific age brackets. To that end, we compute age-specific fertility rates across five-year age groups over the age range of 15 to 44 . We find that the ceasefire caused a differential fertility increase across the board, and the magnitude of the effect is similar across the different age brackets.

The validity of our estimates and the extent to which they can be interpreted as causal depend on the assumption that, absent the ceasefire, the fertility rate would have followed the same trend in municipalities highly exposed to FARC violence and control areas. We find evidence that is consistent with this assumption using a battery of both parametric and non-parametric techniques. In particular, we document that, prior to the ceasefire, the fertility rate did not feature any significant differential trend in places highly affected by FARC violence.

We also investigate the mechanisms associated with the differential increase in fertility rates following the ceasefire and find robust suggestive evidence consistent with: i) a generalized feeling of improved security, and ii) better economic perspectives. We argue that, taken together, these perceptions drive fertility choices in former FARC-exposed municipalities. For instance, we find that the differential increase in fertility rates is larger

\footnotetext{
${ }^{2}$ After the ceasefire, FARC's offensive activity dropped by 98 percent (CERAC, 2016), and the cases of landmines explosions dropped by 76 percent. Indeed, by declaring a ceasefire, FARC signalled its unified command structure and its commitment to reaching a peace agreement by refraining from initiating attacks or responding violently to actions perpetrated either by the military or other armed groups.
} 
in places that suffered more intense violence prior to the ceasefire, witnessed more landmines explosions, abducted more children to fight the conflict, and expelled more internal refugees prior to the start of the ceasefire. This is consistent with the first proposed mechanism to the extent that the post-conflict perception of safety is larger in areas that experienced worse violence. Moreover, consistent with the second mechanism, elsewhere we show that the ceasefire improved the quantity and quality of education in FARC-affected areas (Prem et al., 2021b) and that it dynamized the creation of businesses and increased employment (Bernal et al., 2022). Clearly, while better children's education and higher expected income and labor market opportunities (especially for women) may as well reduce fertility, our findings suggest that ultimately the positive fertility effect dominated during our sample period, which lapses over four post-ceasefire years. ${ }^{3}$

In turn, in the context of the end of a low-intensity conflict, fought for a very long period and in specific peripheral regions with low state presence, we find no support for a number of alternative mechanisms previously explored in the literature and related to the economic rebound experienced after short but intense episodes of violence or natural disasters. First, previous literature has shown that parents may be inclined to replace the children lost during conflict (Schindler and Bruck, 2011; Rutayisire, 2014; Kraehnert et al., 2018; Heuveline and Poch, 2007). However, we find no significant heterogeneous effects in municipalities with higher levels of infant mortality prior to the start of the ceasefire. Indeed, in such places, child replacement would have been more likely to occur.

Second, conflict termination could restore the functioning of marriage markets that violence disrupted. Indeed, it has been shown that violence generates a shortage of eligible men (De Walque, 2006); delays marriage decisions (Shemyakina, 2009; Curlin et al., 1976); and increases the incidence of divorce (Agadjanian and Prata, 2002; Woldemicael, 2008). ${ }^{4}$ Nonetheless, we find that the share of births from women who cohabit with their partner is not differentially affected by the ceasefire, and when looking at census-level data prior to and after the ceasefire, we find no differential change in the rate of married individuals in treated municipalities. In addition, as mentioned, the documented post-ceasefire dif-

\footnotetext{
${ }^{3}$ The proposed mechanisms are also consistent with the documented increase in the adoption of contraceptive methods as a result of conflict in several contexts, including the Colombian civil war (Casey and Tshipamba, 2017; Orach et al., 2015; Casey et al., 2013; Williams et al., 2012; Svallfors, 2021a; Potter et al., 1976), as well as with the evidence on the negative relationship between economic uncertainty and fertility (Chabé-Ferret and Gobbi, 2021; Clark and Lepinteur, 2020; Ayllón, 2019; Busetta et al., 2019; Chevalier and Marie, 2017; Sommer, 2016; Schneider, 2015; Hondroyiannis, 2010; Modena et al., 2014; Ananat et al., 2013; De la Rica and Iza, 2005; Adsera, 2004).

${ }^{4}$ The disruption of marriage markets can in turn feedback into the persistence and intensity of conflict, as it pushes young men to join the insurgency (Rexer, 2022).
} 
ferential fertility increase is not driven by the age windows at which most women marry in Colombia.

Third, the end of conflict may trigger the restoration of healthcare infrastructure and increase access to maternal, sexual, and reproductive health (Chukwuma and EkhatorMobayode, 2019; Gopalan et al., 2017; Tunçalp et al., 2015; Chi et al., 2015; Price and Bohara, 2013). We examine a range of variables related to health infrastructure and the operation of the health sector (such as the rate of birth attended by a qualified professional and the number of ambulances and hospital beds) and find that, by and large, they do not significantly improve after the ceasefire in treated municipalities.

Fourth, large violence drops may mechanically increase fertility rates if newborns die or their health deteriorates because of conflict. Indeed, a strand of the literature has found that intrauterine exposure to violence (Mansour and Rees, 2012; Eskenazi et al., 2007; Camacho, 2008; Leon, 2012; Brown, 2018) or to natural disasters (Aizer et al., 2016; Almond et al., 2018; Khashan et al., 2008) increases fetal mortality as well as the incidence of low birth weight. However, perhaps because of the low intensity and long duration of the Colombian conflict, we find no evidence that outcomes such as weight at birth or the mortality rate of newborns changed differentially after the ceasefire in areas more exposed to FARC violence.

Fifth, the differential fertility surge could be driven by the behavior of women who migrate to the newly peaceful areas after FARC stops exerting violence, rather than reflecting the choice of the women who actually experienced the violence during the preceding years. We find no evidence of this alternative explanation, as we document no differential post-agreement incoming migration neither of (returning) conflict-driven internal refugees nor of the general population. Moreover, we show that the share of births from mothers with different characteristics is also unaffected by the ceasefire, suggesting that any potential selective migration due to the reduction in violence did not change the demographic composition of mothers.

Finally, civil wars are often fought by insurgent groups that enforce strict rules about romantic partners and fertility, in which case the behavior of demobilized ex-combatants may drive post-conflict baby booms. While we find empirical support for the existence of a baby boom within areas where former combatants settled after the peace agreement, we also show that this does not drive the estimates that we obtain for the entire country.

It is worth noting that a different strand of the literature highlights mechanisms consistent with the opposite effect of peace on fertility, namely that fertility rates are higher in 
periods of high violence (Akseer et al., 2020; Castro Torres and Urdinola, 2019; Urdal and Che, 2013; Kreif et al., 2022) and decrease after the end of the conflict (Clifford et al., 2010). For instance, inasmuch as violence is negatively associated with economic development, parents may have more children in the context of high levels of violence under the expectation that children may provide care and economic aid to their parents down the road (Verwimp and Bavel, 2005). Similarly, in violent environments, couples may hoard more births than desired if they anticipate that some of their children may die (Schultz, 1997). Moreover, the documented excess of gender-based violence in conflict-prone areas (Svallfors, 2021b; Kreft, 2020; Wirtz et al., 2014) reduces access to contraception and hurts reproductive autonomy (Svallfors and Billingsley, 2019; Svallfors, 2021a).

The above discussion shows how our paper contributes to the extensive literature on the intersection of development economics, health, and demography on the relationship between violence -or other shocks such as natural disasters- on health outcomes in general and fertility dynamics in particular. Specifically, we document how violence reductions in contexts of low-intensity and long-lasting conflicts may result in differential fertility increases in conflict-affected areas and discuss the mechanisms potentially explaining such results. In other contexts such as the end of the Khmer Rouge regime in Cambodia, or the aftermath of the Rwandan genocide, the fertility rebound is explained by some of the aforementioned alternative mechanisms, respectively the increased availability of male partners as the conflict ended (De Walque, 2006) and the child replacement effect for households that lost children during the genocide (Kraehnert et al., 2018). However, as mentioned, such a rebound is far from obvious in long-lasting, low-intensity conflicts.

Moreover, this paper contributes to the growing literature that studies the consequences of conflict termination, particularly the end of the 5-decad-long conflict between FARC and the Colombian state. Other papers highlight significant unintended negative consequences of the peace agreement in terms of the security of social leaders (Prem et al., 2022b) and the dynamics of deforestation and coca cultivation (Prem et al., 2020, 2021a), as well as the positive implications of peace and demining for saving lives, human capital accumulation, and entrepreneurship (Perilla et al., 2022; Prem et al., 2021b, 2022a; Bernal et al., 2022; de Roux and Martinez, 2020). 


\section{Context}

\subsection{Colombia's internal armed conflict and the peace process}

Colombia's internal armed conflict started with the launch of two nationwide guerrilla movements in the 1960s: FARC and the National Liberation Army (ELN from the Spanish acronym). Both groups claimed to represent the rights of peasants and workers and fought with the goal of overthrowing the government to build a socialist regime. While they were initially located in a few peripheral rural areas, they have sought to expand their territorial dominance over decades. In turn, territorial contestation with government forces as well as with illegal right-wing paramilitary groups, has resulted in violence throughout a large part of the country's territory. Violence is further shaped by the scope of illegal activities that fuel the conflict. These include kidnapping, extortion, looting, and the production and trafficking of illegal drugs. Consequentially, most of the almost 9 million officially recognized victims of the conflict are from rural areas. ${ }^{5}$

In October 2012, the Colombian government and FARC started peace negotiations in Cuba. One of the most significant milestones of the process was the establishment of a unilateral permanent ceasefire by FARC on December 20, 2014. While a temporal cease of hostilities was commonly announced by FARC to observe the Christmas festivities, a permanent ceasefire was unprecedented and unexpected. FARC did so to signal to the government negotiating team its unified nation-wide command structure as well as its commitment to reaching a peace agreement. Ultimately, the ceasefire was largely met and it was replaced by the definitive bilateral ceasefire and the subsequent disarmament of FARC in mid-2016, when the final peace agreement was reached. This explains why FARC's offensive activities dropped by $98 \%$ during this period (CERAC, 2016). ${ }^{6}$ Thereafter, FARC soldiers withdrew from the guerrilla strongholds and settled in the so-called Transitory Normalization Zones of Transformation (ETCR from its Spanish acronym), where the reincorporation programs devised by the peace agreement were to be implemented.

\footnotetext{
${ }^{5}$ Source: Victims' Registry, from the Unit for the Victims Assistance and Reparation, November 2020 figure. Available from: https://www . unidadvictimas.gov.co/en (last accessed 12/05/2022).

${ }^{6}$ While for our purposes the ceasefire is the most important regime change for the reasons mentioned, it was not the only milestone of the peace process. Others include the announcement of the peace negotiations in October 2012, partial agreements reached over the course of the negotiation on specific items of the negotiation agenda, the actual signature of the agreement in September 2016, its public rejection after a national referendum in October that year, and its definitive ratification by Congress in December. While we show empirical support for our choice of time heterogeneity, others have shown that for outcomes such as the demand for agricultural credit, the period given by the implementation of the agreement is more relevant (de Roux and Martinez, 2020).
} 
To understand the dynamics of violence during our sample period Figure 1 plots the change in the incidence of different proxies of conflict-related violence before and after the start of the permanent ceasefire. There is a clear sharp decrease across all the measures.

\subsection{The Colombian health system}

Universal public health care in Colombia is a constitutional right (see articles 44 and 49). Law 100 of 1993 created the General System of Social Security in Health (SGSSS from the Spanish acronym), which introduced competition in both insurance and care provision through a managed-care model that includes both public and private health providers (Bardey and Buitrago, 2017). SGSSS aims to cover the entire population by combining a contributory regime (for patients with payment capacity) with a subsidized regime (for patients without payment capacity or else for vulnerable communities prioritized by the government). In 2019, 95 percent of the population was affiliated to the SGSSS, with about 45 percent of the patients belonging to the contributory regime and a similar figure to the subsidized regime. The residual share of the population belonged to a special regime (MinSalud, 2019). ${ }^{7}$ While, in principle, patients of both regimes have access to the same healthcare benefits, in practice, specific insurers limit access to certain benefits (Vargas et al., 2010).

Colombia's total fertility rate (TFR) was 1.82 children per woman during the period 20152020 (UN, 2019). While this figure is slightly smaller than the average of Latin America and the Caribbean (2.04), it lies close to the upper limit of the TFR range of OECD countries (from 1.4 to 1.9) (OECD, 2019). ${ }^{8}$

\section{Data}

In order to study the effect of the ceasefire on fertility rates as well as on intermediate outcomes related to the demand for health care and to health-at-birth outcomes, we constructed a municipality-year-level panel with information from multiple sources. We focus on the period from 2011 to 2018, with the ceasefire taking place in December 2014. 2011 is the first full presidential year of president Juan Manuel Santos, who successfully managed to start formal peace talks with FARC and bring them to the point of declaring

\footnotetext{
${ }^{7}$ In addition, members of the military and police forces, public teachers with a staff contract, and employees of the Colombian Petroleum Company (ECOPETROL) have special public health schemes.

${ }^{8}$ In April 2020, Colombia officially became an OECD member.
} 
a permanent ceasefire. During this period, FARC's violent dynamics are quite different than during the years before, marked by president Uribe (2002-2010)'s harsh antiinsurgent campaign that pushed FARC to retreat and reduce its violent activity. By defining the treatment during the four-year window before the ceasefire we are thus capturing the differential effect of the ceasefire on the areas that were most affected toward the end of the conflict with FARC. ${ }^{9}$ The sample includes all Colombian municipalities except the large cities (with populations of at least 200,000 people in 2010 according to projections from DANE, Colombia's statistics bureau). The resulting number of municipalities is $1,092 .{ }^{10}$ We now describe the main variables and their source. For a complete list of all the variables used in the paper, together with their source, we refer to Table A.1 in the Appendix.

\subsection{Conflict data}

To construct a measure of exposure to FARC violence before the start of the ceasefire, we use the conflict dataset originally compiled by Restrepo et al. (2003), and updated through 2019 by Universidad del Rosario. This dataset codes violent events recorded in the Noche y Niebla reports from the NGO Center for Research and Popular Education (CINEP from the Spanish acronym), which provides a detailed description of the violent event, its date of occurrence, the municipality in which it took place, the identity of the perpetrator, and the count of the victims involved in the incident. ${ }^{11}$

For our treatment variable, we focus on FARC violence rather than presence. While the latter is conceptually important, as areas controlled by FARC likely experienced a change in governance after the ceasefire, it is much more difficult to operationalize in a systematic fashion with observable actions. We thus focus on a treatment that is at least as important, namely the effect of peace on fertility in the municipalities that experienced a reduction in violence (which of course may have some overlap with those that experienced a change in power).

\footnotetext{
${ }^{9}$ It is important to highlight, however, that our results are not just an artifact of the period picked for the treatment definition. They are robust to expanding the period all the way until the start of Uribe's first term (2002).

${ }^{10}$ We drop major cities and capitals to make the sample more comparable but our results are robust to not excluding them.

${ }^{11}$ Noche y Niebla sources include 1. Press articles from more than 20 daily newspapers of both national and regional coverage. 2. Reports gathered directly by members of human rights NGOs and other organizations on the ground, such as local public ombudsmen and, particularly, the clergy (Restrepo et al., 2003). Notably, since the Catholic Church is present in even the most remote areas of Colombia, we have extensive coverage of violent events across the entire country.
} 
Specifically, to measure FARC attacks, we first created a continuous measure based on the total number of FARC attacks over 10,000 inhabitants that took place from 2011 to 2014 in a municipality. ${ }^{12}$ We standardized the continuous measure using the mean and standard deviation from the empirical distribution. While our main results will be based on this continuous treatment definition, for robustness we construct a second measure based on a dichotomous version of it. The latter would take the value of one if there was at least one violent case by FARC during the same period. Based on the latter treatment definition, 99 municipalities ( $9 \%$ of our sample) resulted as exposed to FARC violence before the ceasefire.

\subsection{Vital statistics and health care}

Civil registration and vital statistics (CRVS) systems are the most widespread source of health indicators. They are commonly used to study population dynamics, set public health goals, and conduct academic research. Colombia has a reliable vital statistics system, which registers around 95 percent of all births and 86 percent of the deaths that take place in the country (Colombia Implementation Working Group, 2018; Toro Roa et al., 2019). Vital statistics in Colombia are part of the administrative Integrated Information System of the Ministry of Health and Social Protection (SISPRO from the Spanish acronym). Using these data, we construct municipality-year level TFR as follows:

$$
\text { TFR }=5 \times \sum_{a=15-19}^{40-44} f_{a}, \quad \text { where } f_{a}=\frac{\text { Births of women in age range } a}{\text { Total women in age range } a}
$$

where $f_{a}$ is the age-specific fertility rate (ASFR) of women whose age corresponds to the five-year age group $a .{ }^{13}$ To compute it, we use the annual number of births based on the mother's municipality of residence. In addition to using the number of birth as an input to compute the TFR, we also use the birth rate (number of live births per 1,000 inhabitants) as an alternative outcome.

Annual births are in turn computed from administrative birth registration counts. Birth registration is based on a live birth certificate issued by the health professional that attends the birth. ${ }^{14}$ In the absence of a live birth certificate (for instance because the child

\footnotetext{
${ }^{12}$ Our results are robust to using longer periods for the treatment definition. See section 5.

${ }^{13}$ In particular, we focus on the following six five-year age groups: 15 to $19 ; 20$ to $24 ; 25$ to $29 ; 30$ to $34 ; 35$ to 39 ; and 40 to 44 .

${ }^{14}$ In most cases, the health professional can be a doctor, nurse, nursing assistant, or health promoter (DANE, 2012). Indigenous people have the Intercultural System of Indigenous Own Health (SISPI from the Spanish acronym) with health care facilities integrated into the General System of Social Security in Health
} 
was born in a place other than a health care facility), the birth can be registered by a civil registry servant based on a sworn statement by two witnesses present at the birth (Toro Roa et al., 2019). Colombia's statistics bureau consolidates, validates, and processes information from all birth certificates (DANE, 2012). Importantly, birth certificates also include information on mother's characteristics, namely age (as well as that of the father), number of past pregnancies, civil status, and education level.

We also use CRVS and SISPRO to construct a range of variables and indicators used to test potential mechanisms. For instance, CRVS also includes mortality data derived from vital statistics. From it, we compute a range of mortality rates using as denominator 1,000 live births. These include fetal mortality rates (fetal deaths per 1,000 known pregnancies - live births plus fetal deaths-), neonatal mortality rates (deaths occurring during the first 28 days of life), infant mortality rates (deaths under the age of 1), and under-5 mortality rates. We also construct deaths associated with acute respiratory infections (ARI) and acute diarrhoeal disease (ADD) for children under 5 years. These are two of the most common causes of child death associated with poor socioeconomic conditions which correlate with a lack of access to basic health services (Alvis-Zakzuk et al., 2018).

CRVS further includes the number of antenatal care contacts during pregnancy (WHO recommends 8 prenatal care visits WHO, 2018), as well as outcomes associated with pregnancy health such as the incidence of low birth weight (LBW, defined as less than 2,500 grams), preterm births (less than 37 weeks of gestation), the APGAR test, and C-sections. In turn, from SISPRO we obtain information related to the demand for health services that are covered by the mandatory health insurance system.

\subsection{Municipalities characteristics}

We complement these data with a large set of municipality characteristics from different sources. The primary source is the annual panel of Colombian municipalities, maintained and hosted by the Center for Economic Development Studies (CEDE from the Spanish acronym, Acevedo et al., 2014). We obtained the measures of the share of people leaving in rural areas, the distance of each municipality to the department's capital, and a multidimensional poverty index.

We also use proxies of the violent presence of illegal armed groups other than FARC in a municipality (from Prem et al., 2022b), an indicator of the municipalities selected to host the ETCR (from the Agency for Reincorporation and Normalization), data on landmines vic(See https://rb.gy/xfcck1 (last accessed 12/05/2022)). 
tims (from the Office of the High Commissioner for Peace in Colombia), information of the number of children recruited by illegal groups (from Centro Nacional de Memoria Histórica - $\mathrm{CNMH}$, Colombia's Truth Commission) and information on internal forced displacement (from Colombia's Victims' Registry).

Finally, we use administrative databases other than those described in the previous subsection, including the 2005 and 2018 population censuses (DANE, 2005, 2020) and information on the health infrastructure per municipality and per year (from the Special Register of Health Service Providers, REPS).

Table A.2 in the Appendix reports pre-ceasefire descriptive statistics of the main variables. During that period there were, on average, 1.6 live births per woman and the highest ASFR was that of women in the 20 to 24-year-old window. In turn, Table A.3 reports the pre-ceasefire differences between treatment and control municipalities across all the main variables. Municipalities that experienced FARC violence were on average different from non-exposed areas in several characteristics. These level differences, however, do not prevent us from estimating the causal effect of the ceasefire on fertility rates and other intermediate outcomes and potential mechanisms, as we explain in the next section.

\section{Empirical strategy}

\subsection{Main specification}

To estimate the effect of the end of the conflict between the Colombian state and the FARC guerrilla, we exploit two sources of variation. First, the temporal variation is given by the timing of the permanent ceasefire announced by FARC on the 20th of December 2014. Second, the cross-sectional variation comes from the level of pre-ceasefire FARC violence across municipalities. More formally, using the subindex $m$ to denote municipalities, $d$ to denote departments, and $t$ to denote years, we estimate the following difference-indifferences specification:

$$
y_{m d t}=\alpha_{m}+\delta_{d t}+\beta\left(\text { Cease }_{t} \times \text { FARC }_{m}\right)+\sum_{c \in X_{m}} \gamma^{\prime} c \times \text { Cease }_{t}+\varepsilon_{m d t}
$$

where $y_{m d t}$ is the TFR in municipality $m$, located in department $d$, during year $t . \alpha_{m}$ and $\delta_{d t}$ are municipal and department-time fixed effects that capture any time-invariant municipal-level heterogeneity and any aggregate department-level time shock, respectively. Cease $e_{t}$ is a dummy that equals one after the start of the permanent ceasefire (hence 
2015 onward) and $F A R C_{m}$ measures pre-ceasefire exposure to FARC violence. ${ }^{15} X_{m}$ are municipality characteristics measured before the ceasefire. We interact these characteristics with the Cease $t$ dummy to account for differential changes after the ceasefire in our outcome of interest, driven by these municipality features. Finally, $\varepsilon_{m d t}$ is the error term clustered at the municipality level. ${ }^{16}$ Our coefficient of interest, $\beta$, captures the differential change in the TFR after the start of the ceasefire relative to before, in municipalities more exposed to FARC violence relative to those less exposed to it.

Throughout the paper, all regressions are weighted by the number of live births prior to the ceasefire (from 2011 to 2014) for each age group. We do so based on the mother's municipality of residence. This weighting procedure assigns more importance to municipalities that traditionally contribute more to fertility rates in the country, thus minimizing the role of atypical fertility rates in small municipalities. Moreover, for outcomes based on averages of individual births, this procedure gives equal importance to each newborn in the sample. As robustness, however, we also consider other weighting variables such as the total population in 2014 and the total number of women in that same year. We also show that the unweighted estimates are very similar to the weighted ones.

\subsection{Identifying assumption}

The main assumption behind the difference-in-differences model is that, in the absence of the ceasefire, the TFR in municipalities more exposed to FARC violence would have evolved similarly to those in municipalities less exposed. The validity of this parallel trends assumption can be partially assessed by estimating the following dynamic version of the main specification:

$$
y_{m d t}=\alpha_{m}+\delta_{d t}+\sum_{j \in T} \beta_{j}\left(F A R C_{m} \times \delta_{j}\right)+\sum_{c \in X_{m}} \gamma^{\prime} c \times \text { Cease }_{t}+\varepsilon_{m d t}
$$

where $T$ includes all years of our sample period except 2014, which is the year right before the ceasefire. Therefore the parameters $\beta_{j}$ can be interpreted as the difference in the TFR in municipalities more exposed to FARC attacks compared to municipalities less exposed, in year $j$ relative to the year right before the ceasefire started.

\footnotetext{
${ }^{15}$ As discussed in section 2 , we take the ceasefire as the main temporal shock that can affect fertility choices. While in our dynamic specifications we are more agnostic about this choice, the semi-parametric analysis ultimately confirms it.

${ }^{16}$ We also show the robustness to controlling for spatial and first-order time correlation (see Conley, 1999, Conley, 2016).
} 


\subsection{Disentangling potential mechanisms}

We augment the main specification in equation (2) to test for heterogeneous effects by municipal-level characteristics. We do so by adding a third interaction term. Specifically, let the municipality characteristic $Z_{m}$ (measured before the ceasefire, except for the ETCR) be a potential mechanism of interest. We estimate:

$$
\begin{array}{r}
y_{m d t}=\alpha_{m}+\delta_{d t}+\beta_{1}\left(\text { Cease }_{t} \times \text { FARC }_{m} \times Z_{m}\right)+\beta_{2}\left(\text { Cease }_{t} \times Z_{m}\right) \\
+\beta_{3}\left(\text { FARC }_{m} \times Z_{m}\right)+\beta_{4}\left(\text { FARC }_{m} \times \text { Cease }_{t}\right)+\sum_{c \in X_{m}} \gamma^{\prime} c \times \text { Cease }_{t}+\varepsilon_{m d t}
\end{array}
$$

Our coefficient of interest, $\beta_{1}$, captures the differential change in the outcome variable in places more exposed to FARC attacks and with municipality characteristic $Z_{m}$. In addition, to interpret this coefficient in a causal way, a similar "parallel trends" assumption has to hold but for municipalities both more exposed to FARC violence prior to the ceasefire and with municipality characteristics $Z_{m}$. Hence, to partially assess the validity of this assumption we estimate a version of equation (3) but for the triple interaction.

Using the above specifications, we estimate the differential impact of the permanent ceasefire on the TFR in areas previously exposed to FARC violence (equation 2), the dynamic evolution of this effect (equation 3), and heterogeneous effects given by an array of municipality characteristics (equation 4). The next section reports the estimated results, together with a large set of robustness checks.

\section{Results}

\subsection{Main results and robustness}

Table 1 reports the empirical estimates of equation (2). Columns 1 to 4 report estimated coefficients on the baseline sample and Columns 5 to 8 refine, following different techniques, the control group to municipalities more similar to those affected by FARC. We do so in order to address a potential threat to identification, namely that municipalities exposed to FARC violence are different from not-exposed areas along with unobserved characteristics that may have varied after 2014 for reasons other than the start of the ceasefire.

Within the baseline sample, Column 1 includes municipality and year fixed effects, Column 2 includes municipality and department $\times$ year fixed effects, and Column 3 builds 
on the specification of Column 2 and further controls for differential changes in the TFR after the ceasefire, parametrized by several pre-ceasefire municipality characteristics. ${ }^{17}$ Finally, in Column 4, we address the fact that, after the ceasefire, other armed groups took advantage of the vacuum of power in former FARC strongholds to expand their territorial presence (Prem et al., 2022b), thus increasing illegal activities. To that end, we include an additional set of controls that capture differential changes in fertility rates parametrized by variables associated with the incidence of violence and illegal activities. ${ }^{18}$ Additionally, Table A.4 of the Appendix further includes municipality-specific trends in the specification without controls (Column 1) and with the baseline controls (Column 2).

Our estimates, which are robust in terms of magnitude and significance to estimating the more demanding models of Columns 2 to 4 , suggest that a one-standard-deviation increase in the number of FARC attacks per 10,000 inhabitants over the period 2011-2014 caused a differential increase in the TFR of 0.04 births per woman in their reproductive period (15 to 44 years old) after the ceasefire. This effect is statistically significant and equivalent to 0.07 standard deviations $(=0.04 / 0.598)$, or to 2.6 percent of the TFR sample mean $(=0.04 / 1.55) .{ }^{19}$ When we add municipal-level trends (Appendix Table A.4) the estimates are still significant but smaller in magnitude.

The estimated effect of the ceasefire on fertility rates is robust to refining the set of comparison municipalities in different ways. In Column 5, the control group is composed only of municipalities that, over the period 2011-2014, experienced violence perpetrated by other illegal armed groups. This is important to ensure that our findings do not just reflect a differential trend in conflict-affected vis-à-vis peaceful areas. Alternatively, to avoid potential contamination of the control group, Column 6 excludes all municipalities that share a border with a treated (FARC-affected) area. In addition, following Crump et al. (2009), in Column 7, we truncate the sample in order to increase the overlap of treated and control municipalities in terms of various municipal characteristics. In the three cases, we find point estimates that are significant and virtually unchanged in terms of magnitude relative to our baseline specification. Finally, in Column 8, we implement a recently developed synthetic difference-in-differences estimator (Arkhangelsky et al., 2021), finding

\footnotetext{
${ }^{17}$ These include the infant mortality rate, the number of victims related to anti-personnel landmines, the share of the rural population, the distance from each municipality's centroid to its department capital, a poverty index, and the logarithm of the 2010 municipal population.

${ }^{18}$ These include the suitability to grow coca (used to produce cocaine, of which Colombia is the world's top exporter), gold suitability, and an indicator of whether the municipality witnessed any attack by another armed group during the pre-ceasefire period from 2011 to 2014.

${ }^{19}$ In square brackets, we present the p-values for standard errors control for spatial and first-order time correlation (see Conley, 1999, Conley, 2016).
} 
again similar results in terms of magnitude and significance.

Figure A.1 of the Appendix reports the dynamic version of the synthetic difference-indifferences estimate. It can be seen how, prior to the start of the ceasefire, the evolution of the TFR in FARC-exposed municipalities and in their synthetic counterpart is indistinguishable from one another. However, starting in 2015 the lines significantly diverged.

Table 2 reports the effect of the start of the permanent ceasefire on various age-specific fertility rates to explore whether the effect found for the TFR is driven by particular age brackets. We measure the ASFR in five-year age groups, covering the range of 15 to 44 . We find that a one-standard-deviation increase in the number of FARC attacks per 10,000 inhabitants over the period 2011-2014 caused a differential increase in the ASFR across the board. ${ }^{20}$ Moreover, the magnitude of the effect size -the ratio of the coefficient over the average of the dependent variable- is similar across all age groups. The highest increase is observed for the 20-24 age range, with an increase in the fertility rate of 7.9 percent of the sample mean (0.0028 additional births per woman).

Our estimates on the effect of the ceasefire on the total fertility rate are robust to additional tests that we describe next. First, while our baseline treatment definition uses the continuous per capita measure of FARC attacks over the period 2011-2014, our results are robust to using several alternative measures of exposure to FARC violence. For instance, when we use a discrete version of the treatment based on the extensive margin of FARC attacks (a measure that may also partly capture FARC presence, see section 3 for a discussion), we find that municipalities that experienced at least one attack by FARC over the period 2011-2014 witnessed a differential increase of 0.08 children per woman after the start of the ceasefire, equivalent to 5.2 percent of the TFR sample mean (see Appendix Table A.5, Columns 1 to 3). Alternatively, we rule out the possibility that our results are driven by a few outliers that experienced an unusually high number of FARC attacks prior to the ceasefire. Appendix Table A.6 reports the robustness of our baseline finding to drop from our estimation sample up to the top 8 FARC-affected municipalities. Finally, we can extend the measure of pre-ceasefire exposition to FARC violence over longer time windows, to show that the results are not an artifact of our baseline treatment definition. Specifically, we backdate our sample period to 2006 (2002), the year that marks the first year of president Alvaro Uribe's second (first) presidential term. Measuring the exposition to FARC violence during these alternative periods produces remarkably similar results, as shown in Appendix Table A.7.

\footnotetext{
${ }^{20}$ We also include in the table p-value adjusted for the false discovery rate due to multiple hypotheses testing. To do so, we follow Westfall and Young (1993) and Jones et al. (2019).
} 
Second, recall that for our baseline results we estimate equation (2) weighting the observations by the number of live births between 2011 and 2014. However, the results are very similar if we use other weighting variables such as the total population in 2014 or the female population in that same year (see Appendix Table A.8). They are also large unchanged when we estimate the unweighted counterpart, which yields the average effect of the ceasefire on the TFR across municipalities regardless of their size (see Appendix Table A.5, Columns 4 to 9).

Third, while the TFR relates to the average number of children that a woman would have over her reproductive years, an alternative relevant outcome is the birth rate. This is because women who had decided against having children because of the violence may decide to have them after the start of the ceasefire, without this decision having any effect on their lifetime fertility. Results are reported in Table A.9 of the Appendix. Based on the most demanding specification, which includes both municipality and departmentyear fixed effects, as well as differential changes parametrized by various pre-determined controls, we find that a one-standard-deviation increase in the number of FARC attacks per 10,000 inhabitants over the period 2011-2014 caused an additional 0.37 live births per 1,000 inhabitants after the start of the ceasefire. This corresponds to nearly $3.1 \%$ of the average municipality birth rate.

\subsection{Identifying assumption}

Recall that the validity of our empirical strategy relies on the assumption that, absent the ceasefire, fertility rates would have followed the same trend in treated and control municipalities. In this subsection, we show empirical evidence consistent with this assumption.

First, in Figure 2, we plot the estimated coefficients -together with the 95 percent confidence interval-obtained from estimating equation (3). The figure has the same structure of the first four columns of Table 1, which relies on the baseline sample: the estimates in Panel (a) include municipality and year fixed effects; those in Panel (b) include municipality and department $\times$ year fixed effects; Panel (c) adds to the latter specification a set of pre-ceasefire baseline controls interacted with the year fixed effects; and Panel (d) includes, in addition, controls associated with violent and illegal activities. All panels suggest that the estimated coefficients are not statistically significant before the start of the ceasefire, in fact, the point estimates are close to 0 , and the p-values for the joint significance test do not reject the null of all the pre-ceasefire coefficients being equal to zero at conventional levels. This result points to the absence of differential trends in the TFR 
before the ceasefire between municipalities more exposed to FARC violence and places that were less exposed. Moreover, the point estimates increase in magnitude and become significant after the start of the permanent ceasefire, and the magnitude increases over time. A similar conclusion can be drawn if we consider the birth rate instead of the TFR (see Figure A.2 of the Appendix).

We also study the equivalent dynamics for the specifications that define the exposure-toFARC treatment over different pre-ceasefire periods, as well as for the case of each ASFR. The former is reported in Figure A.3 and the latter in Figure A.4, both in the Appendix. The results confirm the absence of pre-trends and the increasing post-ceasefire dynamics regardless of the period used to define exposure and in all age brackets.

Second, following Muralidharan and Prakash (2017), we conduct a more parametric test for the existence of differential linear pre-trends between 2011 and 2014. We do so by interacting a linear trend with our measure of exposure to FARC violence, and testing the significance of the associated coefficient before the ceasefire. ${ }^{21}$ The results are reported in Panel A of Table A.10 in the Appendix, and show no evidence of differential trends before the ceasefire, neither for the TFR nor for most of the ASFR.

Third, we perform a placebo exercise in which we estimate the main specification (equation 2) limited to the pre-ceasefire period (2011-2014), and use as placebo ceasefire a series of dummies that equal 1 starting each year from 2012 to 2014. The results are shown in Tables A.11, A.12, and A.13 of the Appendix for placebo treatment years 2012, 2013, and 2014 respectively. We find that there is no differential change neither in the TFR nor in any of the ASFR in areas more exposed to FARC attacks relative to other areas. Again, these results are consistent with the absence of differential pre-trends before the ceasefire.

Finally, while our baseline sample period starts in 2011, we find no differential pre-trends once we add more pre-ceasefire years. Appendix Figure A.5 shows the non-parametric estimates extending the start year of the sample period 4 years, from 2011 to $2007 .{ }^{22}$ The absence of any differential pre-trend gives extra support for our empirical design. ${ }^{23}$ It also supports our choice of the December 2014 permanent ceasefire as the main temporal treatment rather than any event taking place prior to it, including the start of the peace negotiations or some of the partial agreements reached early on during the peace talks.

\footnotetext{
${ }^{21}$ The specification we run is $y_{m d t}=\alpha_{m}+\lambda_{d t}+\beta\left(F A R C_{m} \times\right.$ Trend $\left._{t}\right)+\epsilon_{m d t}$, where Trend $t$ is a linear trend and we restrict the sample to the years 2011 to 2014 . Our parameter of interest, $\beta$, shows whether there are differential linear trends in municipalities more exposed to FARC's violence.

${ }^{22}$ Moreover, Columns 3 and 4 of Appendix Table A.4 show that the estimates from this extended sample are also robust to adding municipal-level trends.

${ }^{23}$ Unfortunately, we cannot estimate this extended version for the other outcomes due to data availability.
} 
Taken together, this set of results largely validates our empirical strategy and provides credibility to our main result, namely that FARC's permanent ceasefire triggered a differential increase in fertility rates in treated areas.

\section{Mechanisms}

This section explores the empirical relevance of several potential mechanisms through which the start of the ceasefire differentially increased the TFR and ASFR in municipalities previously affected by FARC violence. Understanding the potential mechanisms is essential for developing policy responses to take advantage of the ceasefire's positive effects, as well as counteracting its potentially adverse consequences.

\subsection{The reduction in victimization and the perception of security}

Illegal armed groups engage in violent coercion to influence various domains of the local life in the communities where they are present. By doing so, they influence politics, economics, social relations, and even people's private life. In the specific case of the Colombian conflict, the available evidence suggests that illegal armed actors often regulate mobility, establishing rules about when civilians could be outside their homes, travel, or cross a municipal border. This largely limits the extent of social interactions within conflict-affected communities (Arjona, 2016). In addition, territorial contestation often entails the use of violence (selective or collective) against civilians. Thus, for reasons either related to territorial dispute or territorial control, people living in conflict-affected areas likely face a non-negligible risk of victimization (Kalyvas, 2006). Colombia's long conflict is not the exception. It resulted in almost 9 million victims registered with the government, about 17 percent of the country's population. ${ }^{24}$

In such contexts of uncertainty and deprivation, parents may be less willing to take actions that have specific long-term consequences, such as fertility. In turn, the end of conflict may trigger generalized feelings of improved security and optimism, which drive fertility choices, especially in the areas more affected by violence. We assess the empirical relevance of this potential mechanism in different ways. First, we estimate equation (4) to explore if there are any heterogeneous effects in municipalities that suffered exceptionally high levels of violence prior to the ceasefire. We do so by looking at differential effects

\footnotetext{
${ }^{24}$ The Victim's Registry is a mechanism created by the government to assist and provide reparations to conflict victims. Its scope is only partial because the Registry's legal framework only recognizes victims as of 1st January 1985.
} 
based on episodes of the explosion of landmines, instances of internal forced displacement of civilians, and the intensity of children's recruitment by illegal armed groups. All these variables are measured prior to the ceasefire and capture different forms of conflict intensity. ${ }^{25}$

The results from these tests are reported in Columns 1 to 3 of Table 3. We find that the differential increase in fertility rates is larger in places that witnessed more landmines explosions (Column 1), in areas that expelled more internal refugees (Column 2), and in places that experienced higher child recruitment prior to the start of the ceasefire (Column 3). This is relevant because Colombia was the second country with the most accidents registered with anti-personnel landmines in 2014 (after Afghanistan), with 286 recorded casualties (Monitor, 2015). Colombia is also the second country with the largest refugee population after Palestine, ${ }^{26}$ and had one of the highest numbers of child soldiers in the world (Coalition to Stop the Use of Child Soldiers, 2008). ${ }^{27}$

Panels (a.1) to (a.3) of Figure A.6 show the dynamic difference-in-differences specification for each of these heterogeneous effects. We observe that differences prior to the ceasefire for all of them are not significant (with the exception of one year for the incidence of landmines' victims). However, after the start of the ceasefire there is a differential increase in the TFR in municipalities that had plausibly experienced higher levels of victimization (as parametrized by these variables).

Appendix Table A.14 provides additional evidence of the exacerbating role of the exposure to higher levels of FARC victimization. It shows that the effect is substantially larger in the municipalities that were exposed to the top quartile of the empirical distribution of the number of FARC attacks during the period 2011-2014. There, the increase in the TFR after the start of the ceasefire (when these extremely high violence levels disappeared) is 15.5 percent of the TFR sample mean.

In addition, we also show that in communities that were more supportive of the peace agreement with FARC, the differential fertility increase is disproportionately larger. Indeed, after a final agreement was reached in September 2016, Colombia's president asked for the citizen's validation of the agreement in a national referendum that took place on October 2 of that year. We estimate equation (4) to explore potential heterogeneous effects

\footnotetext{
${ }^{25}$ Indeed, they are not very highly correlated. All the cross-correlations are 0.2 with the except of that of landmines and forced displacement with is 0.7 .

${ }^{26}$ See https://rb.gy/jigrmh (last accessed 12/5/2022).

${ }^{27}$ Moreover, between 1960 and 2016 almost 17,000 cases of illegal child recruitment into armed groups were recorded in Colombia (CNMH, 2017). While most of these children were boys (68\%), girls were also commonly abducted by armed groups.
} 
in municipalities with a higher share of the 'Yes' vote, hence where more voters countersigned the peace agreement. The results are reported in Column 4 of Table $3{ }^{28}$

Finally, we study a period heterogeneity that is potentially informative of the proposed mechanism. In the first two years after the start of the ceasefire (2015-2016), the peace negotiations were still ongoing and FARC was still present in its strongholds. However, from 2017 onward the implementation phase of the peace agreement started and FARC troops concentrated in a few areas that were targeted to receive reincorporation programs as established by the peace agreement (called ETCR). In this sense, while the first subperiod was characterized by a large reduction in violence following the ceasefire, during the second the perception of security may have further improved due to the departure of former FARC combatants. Relatedly, the withdrawal of FARC may have changed the local norms and informal institutions in its former strongholds.

To test this temporal heterogeneity, we estimate a version of equation (2) that adds an interaction between a dummy that equals one since 2017 and the measure of high exposure to FARC violence. The results are reported in Appendix Table A.15. Focusing on the most demanding specification (Column 3), we find that the effect for the initial two years after the start of the ceasefire is 0.03 additional births per woman, and the total effect for the latter period is $0.07(0.03+0.04)$. This implies that violence reduction causes a differential fertility increase in treated municipalities that is 43 percent $(=0.03 / 0.07)$ of the effect caused by both violence reduction and the additional perception of security that the departure of FARC may have induced.

\subsection{Post conflict economic prospects}

A second mechanisms supporting our results is that, in our context, children are a normal good, so the higher expected income that followed the end of violence translated into higher fertility. ${ }^{29}$ On the one hand, Prem et al. (2021b) document that the ceasefire generated large differential improvements in a number of educational outcomes in areas formerly affected by FARC's violence, and differentially so in places with more mine victims and forced displacement prior to the ceasefire. On the other, Bernal et al. (2022) find

\footnotetext{
${ }^{28}$ As the peace referendum occurred after the ceasefire. This heterogeneous effect should be interpreted with caution.

${ }^{29}$ One unsettled debate in the economics literature is whether children are normal or inferior goods. While some argue that higher income and schooling could lower fertility (Becker and Lewis, 1973; Bleakley and Lange, 2009), especially if the growing labor market opportunities generate a differential demand for female labor (Schultz, 1985; Jensen, 2012; Heath and Mobarak, 2015); other find evidence that children are, by and large, normal goods (Lindo, 2010; Lovenheim and Mumford, 2013; Black et al., 2013).
} 
that the ceasefire triggered a differential creation in FARC-affected areas of new (formal and informal) firms across all economic sectors, and increased local employment levels. ${ }^{30}$ Consistently, de Roux and Martinez (2020) find that in these areas the peace agreement increased the demand for agricultural credits.

Taken together, this suggests that, in addition to becoming a safer place to raise children, municipalities previously exposed to FARC violence also became a better place to reap the returns from schooling with better economic opportunities. We argue that this evidence helps explaining the differential increase in fertility that we document.

\subsection{Child replacement}

A second potential reason behind the observed post-ceasefire dynamics in fertility rates in treated and control municipalities has to do with the child replacement theory. In other contexts, it has been documented how parents may want to replace children who were lost as a result of the conflict (Schindler and Bruck, 2011; Rutayisire, 2014; Kraehnert et al., 2018; Heuveline and Poch, 2007).

While this theory generally refers to the behavior after events that lead to very high levels of child mortality in relatively short periods, rather than to low-intensity and long-lasting conflicts such as Colombia's, we test it by estimating equation (4) to explore if there are any heterogeneous effects in municipalities where infant mortality was higher prior to the start of the ceasefire. ${ }^{31}$ Indeed, in such places child replacement would have been more likely to occur. Column 4 of Table 3 shows this is not the case. Further, Panel (a.4) of Figure A.6 shows that this differential effect was zero for all the years before the start of the ceasefire, as well as afterwards. Hence, we find no empirical support for this mechanism. ${ }^{32}$

\footnotetext{
${ }^{30}$ The fact that the positive effect of the ceasefire on firm creation is only short-lasting (2015 and 2016) suggests that the proposed economic optimism mechanism does not fully explain the persistent differential fertility decrease. Another mechanism, such as the security prospects discussed in the previous subsection, are also relevant.

${ }^{31}$ This is defined as the number of deaths of children under 1 year per 1,000 live births, between 2011 and 2014.

${ }^{32}$ However, this should be interpreted cautiously given the long nature of the Colombian conflict. If households are willing to replace children who died several years ago, this test will not be enough as child mortality rates might differ over time.
} 


\subsection{Marriage markets}

There is evidence that conflict may disrupt marriage markets, as it generates a shortage of eligible men (De Walque, 2006); delays marriage decisions (Shemyakina, 2009; Curlin et al., 1976); and increases the incidence of divorce (Agadjanian and Prata, 2002; Woldemicael, 2008). In turn, conflict termination could restore the functioning of these disrupted markets and therefore have a positive effect on fertility.

Our assessment of this potential mechanism is threefold. First, we test whether the places that were more affected by FARC violence witnessed after the ceasefire a differential increase in the share of births from mothers cohabiting with their partner (whether or not formally married). The results are reported in Table A.16. In Column 1, we find that this effect is indeed positive, but rather small ( 0.2 percent of the variable's mean) and not statistically significant. ${ }^{33}$

Second, we explore whether there was a differential increase in the rate of married individuals in FARC-affected areas after the start of the ceasefire. To that end, we estimate a version of equation (2) using as a dependent variable the census-based proportion of married (or cohabiting with a partner) individuals between 18 and 49 years of age. ${ }^{34}$ In Columns 2 to 7 of Table A.16, we find no differential change in the rate of married or cohabiting individuals in treated municipalities. ${ }^{35}$

Third, and more qualitatively, we use data from MinSalud and Profamilia (2017) to estimate that the median age at which women marry or start cohabiting in Colombia is 21.4 years. However, recall from Table 2 that the differential increase in the TFR in treated municipalities is not driven by the 20-24 age window (nor by any specific age bracket for that matter). Overall, we conclude that the empirical evidence for this alternative mechanism is, at best, very weak.

\footnotetext{
${ }^{33}$ Relatedly, in Appendix Table A.17, we show that the ceasefire did not have a differential effect on the share of births from mothers with other characteristics likely related to this mechanism, such as first time mothers (Columns 1 to 5) and mothers with different education levels (Columns 6 to 8).

${ }^{34}$ Limited by the census years, this regression uses only two years of data: one prior to the start of ceasefire (the 2005 census) and one afterwards (the 2018 census). Hence, the dynamic specification cannot be estimated for this outcome.

${ }^{35}$ One potential caveat of using two census cross-sections for this analysis is that the ex-post minimum detectable effect (MDE) is larger relative to that of our main analysis. Specifically, the ex-post MDE of Column 2 is 0.26 standard deviations, five times larger than that of column 1 of Table 1.
} 


\subsection{Healthcare delivery systems}

Fertility rates may have differentially increased in treated municipalities due to a proportionally better improvement in the quality of health services in these areas relative to places less exposed to FARC violence. This may be the case, for instance, if post-conflict investment in public goods and basic services targeted former FARC strongholds more than other areas. If so, this may have resulted in increased access to maternal, sexual, and reproductive health.

We test this hypothesis by estimating equation (2), examining the dynamics of a range of variables related to health infrastructure and the functioning of the health sector before and after the start of the ceasefire and in treated municipalities relative to the control. The results are reported in Table 4. Column 1 looks at the number of prenatal care visits and finds a statistically significant differential increase of 0.03 visits in treated municipalities after the start of the ceasefire, but only when the baseline controls are included (Panel B). Moreover, this effect is very small, equivalent to 0.5 percent of the mean. Column 2 considers the proportion of births attended by a healthcare professional or a traditional midwife. The lack of a significant effect rules out that the observed increase in the TFR is explained by the behavior of formal birth and registration channels rather than by an actual differential fertility increase. ${ }^{36}$

Further, Columns 3 to 6 examine variables related to health services and infrastructure (normalized by 1,000 inhabitants). We find that, after adding the baseline controls, the ceasefire did not translate into a significant differential improvement in the number of ambulances, the number of maternal therapeutic support, the number of hospital beds, or the number of hospital wards in treated municipalities.

In addition, Figure A.7 reports the dynamic non-parametric estimates for these outcomes, confirming graphically that most of them do not react to the ceasefire by changing differentially in treated municipalities. If anything, the availability of some healthcare services might have differentially declined. ${ }^{37}$

The lack of empirical validity of this mechanism is probably due to the fact that longlasting, low-intensity conflicts such as Colombia's are less destructive of key social infrastructure and thus less disruptive of basic services such as education and health. For

\footnotetext{
${ }^{36}$ In fact, as reported in Table A.2, the proportion of births attended by healthcare professionals was already 97 percent before the ceasefire.

${ }^{37}$ The parametric test for differential pre-trends is presented in Table A.10 and the placebo tests are presented in Tables A.11, A.12, and A.13. In both cases, we do not find evidence of differential pre-trends.
} 
instance, while there were cases in which health professionals were caught in the middle of conflict, they were usually allowed to work (Arjona, 2016). Moreover, any service disruption may take a long time to overcome, while our post-ceasefire sample period only lasts four years. ${ }^{38}$

\subsection{Child health improvement}

Related to the previous mechanism, conflict affects the health of existing children as well as that of newborns (Mansour and Rees, 2012; Leon, 2012; Camacho, 2008). If so, then large violence drops may mechanically increase fertility rates. Moreover, improvements in the health of children may increase the returns of fertility.

We test the empirical relevance of this potential mechanism by looking at the extent to which the ceasefire differentially affected the survival of children, an outcome typically associated with better health services. Specifically, we estimate equation (2) on fetal mortality, the neonatal mortality rate, infant mortality rate, and under-5 mortality rate. For the latter outcome, we distinguish between the overall mortality rate, the mortality rate due to acute diarrhea disease (ADD), and that due to acute respiratory infection (ARI). ADD and ARI are two of the most common underlying causes of death for children under the age of 5 . The results are reported in Table 5. Perhaps owing to the low intensity and long duration of the conflict, we find no significant differential change in any of the mortality rates in treated municipalities after the start of the ceasefire. Figure A.9 reports the non-parametric estimates for these outcomes, confirming graphically that neither of them presented differential pre-trends prior to the ceasefire, and that most of them do not react to the ceasefire by changing differentially in treated municipalities. ${ }^{39}$

A second channel through which this mechanism may operate is through improvements in the health conditions of newborns. For instance, if the reduction in violence results in mothers experiencing less stress, or else if the age composition of mothers changed in treated municipalities, then fertility may increase via better health outcomes for babies at birth. Table 6 shows the results of estimating the main specification (equation 2) on classic indicators of newborn health. We find no significant differential effect of the ceasefire on low birth weight (LBW, defined as less than 2,500 grams at birth), on the 1 or 5 minutes

\footnotetext{
${ }^{38}$ Note that, while there are a couple of negative and significant estimates in Table 4, specifically in the specification that adds no controls (Panel A), in these cases the direction of the coefficients go against the potential relevance of this channel.

${ }^{39}$ The parametric test for differential pre-trends is presented in Table A.10, and the placebo tests are presented in Tables A.11, A.12, and A.13. In both cases, we do not find evidence of differential pre-trends.
} 
APGAR, on preterm births (defined as births taking place before week 37 of pregnancy), or on the share of births through C-section. In turn, Figure A.10 shows that there are no differential pre-trends or post-ceasefire effects for most of these outcomes. ${ }^{40}$

\subsection{Selective migration}

Instead of being driven by the renewed optimism and sense of safety of the households that were exposed to FARC's violence prior to the start of the ceasefire, the differential increase in fertility could be driven by the arrival of migrants coming from other parts of the country. On the one hand, once FARC ceases to be a threat, formerly displaced households may return to their land. On the other, the new economic opportunities generated by the post-ceasefire entrepreneurship dynamics (Bernal et al., 2022) could attract economic migrants.

In Table 7, we test the empirical relevance of this alternative explanation. First, using our most demanding specification, we show that the start of the ceasefire did not translate into a differential rate of formerly displaced returning households. The point estimate is actually very small when compared with the sample mean (Column 1$) \cdot{ }^{41}$

Second, we look at the 2018 population census (the first after 2005) and show that, in the cross-section, our measure of FARC exposure is not correlated with the arrival of migrants, neither in the past five years (Column 2) nor in the last 12 months (Column 3). Moreover, we find similar results when splitting the population into those younger or older than 30 years old (see Columns 4 to 7).

Finally, even if there was some selective migration as a consequence of the ceasefire (that is not being captured by the above tests), it would have likely changed the composition of women giving birth in terms of their socio-demographic composition. However, as mentioned, Appendix Table A.17 (and Figure A.8) shows that the ceasefire produced no differential change in the share of births from first-time mothers or from mothers with different educational levels. Overall, the evidence suggests that migration is not a likely driver of our findings.

\footnotetext{
${ }^{40}$ The parametric test for differential pre-trends is presented in Table A.10, and the placebo tests are presented in Tables A.11, A.12, and A.13. In both cases, we do not find evidence of differential pre-trends.

${ }^{41}$ Note that this is a reliable figure because it comes from the official Victims' Registry of the Colombian government (RUV from the Spanish acronym). Internal refugee's as well as other types of victims have incentives to register in order to get reparations and other benefits from the government.
} 


\subsection{Changes in the fertility of ex-combatants}

The final mechanism that we consider is related to post-ceasefire changes in the fertility of former FARC soldiers. As with many other insurgencies, evidence suggests that FARC interfered in the private lives of their members, prohibiting romantic relationships and interrupting pregnancies to avoid having small children in their camps (Arjona and Kalyvas, 2008). Several anecdotal accounts suggest that, after the start of the ceasefire, the possibility of raising their children encouraged some FARC members to have babies. ${ }^{42}$ This could, at least partially, explain our findings.

We test this potential mechanism by estimating equation (4) to look at heterogeneous effects in the municipalities in which FARC concentrated on receiving reincorporation programs and benefits (the ETCR). This indicator, however, only takes value one since the ETCR actually became binding, in 2017; so it varies both in the cross-section and over time. In this sense, the coefficient of the triple interaction between the ceasefire period dummy, the FARC exposure measure, and the ETCR dummy captures the differential fertility change in FARC-affected areas that became ETCR from 2017 onward, and the pre-2017 change in such places is picked up by the double interactions that saturate the regression model.

The results are reported in Column 5 of Table 3. Note that the coefficient associated with the interaction between the FARC-affected areas and the ceasefire period is still significant and only slightly smaller in magnitude than the baseline estimate ( 0.034 versus 0.042 as reported in Table 1). However, the coefficient associated with the triple interaction is almost four times as large. This suggests that while FARC ex-combatants indeed seem to have experienced a large baby boom after their demobilization, this phenomenon can only explain a rather small proportion of the documented average effect for the entire country. Moreover, Panel (a.5) of Figure A.6 reports the dynamic estimates of this heterogeneity. The figure shows no differential TFR pre-trends in treated municipalities before the ceasefire and during the first two years after its enactment. However, starting in 2017, there is a small -albeit no significant-differential increase in FARC areas assigned to ETCR.

\footnotetext{
${ }^{42}$ See https://rb.gy/j2a3pw, https://rb.gy/2pb645, and https://rb.gy/9mcsiw (last accessed $12 / 13 / 2022)$.
} 


\section{Conclusion}

This paper contributes to the intersection of demography, health, and economics to study a policy-relevant research question: What is the short-term effect of the end of a longlasting, low-intensity civil conflict on fertility? While we study the case of the recent peace agreement between the Colombian government and the FARC insurgency, this research question is potentially very relevant in other contexts as well. Indeed, Fearon (2004) documents that even in the context of a declining civil war incidence since the end of the Cold War, the average duration of internal conflicts has steadily increased over time. As of today, there are several other active long-lasting low-intensity conflicts, such as those of the Philippines, Chad, and Sudan (Pettersson et al., 2021; Harbom et al., 2008).

To answer this question, we exploit the temporal variation given by the permanent ceasefire declared by FARC in December 2014, as well as the cross-sectional variation given by the pre-ceasefire exposure to FARC's violence. We find that a one-standard-deviation increase in the number of FARC attacks per 10,000 inhabitants over the period 2011-2014 caused a statistically significant differential increase of 0.04 births per woman after the start of the ceasefire, equivalent to a 2.6 percent of the average total fertility rate. Moreover, an effect of similar size ( 2 to 4 percent of the average rate) is also present across a wide range of age-specific fertility rates, from 15 to 44 years.

This relative baby boom took place in a general context of declining fertility rates in Colombia. Thus, rather than an absolute increase in fertility, it represents a smaller fertility reduction in violence-affected areas during the post-ceasefire period.

We also shed light on the underlying mechanisms that explain the differential fertility increase in the violence-affected municipality after the start of the ceasefire. Unlike the instances in which fertility is shown to increase during violent periods, the positive postconflict fertility response documented in this paper is not concomitant to the deterioration of newborn outcomes. We also rule out a number of the mechanisms traditionally highlighted by the literature to explain the observed baby booms observed after the end of high-intensity and short conflicts or following natural disasters. These include the replacement of lost children, the recovery of marriage markets, and improved health infrastructure and services. Instead, we find supporting evidence favoring a less studied mechanism: Our results are consistent with a differential fertility surge driven by the generalized perception of security and by the economic optimism resulting from the positive effect of the ceasefire and the subsequent peace agreement on educational outcomes and on firm dynamics. 
Our findings, therefore, shed light on the broader question of how peaceful environments shape household decisions. While conflicts are aggregate shocks -and thus have the potential to modify several socio-economic determinants of fertility-we document that the main driver of the observed relative baby boom is the improved perception of economic security: Families are more willing to have children when they witness improvements in the environmental conditions that favor their nurture and development. Indeed, in addition to decreasing violence levels -and largely due to that- the Colombian ceasefire was followed by large short-term improvements in a range of educational outcomes and in the creation of new firms, as documented by Prem et al. (2021b) and Bernal et al. (2022), respectively. A safer environment where the returns to education can be harvested in the long run in favor of more productive citizens and there are better economic opportunities may naturally shape fertility choices. This is in line with the literature that documents a negative aggregate relationship between economic insecurity (triggered for instance by a large recession) and fertility (Schneider, 2015; Ananat et al., 2013), and with the literature about the same sort of relationship between household-specific income uncertainty and fertility choices (Sommer, 2016). This paper documents that an aggregate positive shock (the end of a conflict) mitigates the secular fertility reduction of exposed areas.

Clearly, however, the extent to which differential fertility increases are able to generate better outcomes down the road also depends on the role of local and federal governments in consolidating instances of early childhood stimulation programs that may reduce externalizing behaviors and boost socio-emotional skills (Walker et al., 2011; Attanasio et al., 2016). This is also key to breaking the current epidemic of violence that sieges Latin America and the Caribbean.

\section{References}

Acevedo, K., Bornacelly Olivella, I. D., et al. (2014). Panel municipal del cede.

Adsera, A. (2004). Changing fertility rates in developed countries: The impact of labor market institutions. Journal of Population Economics, 17(1):17-43.

Agadjanian, V. and Prata, N. (2002). War, peace, and fertility in angola. Demography, 39:215-31.

Aizer, A., Stroud, L., and Buka, S. (2016). Maternal stress and child outcomes: Evidence from siblings. Journal of Human Resources, 51(3):523-555.

Akseer, N., Wright, J., Tasic, H., Everett, K., Scudder, E., Amsalu, R., Boerma, T., Bendavid, E., Kamali, M., Barros, A. J., et al. (2020). Women, children and adolescents in conflict 
countries: an assessment of inequalities in intervention coverage and survival. BMJ Global Health, 5(1).

Almond, D., Currie, J., and Duque, V. (2018). Childhood circumstances and adult outcomes: Act ii. Journal of Economic Literature, 56(4):1360-1446.

Alvis-Zakzuk, N. J., Castañeda-Orjuela, C., Díaz-Jiménez, D., Castillo-Rodríguez, L., Cotes, K. P., Chaparro, P., Paternina-Caicedo, Á. J., Alvis-Guzmán, N. R., la Hoz, D., and Pío, F. (2018). Inequalities on mortality due to acute respiratory infection in children: A colombian analysis. Biomédica, 38(4):586-593.

Ananat, E. O., Gassman-Pines, A., and Gibson-Davis, C. (2013). Community-wide job loss and teenage fertility: evidence from north carolina. Demography, 50(6):2151-2171.

Arjona, A. (2016). Rebelocracy: Social Order in the Colombian Civil War. Cambridge Studies in Comparative Politics. Cambridge University Press.

Arjona, A. M. and Kalyvas, S. (2008). Una mirada micro al conflicto armado en colombia. resultados de una encuesta a desmovilizados de guerrillas y grupos paramilitares. Argumentación, negociación y acuerdos, pages 293-362.

Arkhangelsky, D., Athey, S., Hirshberg, D. A., Imbens, G. W., and Wager, S. (2021). Synthetic difference-in-differences. American Economic Review, 111(12):4088-4118.

Attanasio, O., Cortes, D., Gallego, J., Maldonado, D., Rodriguez, P., Charpak, N., Tessier, R., Ruiz, J. G., Hernandez, T., and Uriza, F. (2016). Early childhood interventions and parental investments: The long-run effect of the kangaroo mother care program $(\mathrm{kmc})$ on cognitive and socioemotional skills. CAF Skills for work and life, N 2016/02.

Ayllón, S. (2019). Job insecurity and fertility in europe. Review of Economics of the Household, 17(4):1321-1347.

Bardey, D. and Buitrago, G. (2017). Supplemental health insurance in the colombian managed care system: Adverse or advantageous selection? Journal of Health Economics, 56:317-329.

Becker, G. S. and Lewis, H. G. (1973). On the interaction between the quantity and quality of children. Journal of political Economy, 81(2, Part 2):S279-S288.

Bernal, C., Prem, M., Vargas, J. F., and Ortiz, M. (2022). Peaceful entry: Entrepreneurship dynamics during colombia's peace agreement.

Black, D. A., Kolesnikova, N., Sanders, S. G., and Taylor, L. J. (2013). Are children "normal"? The review of economics and statistics, 95(1):21-33.

Bleakley, H. and Lange, F. (2009). Chronic disease burden and the interaction of education, fertility, and growth. The review of economics and statistics, 91(1):52-65.

Brown, R. (2018). The mexican drug war and early-life health: The impact of violent crime on birth outcomes. Demography, 55(1):319-340. 
Brück, T. and Schindler, K. (2009). The impact of violent conflicts on households: What do we know and what should we know about war widows? Oxford Development Studies, 37(3):289-309.

Busetta, A., Mendola, D., and Vignoli, D. (2019). Persistent joblessness and fertility intentions. Demographic Research, 40:185-218.

Caldwell, J. C. (2006). Social upheaval and fertility decline. In Demographic Transition Theory, pages 273-299. Springer.

Camacho, A. (2008). Stress and birth weight: evidence from terrorist attacks. American Economic Review, 98(2):511-15.

Casey, S. E., McNab, S. E., Tanton, C., Odong, J., Testa, A. C., and Lee-Jones, L. (2013). Availability of long-acting and permanent family-planning methods leads to increase in use in conflict-affected northern uganda: evidence from cross-sectional baseline and endline cluster surveys. Global public health, 8(3):284-297.

Casey, S. E. and Tshipamba, M. (2017). Contraceptive availability leads to increase in use in conflict-affected democratic republic of the congo: evidence from cross-sectional cluster surveys, facility assessments and service statistics. Conflict and health, 11(1):110.

Castro Torres, A. F. and Urdinola, B. P. (2019). Armed conflict and fertility in colombia, 2000-2010. Population Research and Policy Review, 38(2):173-213.

CERAC (2016). Un año de desescalamiento: Conflicto casi detenido, pero que se resiste a desaparecer. Technical report, Centro de Recursos para el Análisis de Conflictos.

Chabé-Ferret, B. and Gobbi, P. (2021). Economic uncertainty and fertility cycles: Baby boom and busts in twentieth century america.

Chevalier, A. and Marie, O. (2017). Economic uncertainty, parental selection, and children's educational outcomes. Journal of Political Economy, 125(2):393-430.

Chi, P. C., Bulage, P., Urdal, H., and Sundby, J. (2015). Perceptions of the effects of armed conflict on maternal and reproductive health services and outcomes in burundi and northern uganda: a qualitative study. BMC International Health and Human Rights, 15(1):7.

Chukwuma, A. and Ekhator-Mobayode, U. E. (2019). Armed conflict and maternal health care utilization: evidence from the boko haram insurgency in nigeria. Social Science \& Medicine, 226:104-112.

Clark, A. E. and Lepinteur, A. (2020). A natural experiment on job insecurity and fertility in france. The Review of Economics and Statistics, pages 1-47.

Clifford, D., Falkingham, J., and Hinde, A. (2010). Through civil war, food crisis and drought: Trends in fertility and nuptiality in post-soviet tajikistan. European Journal of Population/Revue européenne de Démographie, 26(3):325-350. 
CNMH (2017). Una guerra sin edad. Centro Nacional de Memoria Histórica.

Coalition to Stop the Use of Child Soldiers (2008). Child Soldiers: Global Report 2008. Coalition to Stop the Use of Child Soldiers.

Colombia Implementation Working Group (2018). Colombia: A strategy to improve the registration and certification of vital events in rural and ethnic communities. crvs country perspectives. Technical report, Bloomberg Philanthropies Data for Health Initiative, Civil Registration and Vital Statistics Improvement, the University of Melbourne.

Conley, T. G. (1999). Gmm estimation with cross sectional dependence. Journal of Econometrics, 92(1):1-45.

Conley, T. G. (2016). Spatial Econometrics, pages 1-9. Palgrave Macmillan UK, London.

Crump, R. K., Hotz, V. J., Imbens, G. W., and Mitnik, O. A. (2009). Dealing with limited overlap in estimation of average treatment effects. Biometrika, 96(1):187-199.

Curlin, G. T., Chen, L. C., and Hussain, S. B. (1976). Demographic crisis: The impact of the bangladesh civil war (1971) on births and deaths in a rural area of bangladesh. Population Studies, 30(1):87-105.

De la Rica, S. and Iza, A. (2005). Career planning in spain: Do fixed-term contracts delay marriage and parenthood? Review of Economics of the Household, 3(1):49-73.

de Roux, N. and Martinez, L. R. (2020). Conflict reduces investment: Evidence from the demand for agricultural credit in colombia. Available at SSRN.

De Walque, D. (2006). The socio-demographic legacy of the khmer rouge period in cambodia. Population Studies, 60(2):223-231.

Departamento Administrativo Nacional de Estadística (DANE) (2005). Censo General 2005: Nivel Nacional. Departamento Administrativo Nacional de Estadística, Bogotá, Colombia.

Departamento Administrativo Nacional de Estadística (DANE) (2012). Metodología estadísticas vitales. Technical report, Departamento Administrativo Nacional de Estadística.

Departamento Administrativo Nacional de Estadística (DANE) (2020). Censo nacional de población y vivienda 2018.

Eskenazi, B., Marks, A. R., Catalano, R., Bruckner, T., and Toniolo, P. G. (2007). Low birthweight in new york city and upstate new york following the events of september 11th. Human Reproduction, 22(11):3013-3020.

Fearon, J. D. (2004). Why do some civil wars last so much longer than others? Journal of peace research, 41(3):275-301. 
Finlay, J. E. (2009). Fertility response to natural disasters: the case of three high mortality earthquakes. The World Bank.

Gopalan, S. S., Das, A., and Howard, N. (2017). Maternal and neonatal service usage and determinants in fragile and conflict-affected situations: a systematic review of asia and the middle-east. BMC Women's Health, 17(1):20.

Harbom, L., Melander, E., and Wallensteen, P. (2008). Dyadic dimensions of armed conflict, 1946-2007. Journal of peace research, 45(5):697-710.

Heath, R. and Mobarak, A. M. (2015). Manufacturing growth and the lives of bangladeshi women. Journal of development Economics, 115:1-15.

Heuveline, P. and Poch, B. (2007). The phoenix population: Demographic crisis and rebound in cambodia. Demography, 44(2):405-426.

Hondroyiannis, G. (2010). Fertility determinants and economic uncertainty: An assessment using european panel data. Journal of Family and Economic Issues, 31(1):33-50.

Idrobo, N., Mejía, D., and Tribin, A. M. (2014). Illegal gold mining and violence in colombia. Peace Economics, Peace Science and Public Policy, 20(1):83-111.

Jensen, R. (2012). Do labor market opportunities affect young women's work and family decisions? experimental evidence from india. The Quarterly Journal of Economics, 127(2):753-792.

Jones, D., Molitor, D., and Reif, J. (2019). What do workplace wellness programs do? evidence from the illinois workplace wellness study. The Quarterly Journal of Economics, 134(4):1747-1791.

Kalyvas, S. N. (2006). The logic of violence in civil war. Cambridge University Press.

Khashan, A. S., McNamee, R., Abel, K. M., Pedersen, M. G., Webb, R. T., Kenny, L. C., Mortensen, P. B., and Baker, P. N. (2008). Reduced infant birthweight consequent upon maternal exposure to severe life events. Psychosomatic Medicine, 70(6):688-694.

Kohler, H.-P., Billari, F. C., and Ortega, J. A. (2006). Low fertility in europe: Causes, implications and policy options. The baby bust: Who will do the work, pages 48-109.

Kraehnert, K., Brück, T., Di Maio, M., and Nisticò, R. (2018). The effects of conflict on fertility: Evidence from the genocide in rwanda. Demography.

Kreft, A.-K. (2020). Civil society perspectives on sexual violence in conflict: patriarchy and war strategy in colombia. International Affairs, 96(2):457-478.

Kreif, N., Mirelman, A., Suhrcke, M., Buitrago, G., and Moreno-Serra, R. (2022). The impact of civil conflict on child health: Evidence from colombia. Economics \& Human Biology, 44:101074. 
Leon, G. (2012). Civil conflict and human capital accumulation the long-term effects of political violence in perú. Journal of Human Resources, 47(4):991-1022.

Lindo, J. M. (2010). Are children really inferior goods? evidence from displacementdriven income shocks. Journal of Human Resources, 45(2):301-327.

Lovenheim, M. F. and Mumford, K. J. (2013). Do family wealth shocks affect fertility choices? evidence from the housing market. Review of Economics and Statistics, 95(2):464-475.

Mansour, H. and Rees, D. I. (2012). Armed conflict and birth weight: Evidence from the al-aqsa intifada. Journal of development Economics, 99(1):190-199.

Mejía, D. and Restrepo, P. (2015). Bushes and bullets: Illegal cocaine markets and violence in colombia. Documentos CEDE.

Ministerio de Salud y de la Proteccion Social (MinSalud) (2019). Cifras de aseguramiento en salud. Technical report, Ministerio de Salud y Protección Social.

Ministerio de Salud y de la Proteccion Social (MinSalud) and Profamilia (2017). Encuesta nacional de demografía y salud 2015. Bogotá, Colombia: Profamilia.

Modena, F., Rondinelli, C., and Sabatini, F. (2014). Economic insecurity and fertility intentions: The case of i taly. Review of Income and Wealth, 60:S233-S255.

Monitor, L. (2015). International campaign to ban landmines-cluster munition coalition (icbl-cmc).

Muralidharan, K. and Prakash, N. (2017). Cycling to school: Increasing secondary school enrollment for girls in india. American Economic Journal: Applied Economics, 9(3):321-50.

Nobles, J., Frankenberg, E., and Thomas, D. (2015). The effects of mortality on fertility: population dynamics after a natural disaster. Demography, 52(1):15-38.

OECD (2019). OECD family database.

Orach, C. G., Otim, G., Aporomon, J. F., Amone, R., Okello, S. A., Odongkara, B., and Komakech, H. (2015). Perceptions, attitude and use of family planning services in post conflict gulu district, northern uganda. Conflict and health, 9(1):1-11.

Perilla, S., Prem, M., Purroy, M. E., and Vargas, J. F. (2022). How peace saves lives: Evidence from colombia.

Pettersson, T., Davies, S., Deniz, A., Engström, G., Hawach, N., Högbladh, S., and Öberg, M. S. M. (2021). Organized violence 1989-2020, with a special emphasis on syria. Journal of Peace Research, 58(4):809-825.

Potter, J. E., Ordonez, M., and Measham, A. R. (1976). The rapid decline in colombian fertility. Population and Development Review, pages 509-528. 
Prem, M., Purroy, M. E., and Vargas, J. F. (2022a). Landmines: The local effects of demining.

Prem, M., Rivera, A., Romero, D., and Vargas, J. F. (2022b). Selective civilian targeting: The unintended consequences of partial peace. Quarterly Journal of Political Science, 17(3):317-354.

Prem, M., Saavedra, S., and Vargas, J. F. (2020). End-of-conflict deforestation: Evidence from colombia's peace agreement. World Development, 129:104852.

Prem, M., Vargas, J. F., and Mejía, D. (2021a). The rise and persistence of illegal crops: Evidence from a naive policy announcement. The Review of Economics and Statistics, pages $1-42$.

Prem, M., Vargas, J. F., and Namen, O. (2021b). The human capital peace dividend. Journal of Human Resources, pages 0320-10805R2.

Price, J. I. and Bohara, A. K. (2013). Maternal health care amid political unrest: the effect of armed conflict on antenatal care utilization in nepal. Health Policy and Planning, 28(3):309-319.

Restrepo, J. A., Spagat, M., and Vargas, J. F. (2003). The dynamics of the colombian civil conflict: A new data set. CEPR Discussion Paper.

Rexer, J. M. (2022). The Brides of Boko Haram: Economic Shocks, Marriage Practices, and Insurgency in Nigeria. The Economic Journal.

Rutayisire, P. C. (2014). Changes in fertility decline in rwanda: A decomposition analysis. International Journal of Population Research, Volume 2014:10.

Schindler, K. and Bruck, T. (2011). The effects of conflict on fertility in Rwanda. Policy Research Working Paper Series 5715, The World Bank.

Schneider, D. (2015). The great recession, fertility, and uncertainty: Evidence from the united states. Journal of Marriage and Family, 77(5):1144-1156.

Schultz, T. P. (1985). Changing world prices, women's wages, and the fertility transition: Sweden, 1860-1910. Journal of Political Economy, 93(6):1126-1154.

Schultz, T. P. (1997). Demand for children in low income countries. Handbook of population and family economics, 1:349-430.

Shemyakina, O. (2009). The marriage market and tajik armed conflict. Brighton, UK: Households in Conflict Network (HiCN). Working Paper, 66.

Sommer, K. (2016). Fertility choice in a life cycle model with idiosyncratic uninsurable earnings risk. Journal of Monetary Economics, 83:27-38.

Svallfors, S. (2021a). Contraceptive choice as risk reduction? the relevance of local violence for women's uptake of sterilization in colombia. Population studies, pages 1-20. 
Svallfors, S. (2021b). Hidden casualties: The links between armed conflict and intimate partner violence in colombia. Politics \& Gender, pages 1-33.

Svallfors, S. and Billingsley, S. (2019). Conflict and contraception in colombia. Studies in family planning, 50(2):87-112.

Toro Roa, J. P., Iunes, R. F., and Mills, S. (2019). Achieving health outcomes in colombia: Civil registration and vital statistics system, unique personal identification number, and unified beneficiary registry system for births and deaths.

Tunçalp, Ö., Fall, I. S., Phillips, S. J., Williams, I., Sacko, M., Touré, O. B., Thomas, L. J., and Say, L. (2015). Conflict, displacement and sexual and reproductive health services in mali: analysis of 2013 health resources availability mapping system (herams) survey. Conflict and Health, 9(1):28.

UN (2019). World population prospects 2019.

Urdal, H. and Che, C. P. (2013). War and gender inequalities in health: the impact of armed conflict on fertility and maternal mortality. International Interactions, 39(4):489510.

Vargas, I., Vázquez, M. L., Mogollón-Pérez, A. S., and Unger, J.-P. (2010). Barriers of access to care in a managed competition model: lessons from colombia. BMC Health Services Research, 10(1):297.

Verwimp, P. and Bavel, J. (2005). Child survival and fertility of refugees in rwanda. European Journal of Population / Revue européenne de Démographie, 21:271-290.

Walker, S. P., Chang, S. M., Vera-Hernández, M., and Grantham-McGregor, S. (2011). Early childhood stimulation benefits adult competence and reduces violent behavior. Pediatrics, 127(5):849-857.

Westfall, P. H. and Young, S. S. (1993). Resampling-based multiple testing: Examples and methods for p-value adjustment, volume 279. John Wiley \& Sons.

Williams, N. E., Ghimire, D. J., Axinn, W. G., Jennings, E. A., and Pradhan, M. S. (2012). A micro-level event-centered approach to investigating armed conflict and population responses. Demography, 49(4):1521-1546.

Wirtz, A. L., Pham, K., Glass, N., Loochkartt, S., Kidane, T., Cuspoca, D., Rubenstein, L. S., Singh, S., and Vu, A. (2014). Gender-based violence in conflict and displacement: qualitative findings from displaced women in colombia. Conflict and health, 8(1):1-14.

Woldemicael, G. (2008). Recent fertility decline in eritrea: Is it a conflict-led transition? Demographic Research, 18:27-58.

World Health Organization and others (WHO) (2018). Who recommendation on antenatal care contact schedules. 
Figure 1: Change in conflict after ceasefire

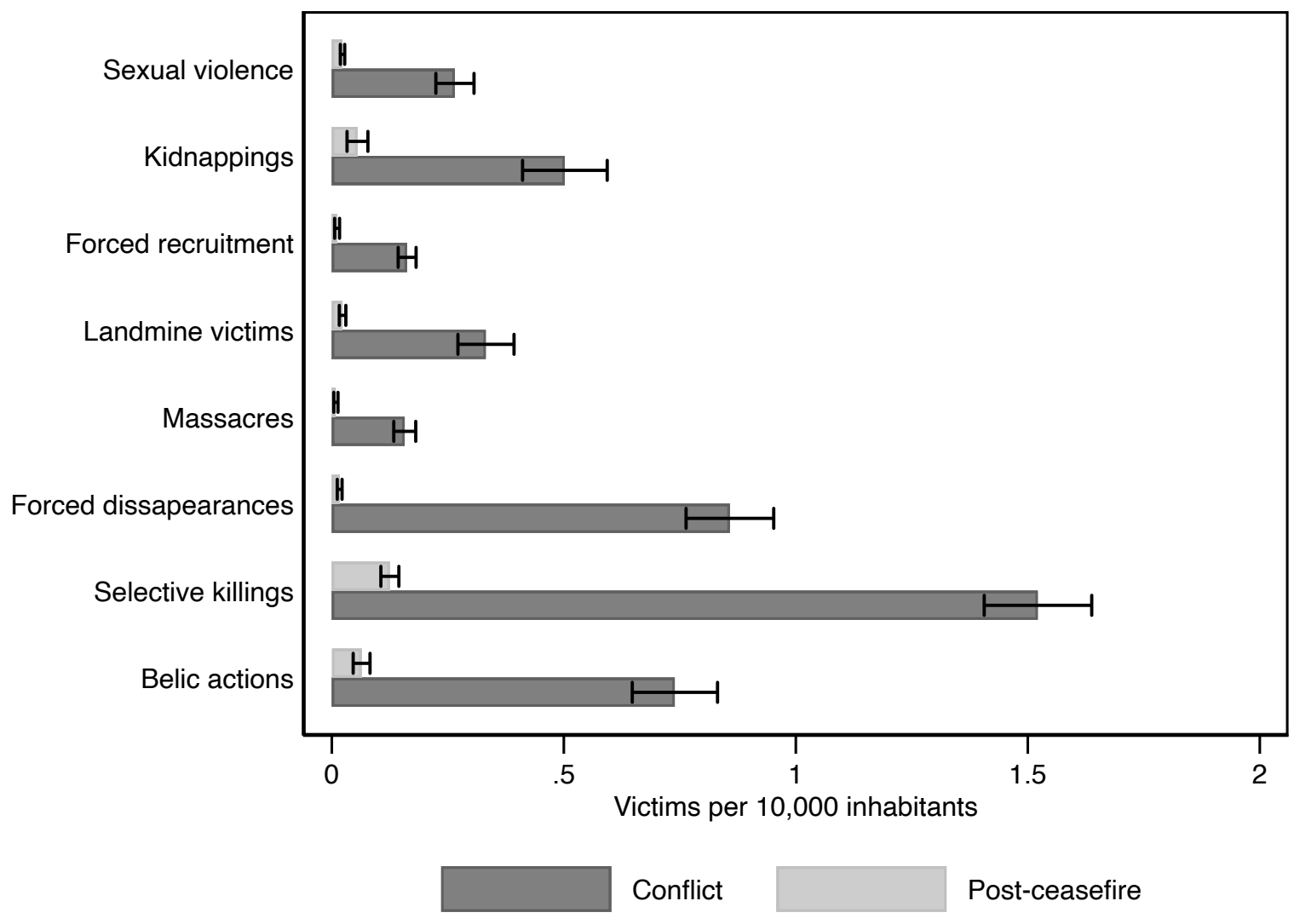

Notes: This figure presents the change in conflict related events after the ceasefire. We present average across municipalities and $95 \%$ confidence intervals. 
Figure 2: Dynamic difference-in-differences for total fertility rate

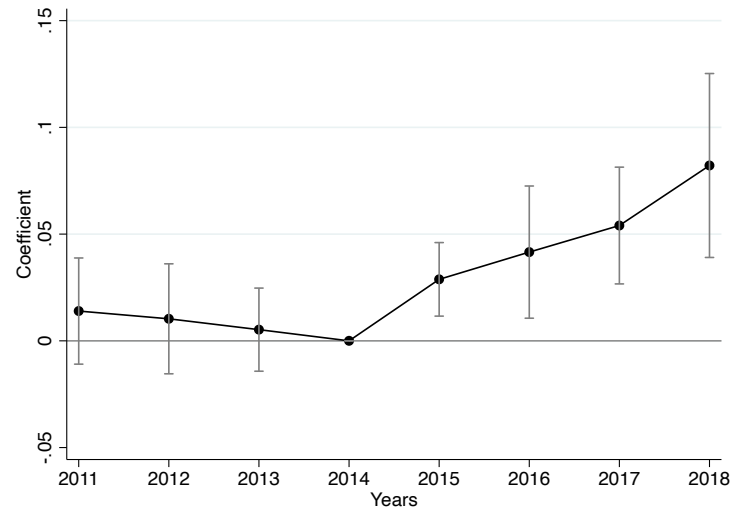

(a) Baseline

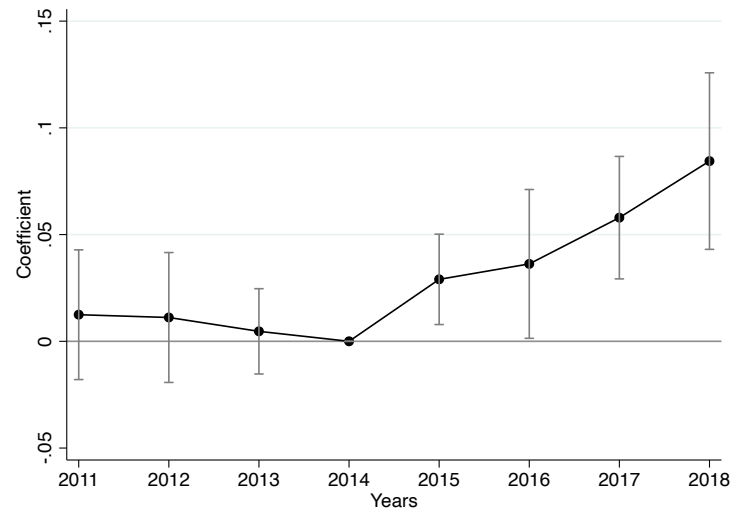

(c) Adds dept-year FE and baseline controls

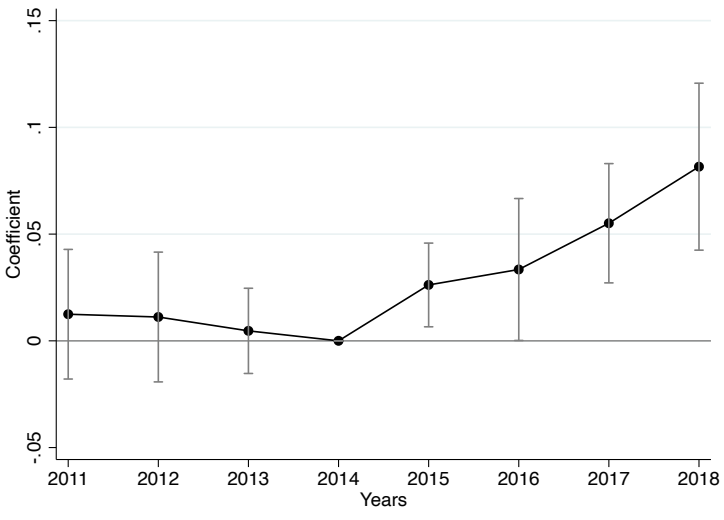

(b) Adds dept-year FE

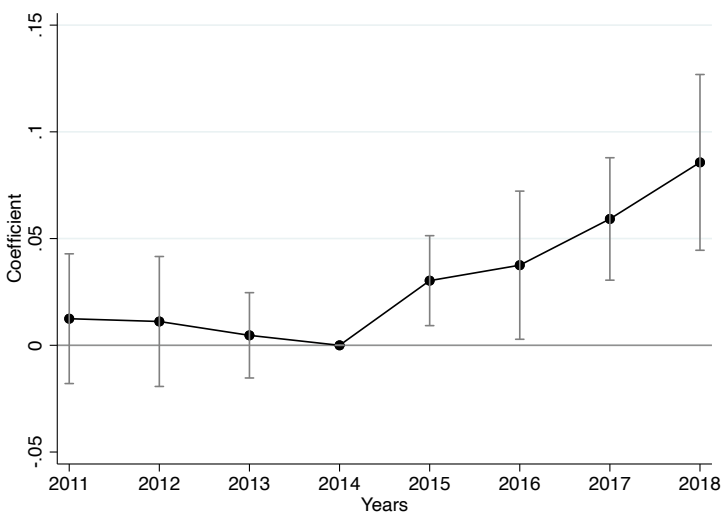

(d) Adds dept-year FE, and baseline and illegal activities controls

Notes: These figures present the coefficients from our specification presented in equation (3). Panel (a) includes municipality and year fixed effects, Panel (b) includes municipality and department/year fixed effects, Panel (c) includes municipality and department/year fixed effects, and baseline controls, and Panel (d) includes municipality and department/year fixed effects, and baseline controls and controls associated with violent and illegal activities. We present the point estimates of the regressions and the $95 \%$ confidence interval. 
Table 1: Total fertility rate and ceasefire

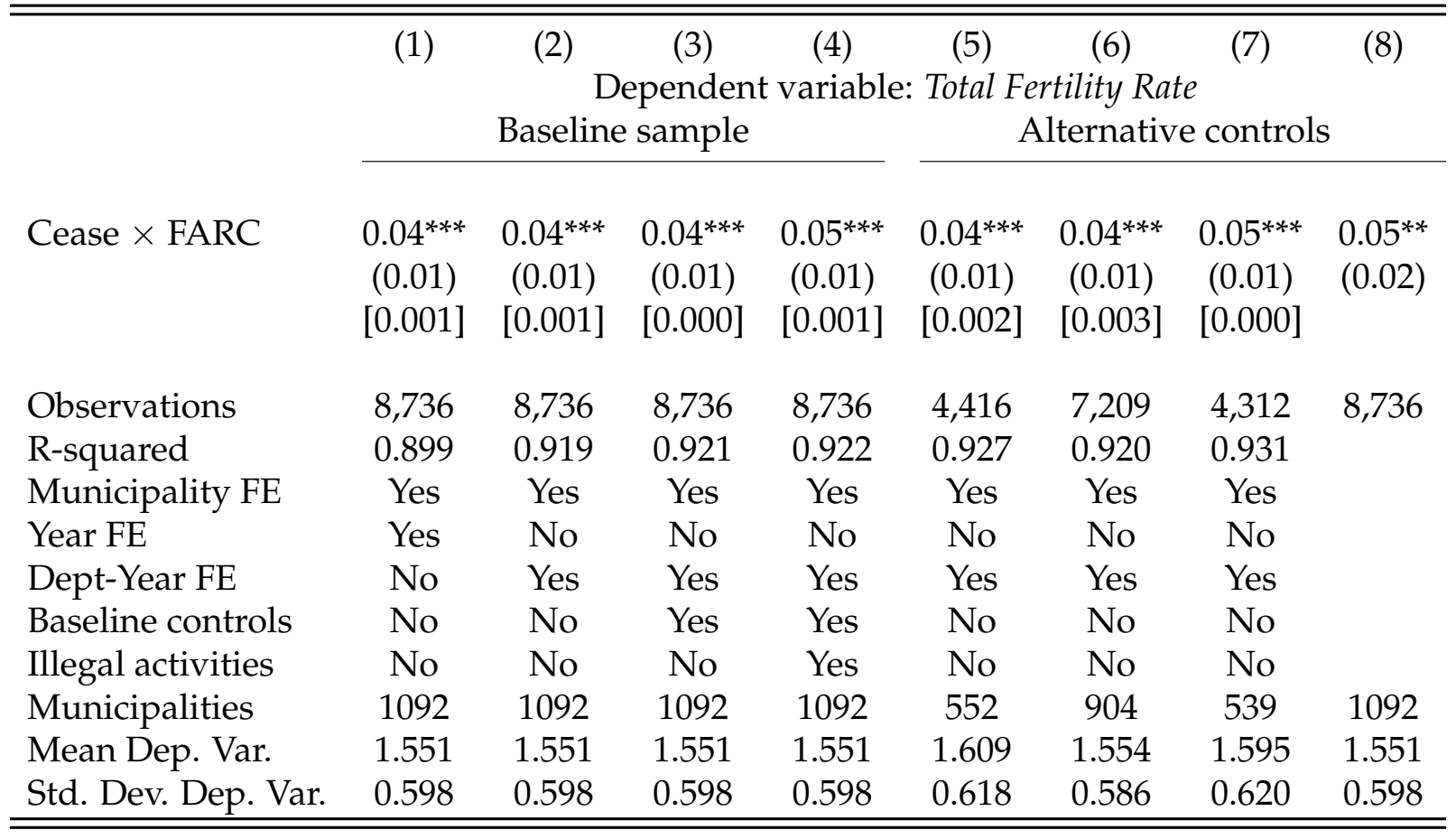

Notes: This table presents the results from the main specification in equation (2). All regressions are weighted by the number of live births between 2011 to 2014 for each age group. Cease is a dummy that takes the value for the period after 2014. FARC is a continuous measure of the total number of FARC attacks over 10,000 inhabitants from 2011 to 2014, and is standardized by the mean and standard deviation to ease interpretation. Total Fertility Rate is the number of live births from a hypothetical woman in her reproductive life (15-45 years of age). It is computed as the sum of age-specific fertility rates weighted by the number of years in each age group (i.w, multiplied by 5), divided by 1,000. Column 3 adds predetermined municipal controls interacted with the ceasefire dummy. These controls include infant mortality rate, number of victims related to anti-personnel mines, share of rural population, distance to the department capital, poverty index, and logarithm of the population in 2010. In column 4, we add as additional controls coca and gold suitability and a dummy for any attacks of other armed groups from 2011 to 2014. In column 5, we restrict the sample to only municipalities that experienced at least one attack from an illegal armed group between 2011 and 2014. In column 6, we exclude from the control municipalities those that were neighbours of FARC affected municipalities. In column 7 , we estimate a propensity score using all the previously mentioned covariates and then truncate the empirical distribution of the propensity score using the optimal cut by Crump et al. (2009). In column 8, we estimate a synthetic difference-in-differences model following Arkhangelsky et al. (2021). Clustered robust standard errors at the municipality level are presented in parenthesis. In square brackets, we present the p-values for standard errors control for spatial and first-order time correlation (see Conley, 1999, Conley, 2016). We allow spatial correlation to extend to up to $416 \mathrm{~km}$ from each municipality's centroid, which is the average distance from one municipality to all the rest. * $p$ is significant at the $10 \%$ level, ${ }^{* *} p$ is significant at the $5 \%$ level, ${ }^{* * *} p$ is significant at the $1 \%$ level. 


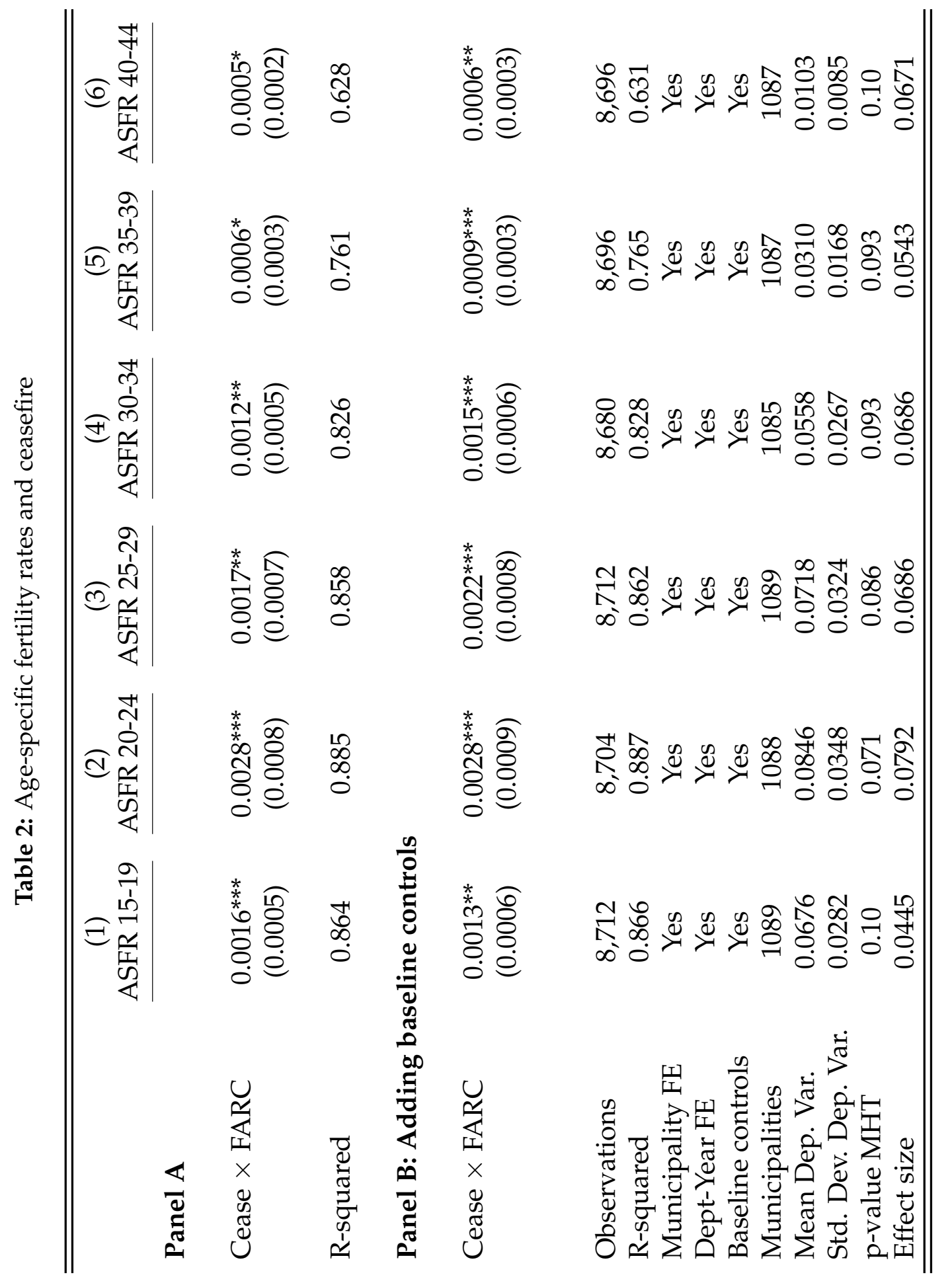

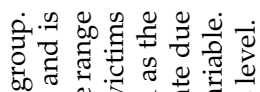

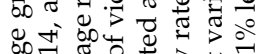

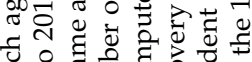

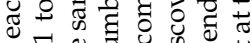

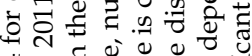

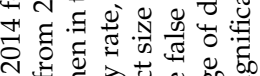

人.

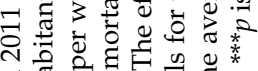

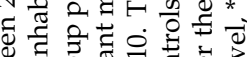

उ 은

\& 8 i

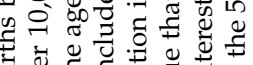

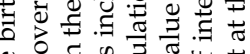

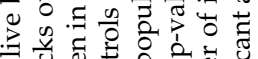

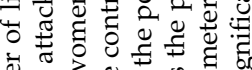

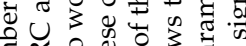

준월 द्या

要

है을

प्रे

क.

उ.

ป

告㟔:

क

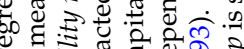

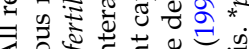

论

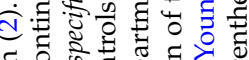

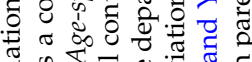

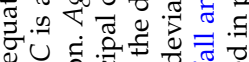

ङ

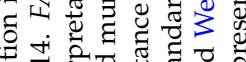

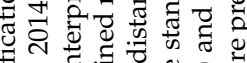

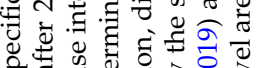

क्र

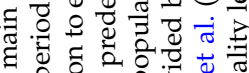

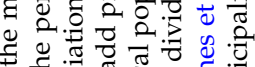

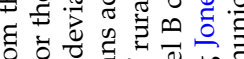

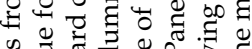

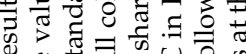

Q

F

品

㐘

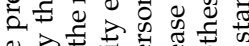

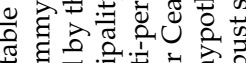

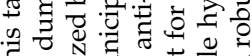

的乎

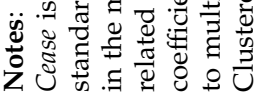


Table 3: Heterogeneous effects by municipality characteristics

\begin{tabular}{|c|c|c|c|c|c|c|}
\hline & & Dependen & ariable: Total ft & ility rate & & \\
\hline & (1) & (2) & (3) & (4) & (5) & (6) \\
\hline Z: & $\begin{array}{l}\text { Mines } \\
\text { victims }\end{array}$ & $\begin{array}{c}\text { Forced } \\
\text { displacement }\end{array}$ & $\begin{array}{l}\text { Child } \\
\text { recruitment }\end{array}$ & $\begin{array}{l}\text { Vote share } \\
\text { pro-peace }\end{array}$ & $\begin{array}{c}\text { Infant } \\
\text { mortality }\end{array}$ & ETCR \\
\hline Cease $\times$ FARC $\times Z$ & $0.01^{* *}$ & $0.02^{* * *}$ & $0.01^{*}$ & $0.01^{*}$ & 0.01 & $0.11^{* *}$ \\
\hline & $(0.01)$ & $(0.01)$ & $(0.00)$ & $(0.01)$ & $(0.01)$ & $(0.05)$ \\
\hline Cease $\times$ FARC & $0.03^{* *}$ & $0.03^{*}$ & $0.04^{* * *}$ & $0.03^{* *}$ & $0.04^{* * *}$ & $0.03^{* * *}$ \\
\hline & $(0.01)$ & $(0.01)$ & $(0.01)$ & $(0.01)$ & $(0.01)$ & $(0.01)$ \\
\hline Cease $\times Z$ & $-0.02^{* *}$ & $-0.04^{* * *}$ & -0.01 & -0.01 & $0.04^{* *}$ & -0.06 \\
\hline & $(0.01)$ & $(0.01)$ & $(0.01)$ & $(0.02)$ & $(0.02)$ & $(0.06)$ \\
\hline Observations & 8,701 & 8,701 & 8,701 & 8,695 & 8,701 & 8,701 \\
\hline R-squared & 0.920 & 0.920 & 0.919 & 0.919 & 0.919 & 0.920 \\
\hline Municipality FE & Yes & Yes & Yes & Yes & Yes & Yes \\
\hline Dept-Year FE & Yes & Yes & Yes & Yes & Yes & Yes \\
\hline Controls & No & No & No & No & No & No \\
\hline Municipalities & 1092 & 1092 & 1092 & 1091 & 1092 & 1092 \\
\hline Mean Dep. Var. & 1.606 & 1.606 & 1.606 & 1.607 & 1.606 & 1.606 \\
\hline Std. Dev. Dep. Var. & 0.596 & 0.596 & 0.596 & 0.595 & 0.596 & 0.596 \\
\hline
\end{tabular}

Notes: This table presents the results from our specification presented in equation (4). Cease is a dummy that takes the value for the period after 2014. FARC is a continuous measure of the total number of FARC attacks over 10,000 inhabitants from 2011 to 2014 , and is standardized by the mean and standard deviation to ease interpretation. Mines victims is a standardized measure of the number of victims related to antipersonnel landmines between 2011 and 2014 over population. Forced displacement is the number of population expelled in a municipality due to forced displacement between 2011 and 2014 over population. Child recruitment is a standardized measure of the number of children recruited by illegal armed groups in 2014 over population. Vote share pro-peace is the standardized vote share in favor of the peace agreement in the 2016 Plebiscite. Infant mortality is the number of deaths of children under 1 year old between 2011 and 2014 per 1,000 live births. ETCR is a dummy that takes the value for municipalities with Territorial Training and Reincorporation Spaces. Robust standard errors are clustered at the municipality level and presented in parenthesis. Clustered robust standard error at the municipality level are presented in parenthesis. ${ }^{*} p$ is significant at the $10 \%$ level, ${ }^{* *} p$ is significant at the $5 \%$ level, *** $p$ is significant at the $1 \%$ level. 
Table 4: Infrastructure and operation of the health sector

\begin{tabular}{|c|c|c|c|c|c|c|}
\hline & $\begin{array}{c}(1) \\
\text { Antenatal } \\
\text { care }\end{array}$ & $\begin{array}{c}\text { (2) } \\
\text { Births } \\
\text { attended by } \\
\text { health prof }\end{array}$ & Ambulances & $\begin{array}{c}(4) \\
\text { Therapeutic } \\
\text { support }\end{array}$ & $\begin{array}{l}\text { (5) } \\
\text { Hospital } \\
\text { beds }\end{array}$ & $\begin{array}{c}(6) \\
\text { Medical } \\
\text { wards }\end{array}$ \\
\hline \multicolumn{7}{|l|}{ Panel A } \\
\hline Cease $\times$ FARC & $\begin{array}{l}-0.01 \\
(0.02)\end{array}$ & $\begin{array}{l}-0.19 \\
(0.18)\end{array}$ & $\begin{array}{c}0.01 \\
(0.10)\end{array}$ & $\begin{array}{c}-0.94^{* * *} \\
(0.34)\end{array}$ & $\begin{array}{l}-1.09 \\
(1.25)\end{array}$ & $\begin{array}{c}-0.89^{* *} \\
(0.36)\end{array}$ \\
\hline R-squared & 0.921 & 0.852 & 0.938 & 0.675 & 0.964 & 0.831 \\
\hline \multicolumn{7}{|c|}{ Panel B: Adding baseline controls } \\
\hline Cease $\times$ FARC & $\begin{array}{l}0.03^{* *} \\
(0.01)\end{array}$ & $\begin{array}{l}-0.15 \\
(0.19)\end{array}$ & $\begin{array}{c}0.13 \\
(0.10)\end{array}$ & $\begin{array}{c}0.22 \\
(0.30)\end{array}$ & $\begin{array}{c}0.21 \\
(1.24)\end{array}$ & $\begin{array}{l}-0.03 \\
(0.21)\end{array}$ \\
\hline Observations & 8,736 & 8,736 & 7,586 & 7,586 & 7,586 & 7,586 \\
\hline Municipalities & 1092 & 1092 & 1092 & 1092 & 1092 & 1092 \\
\hline R-squared & 0.923 & 0.853 & 0.942 & 0.738 & 0.968 & 0.883 \\
\hline Municipality FE & Yes & Yes & Yes & Yes & Yes & Yes \\
\hline Dept-Year FE & Yes & Yes & Yes & Yes & Yes & Yes \\
\hline Mean Dep. Var. & 5.667 & 96.88 & 2.273 & 0.130 & 21.03 & 1.675 \\
\hline Std. Dev. Dep. Var. & 1.138 & 9.585 & 3.866 & 1.925 & 50.92 & 2.929 \\
\hline p-value MHT & 0.249 & 0.915 & 0.673 & 0.915 & 0.982 & 0.982 \\
\hline
\end{tabular}

Notes: This table presents the results from the main specification in equation (2). All regressions are weighted by the number of live births between 2011 to 2014. Cease is a dummy that takes the value for the period after 2014. FARC is a continuous measure of the total number of FARC attacks over 10,000 inhabitants from 2011 to 2014, and is standardized by the mean and standard deviation to ease interpretation.Ante-natal care visits refers to the average of ante-natal care visits in the municipality per 100 live births in the municipality each year. Births attended by health professional is the proportion of live births that were attended by a doctors, nurses, health promoters and nursing assistants. Ambulances is the number of ambulances for every 1,000 inhabitants. Therapeutic support is the number of therapeutic chairs for every 1,000 inhabitants. Hospital beds is the number of hospital beds for every 1,000 inhabitants. Medical wards is the number of medical wards (delivery room, procedure room, and operating room) for every 1,000 inhabitants. All columns in panel B add predetermined municipal controls interacted with the ceasefire dummy. These controls include infant mortality rate, number of victims related to anti-personnel mines, share of rural population, distance to the department capital, poverty index, and logarithm of the population in 2010. p-value MHT shows the p-value that controls for the false discovery rate due to multiple hypothesis testing following Jones et al. (2019) and Westfall and Young (1993). Clustered robust standard errors at the municipality level are presented in parenthesis. ${ }^{*} p$ is significant at the $10 \%$ level, ${ }^{* *} p$ is significant at the $5 \%$ level, ${ }^{* * *} p$ is significant at the $1 \%$ level. 
Table 5: Neonatal and infant mortality

\begin{tabular}{|c|c|c|c|c|c|c|}
\hline & $\begin{array}{c}(1) \\
\text { Fetal }\end{array}$ & $\begin{array}{c}(2) \\
\text { Neonatal }\end{array}$ & $\begin{array}{c}(3) \\
\text { Infant }\end{array}$ & $\begin{array}{l}\text { (4) } \\
\text { Unde }\end{array}$ & Under-5 mortality & $\begin{array}{l}\text { (6) } \\
\text { lity }\end{array}$ \\
\hline & mortality & mortality & mortality & Overall & ADD & ARI \\
\hline \multicolumn{7}{|l|}{ Panel A } \\
\hline Cease $\times$ FARC & $\begin{array}{l}-0.24 \\
(1.29)\end{array}$ & $\begin{array}{l}-0.19 \\
(0.13)\end{array}$ & $\begin{array}{l}-0.58^{*} \\
(0.31)\end{array}$ & $\begin{array}{l}-0.28 \\
(0.20)\end{array}$ & $\begin{array}{l}-0.69 \\
(0.52)\end{array}$ & $\begin{array}{c}0.59 \\
(1.19)\end{array}$ \\
\hline R-squared & 0.740 & 0.256 & 0.415 & 0.454 & 0.431 & 0.362 \\
\hline \multicolumn{7}{|c|}{ Panel B: Adding baseline controls } \\
\hline Cease $\times$ FARC & $\begin{array}{c}1.17 \\
(1.24)\end{array}$ & $\begin{array}{l}-0.04 \\
(0.13)\end{array}$ & $\begin{array}{c}0.02 \\
(0.27)\end{array}$ & $\begin{array}{c}0.02 \\
(0.19)\end{array}$ & $\begin{array}{l}-0.85 \\
(0.52)\end{array}$ & $\begin{array}{c}0.86 \\
(1.26)\end{array}$ \\
\hline Observations & 8,505 & 8,736 & 8,736 & 8,736 & 8,736 & 8,736 \\
\hline R-squared & 0.742 & 0.281 & 0.448 & 0.474 & 0.432 & 0.363 \\
\hline Municipality FE & Yes & Yes & Yes & Yes & Yes & Yes \\
\hline Dept-Year FE & Yes & Yes & Yes & Yes & Yes & Yes \\
\hline Controls & Yes & Yes & Yes & Yes & Yes & Yes \\
\hline Municipalities & 1064 & 1092 & 1092 & 1092 & 1092 & 1092 \\
\hline Mean Dep. Var. & 42.97 & 7.531 & 25.22 & 16.09 & 3.950 & 12.86 \\
\hline Std. Dev. Dep. Var. & 43.93 & 10.46 & 29.49 & 17.68 & 26.85 & 40.74 \\
\hline p-value MHT & 0.84 & 0.972 & 0.99 & 0.99 & 0.534 & 0.891 \\
\hline
\end{tabular}

Notes: This table presents the results from the main specification in equation (2). Fetal mortality rate is the number of fetal deaths, regardless of the gestational age of the fetus, per 1,000 known pregnancies. Neonatal mortality rate refers to the number of newborns who died before 28 days of life per 1,000 live births per year. Infant mortality rate is the number of deaths under 1 year old per 1,000 live births per year. Under-five mortality rate is the number of deaths under 5 years old per 1,000 live births per year. ADD and ARI means Acute Diarrhoeal Disease and Acute Respiratory Infections, respectively. All regressions are weighted by the number of live births between 2011 to 2014 . Cease is a dummy that takes the value for the period after 2014. FARC is a continuous measure of the total number of FARC attacks over 10,000 inhabitants from 2011 to 2014, and is standardized by the mean and standard deviation to ease interpretation. All columns in panel B add predetermined municipal controls interacted with the ceasefire dummy. These controls include number of victims related to anti-personnel mines, share of rural population, distance to the department capital, poverty index and logarithm of the population in 2010. p-value MHT shows the p-value that controls for the false discovery rate due to multiple hypothesis testing following Jones et al. (2019) and Westfall and Young (1993). Clustered robust standard errors at the municipality level are presented in parenthesis. ${ }^{*} p$ is significant at the $10 \%$ level, ${ }^{* *} p$ is significant at the $5 \%$ level, ${ }^{* * *} p$ is significant at the $1 \%$ level. 
Table 6: Newborn health

\begin{tabular}{|c|c|c|c|c|c|}
\hline & $(1)$ & $\begin{array}{l}(2) \\
\mathrm{AP}\end{array}$ & $\begin{array}{l}(3) \\
A R\end{array}$ & \multirow[b]{2}{*}{$\begin{array}{c}\text { Preterm } \\
\text { birth }\end{array}$} & \multirow[b]{2}{*}{$\begin{array}{c}\text { C-Section } \\
\text { delivery }\end{array}$} \\
\hline & LBW & $1 \mathrm{~min}$ & $5 \mathrm{~min}$ & & \\
\hline \multicolumn{6}{|l|}{ Panel A } \\
\hline Cease $\times$ FARC & $\begin{array}{l}-0.07 \\
(0.06)\end{array}$ & $\begin{array}{c}0.00 \\
(0.00)\end{array}$ & $\begin{array}{l}-0.00 \\
(0.00)\end{array}$ & $\begin{array}{l}-0.22^{*} \\
(0.12)\end{array}$ & $\begin{array}{l}-0.10 \\
(0.21)\end{array}$ \\
\hline R-squared & 0.563 & 0.813 & 0.756 & 0.635 & 0.922 \\
\hline \multicolumn{6}{|c|}{ Panel B: Adding baseline controls } \\
\hline Cease $\times$ FARC & $\begin{array}{l}-0.06 \\
(0.07)\end{array}$ & $\begin{array}{c}0.00 \\
(0.00)\end{array}$ & $\begin{array}{l}-0.00 \\
(0.00)\end{array}$ & $\begin{array}{l}-0.23^{*} \\
(0.12)\end{array}$ & $\begin{array}{c}0.13 \\
(0.18)\end{array}$ \\
\hline Observations & 8,736 & 8,736 & 8,736 & 8,736 & 8,736 \\
\hline R-squared & 0.563 & 0.813 & 0.757 & 0.637 & 0.925 \\
\hline Municipality FE & Yes & Yes & Yes & Yes & Yes \\
\hline Dept-Year FE & Yes & Yes & Yes & Yes & Yes \\
\hline Controls & Yes & Yes & Yes & Yes & Yes \\
\hline Municipalities & 1092 & 1092 & 1092 & 1092 & 1092 \\
\hline Mean Dep. Var. & 7.783 & 8.109 & 9.534 & 17.03 & 35.12 \\
\hline Std. Dev. Dep. Var. & 4.257 & 0.613 & 0.684 & 6.011 & 14.68 \\
\hline p-value MHT & 0.865 & 0.865 & 0.865 & 0.383 & 0.865 \\
\hline
\end{tabular}

Notes: This table presents the results from the main specification in equation (2). All regressions are weighted by the number of live births between 2011 to 2014. Cease is a dummy that takes the value for the period after 2014. FARC is a continuous measure of the total number of FARC attacks over 10,000 inhabitants from 2011 to 2014, and is standardised by the mean and standard deviation to ease interpretation. $L B W$ is the percentage of newborns who weighted less than 2500 grams. APGAR1 is the mean APGAR test after 1 minute, and APGAR5 is after 5 minutes. Preterm birth corresponds to the percentage of babies who were born alive before 37 gestational weeks. C-Section delivery is the number of babies delivered by caesarean per 100 live births. All columns in panel B add predetermined municipal controls interacted with the ceasefire dummy. These controls include infant mortality rate, number of victims related to anti-personnel mines, share of rural population, distance to the department capital, poverty index, and logarithm of the population in 2010. $p$-value MHT shows the p-value that controls for the false discovery rate due to multiple hypothesis testing following Jones et al. (2019) and Westfall and Young (1993). Clustered robust standard error at the municipality level are presented in parenthesis. ${ }^{*} p$ is significant at the $10 \%$ level, ${ }^{* *} p$ is significant at the $5 \%$ level, ${ }^{* * *} p$ is significant at the $1 \%$ level. 


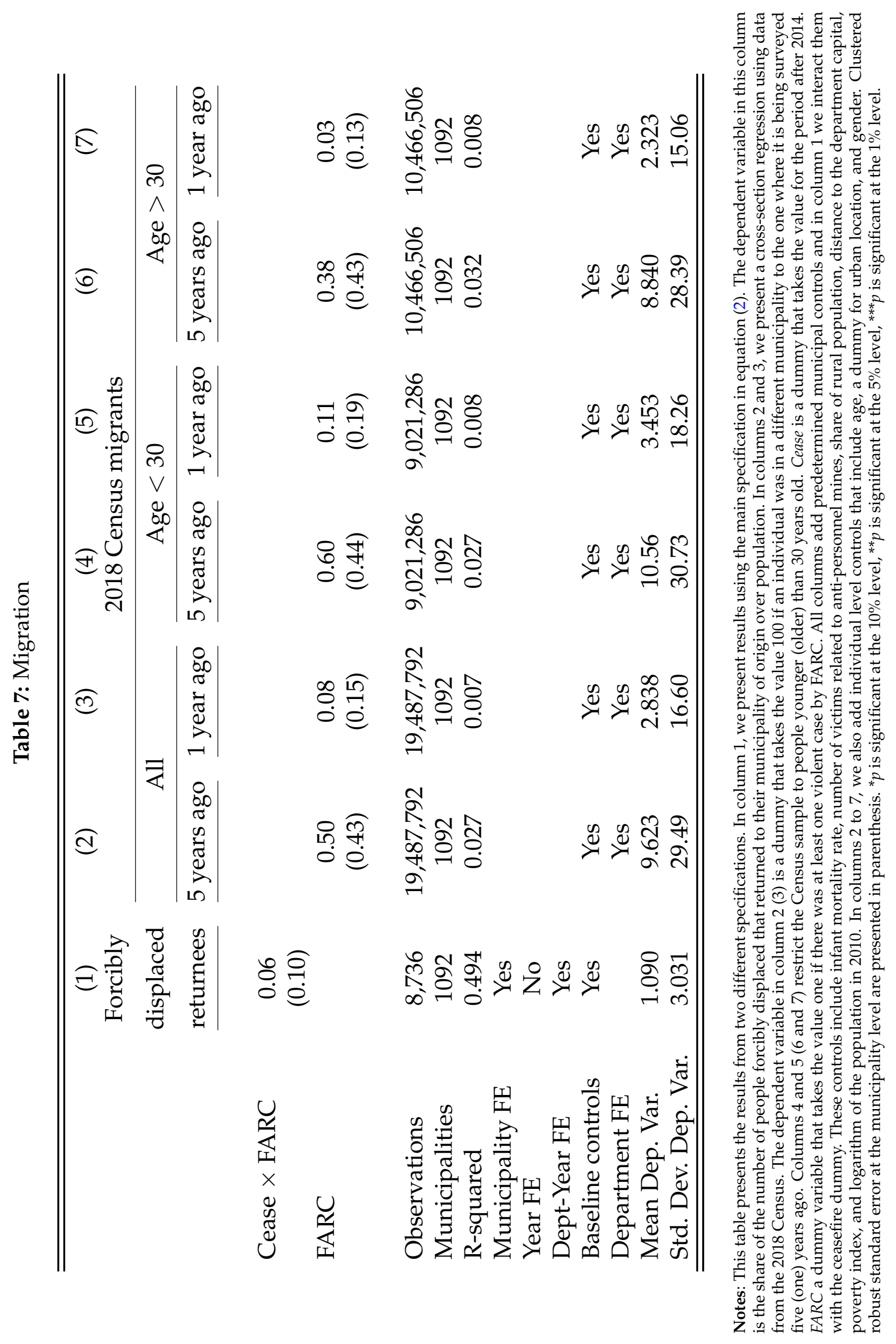




\section{Online Appendix (Not for publication)}

\section{A Peace Baby Boom? Evidence from Colombia's Peace Agreement}

María Elvira Guerra-Cújar, Mounu Prem, Paul Rodriguez-Lesmes and Juan F. Vargas

\section{Data appendix: Description of variables and sources}

Dependent variables. We used four different databases to create the dependent variables: The source for creating the fertility and health variables is the integrated system of the Ministry of Health and Social Protection (SISPRO) and Colombia's National Department of Statistics (DANE). The former system receives and processes data, in a single warehouse, from the institutions of the Social Protection sector: health, pensions, professional risks, and social promotion. The latter is in charge of planning, implementing, and evaluating processes for the production and communication of statistical information at the national level, which support the understanding and solution of the country's social, economic, and environmental problems and serve as a basis for the public and private decision-making.

The health sector's infrastructure data is collected by the Special Register of Health Service Providers (REPS from the Spanish acronym), the official database where all health service providers in the country and their services are registered. Finally, to obtain information on marital status, we used the censuses conducted between 2005 and 2018.

The rates are computed per year at the municipal level based on the Public Health Surveillance Protocols. This guide standardizes the criteria, procedures, and activities to systematize the surveillance of events of interest in public health by the National Institute of Health (Colombia). It contains the formulas for calculating the indicators based on the criteria established by the World Health Organization and the 10th revision of the International Statistical Classification of Diseases and Related Health Problems (ICD10).

The violence dataset was originally compiled by Restrepo et al. (2003) and was updated through 2014 by Universidad del Rosario. This dataset codes violent events recorded in the Night and Fog reports from the NGO Center for Research and Popular Education (CINEP), which provides a detailed description of the violent event, its date of occurrence, the municipality in which it took place, the identity of the perpetrator, and the count of the victims involved in the incident.

Control variables and municipality characteristics. The primary source of these databases is the annual panel of Colombian municipalities, maintained and hosted by the Center For Economic Development Studies (CEDE from the Spanish acronym, Acevedo et al., 2014), a think-tank at Universidad de los Andes. Also, we use the Decontaminate Colombia database hosted by the Office of the High Commissioner for Peace, the Victim's Registry database, the Centro Nacional de Memoria Histórica, and the Agency for Reincorporation and Standardization database. 


\section{Additional Figures and Tables}

Figure A.1: Synthetic difference-in-differences for the total fertility rate

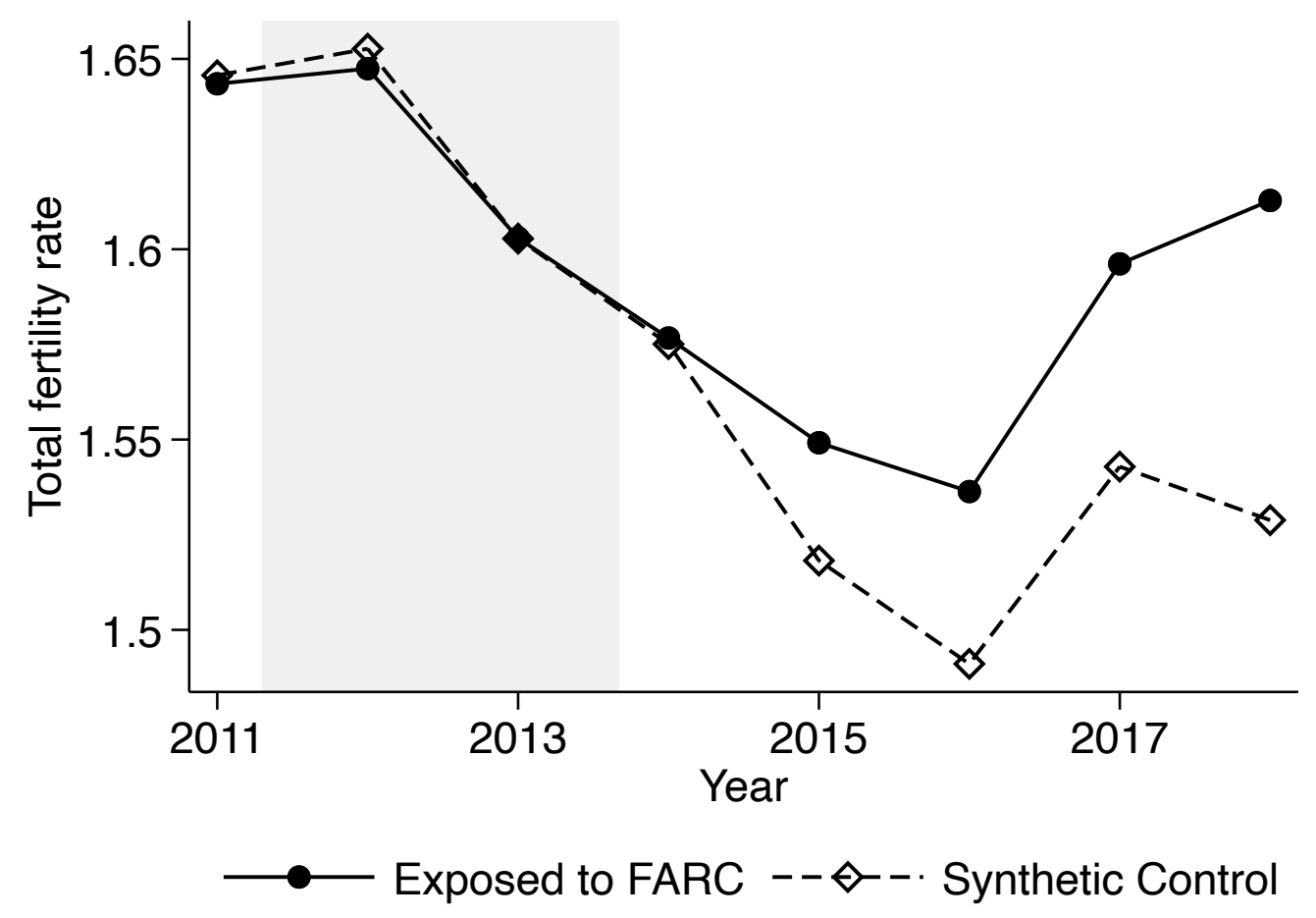

Notes: In this figure, we estimate a synthetic difference-in-differences model following Arkhangelsky et al. (2021). 
Figure A.2: Dynamic difference-in-differences for birth rate

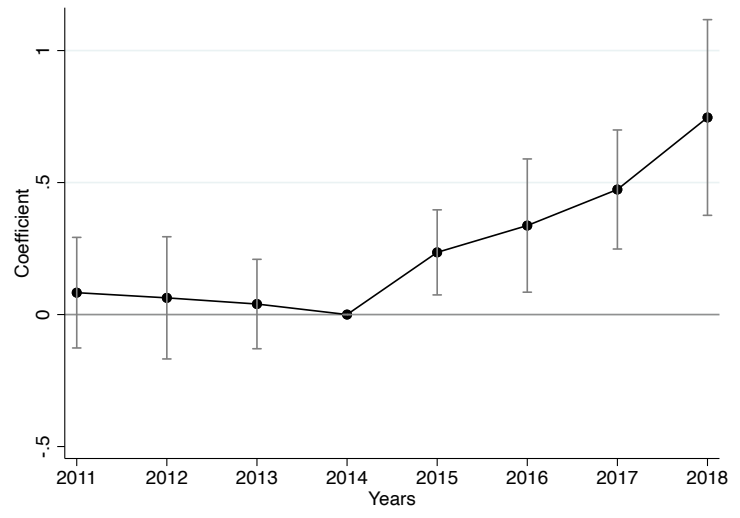

(a.1) Baseline

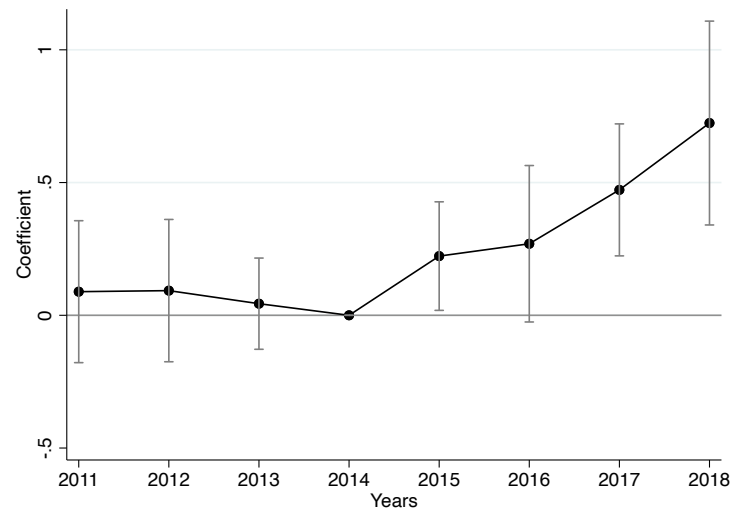

(a.3) Adds dept-year FE and baseline controls

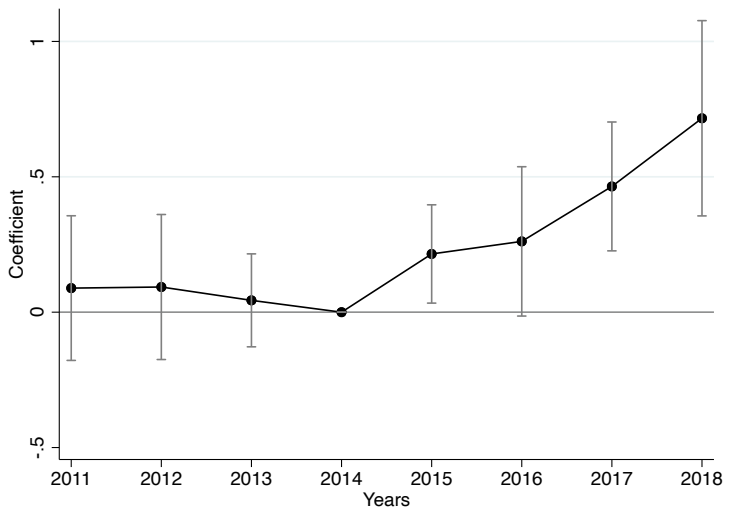

(a.2) Adds dept-year FE

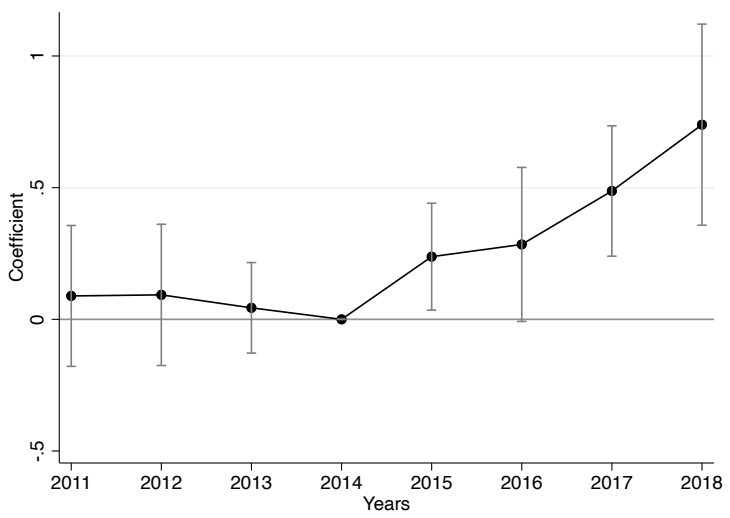

(a.4) Adds dept-year FE, and baseline and illegal activities controls

Notes: These figures present the coefficients from our specification presented in equation (3) for birth rate. Panel (a) includes municipality and year fixed effects, Panel (b) includes municipality and department/year fixed effects, Panel (c) includes municipality and department/year fixed effects, and baseline controls, and Panel (d) includes municipality and department/year fixed effects, and baseline controls and controls associated with violent and illegal activities. We present the point estimates of the regressions and the $95 \%$ confidence interval. 
Figure A.3: Dynamic difference-in-differences for FARC measured over other time windows

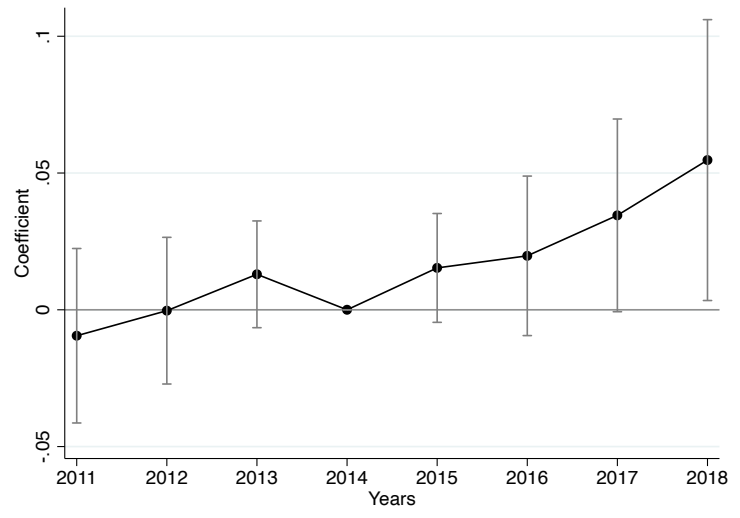

(a.1) Window 2002-2014, dept-year FE

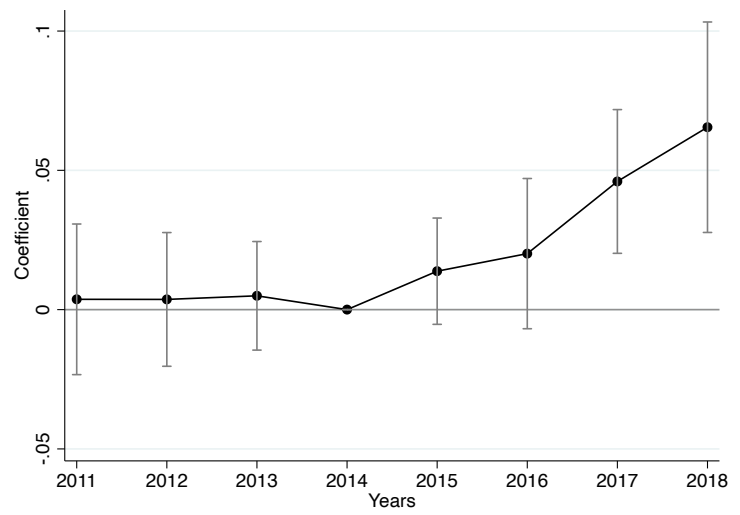

(a.3) Window 2002-2014, dept-year FE

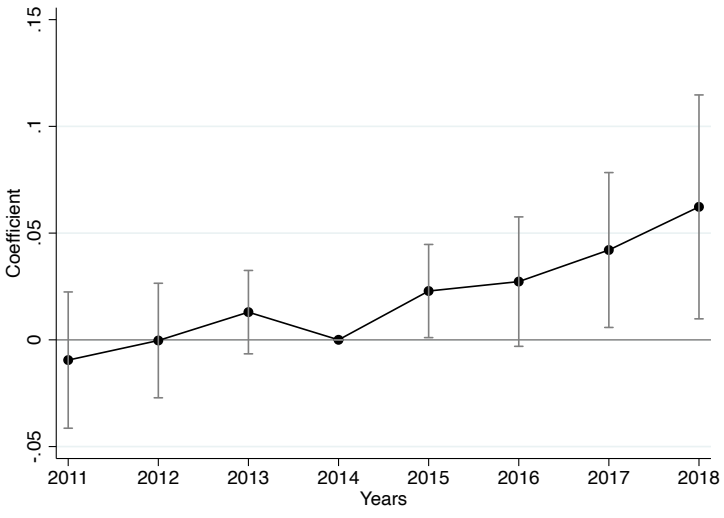

(a.2) Window 2006-2014, dept-year FE, and controls

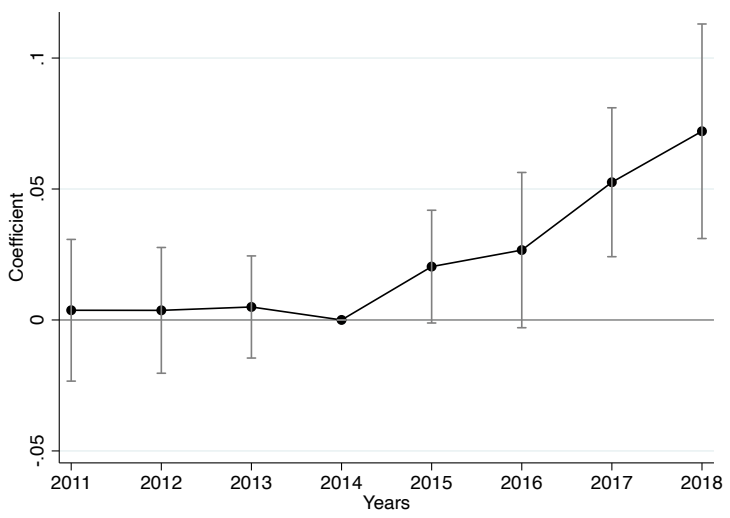

(a.4) Window 2006-2014, dept-year FE, and controls

Notes: These figures present the coefficients from our specification presented in equation (3). Panels A and B (C and D) measure FARC over the years 2002 and 2014 (2006 and 2014) All figures include municipality and department/year fixed effects, and Panels B and D add municipality characteristics interacted with time fixed effects. The dependent variable in all panels is the total fertility rate. We present the point estimates of the regressions and the $95 \%$ confidence interval. 
Figure A.4: Dynamic difference-in-differences for age-specific fertility rates

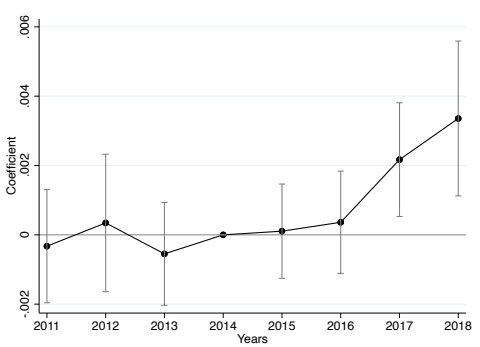

(a.1) Age between 15 and 19

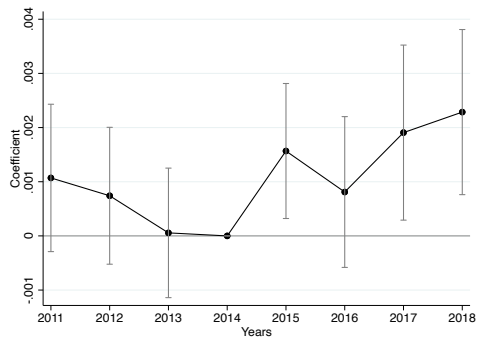

(a.4) Age between 30 and 34

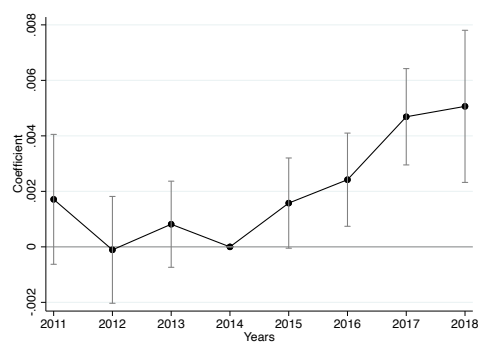

(a.2) Age between 20 and 24

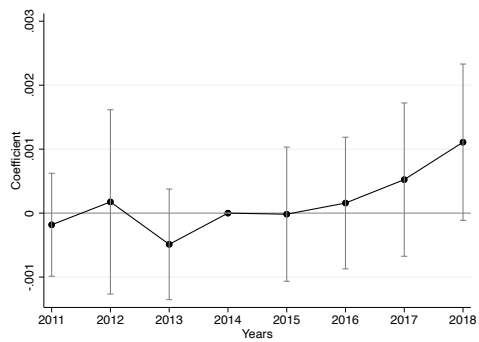

(a.5) Age between 35 and 39

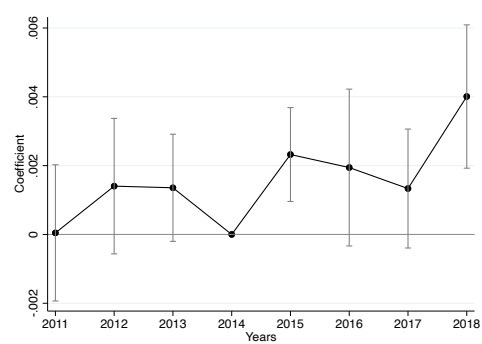

(a.3) Age between 25 and 29

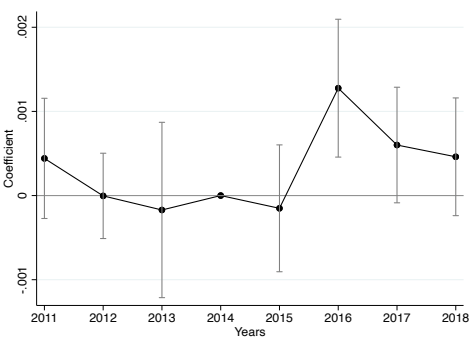

(a.6) Age between 40 and 44

Notes: These figures present the coefficients from our specification presented in equation (3). The dependent variable is age-specific fertility rates. All panels include municipality and department/year fixed effects. We present the point estimates of the regressions and the $95 \%$ confidence interval. 
Figure A.5: Dynamic difference-in-differences for total fertility rate in an extended sample

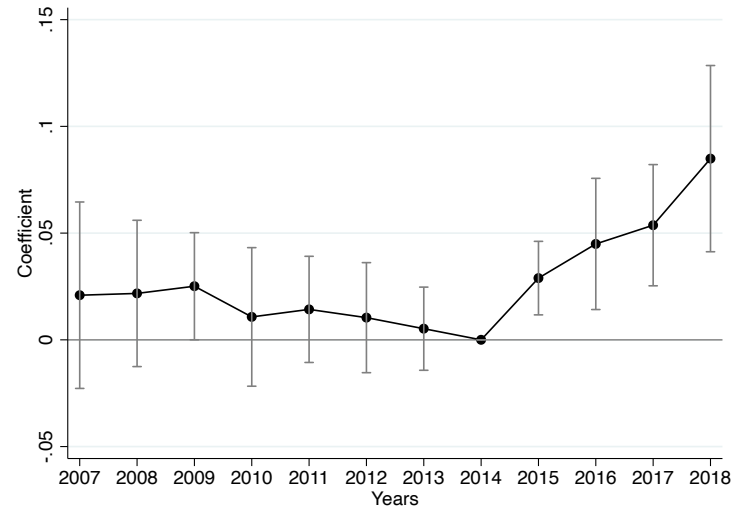

(a.1) Baseline

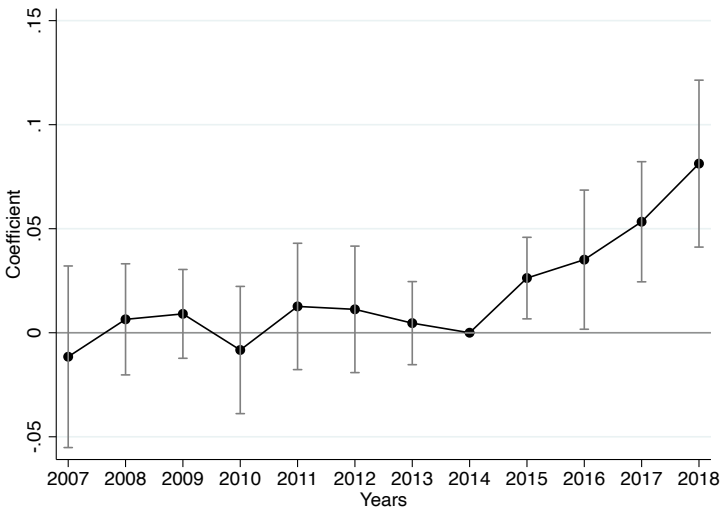

(a.2) Adds dept-year FE

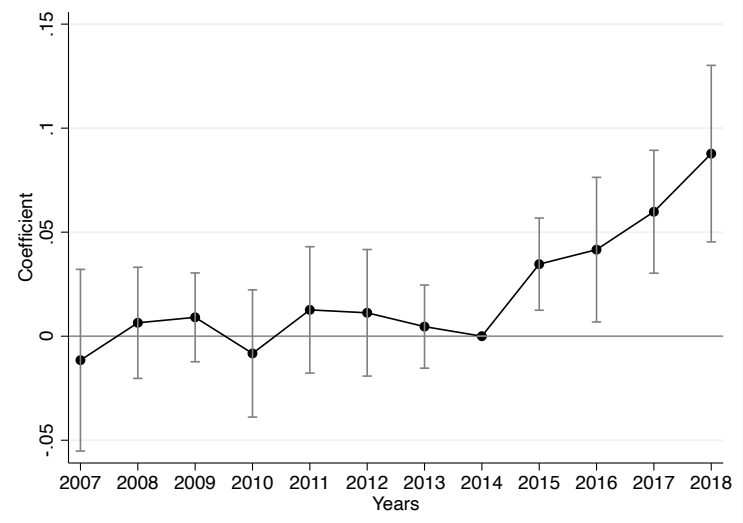

(a.3) Adds dept-year FE and baseline controls

Notes: These figures present the coefficients from our specification presented in equation (3), but for an extended period. Panel (a.1) includes municipality and year fixed effects, Panel (a.2) includes municipality and department/year fixed effects, Panel (a.3) includes municipality and department/year fixed effects, and baseline controls. We present the point estimates of the regressions and the $95 \%$ confidence interval. 
Figure A.6: Dynamic difference-in-differences for heterogeneous effects

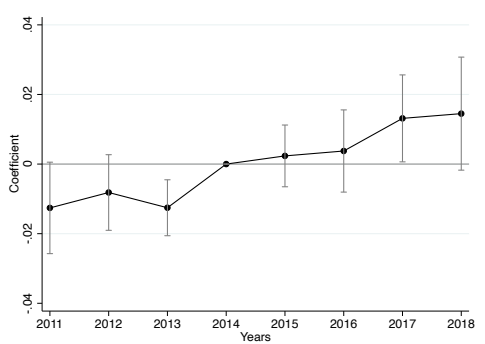

(a.1) Mines victims

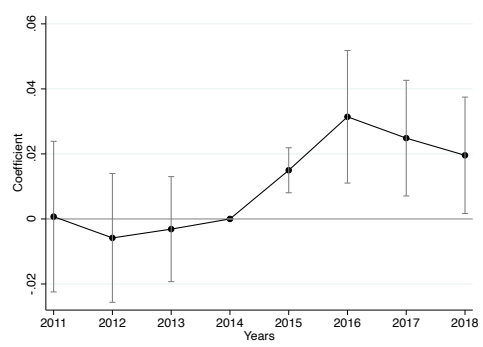

(a.2) Forced displacement

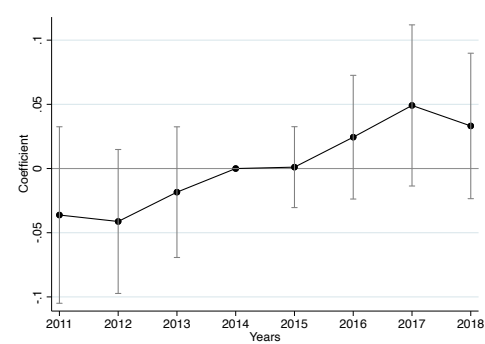

(a.3) Children recruitment

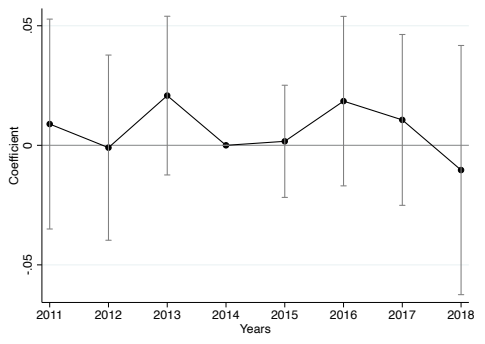

(a.4) Infant mortality

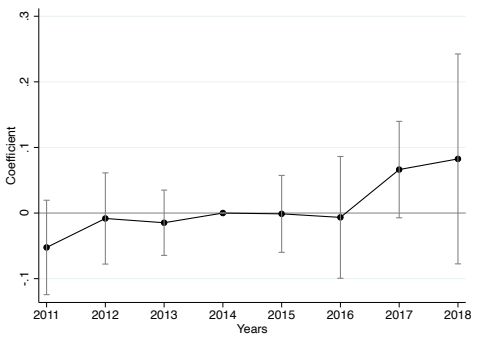

(a.5) ETCR

Notes: These figures present the coefficients from a dynamic version of the specification presented in equation (4). The dependent variable for all panels is the total fertility rate. We present the point estimates of the regressions and the $95 \%$ confidence interval. 
Figure A.7: Dynamic difference-in-differences for infrastructure and operation of the health sector

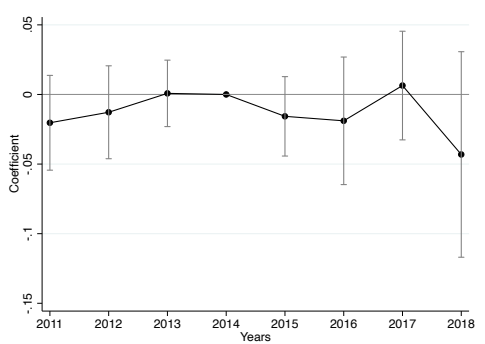

(a.1) Antenatal care visits

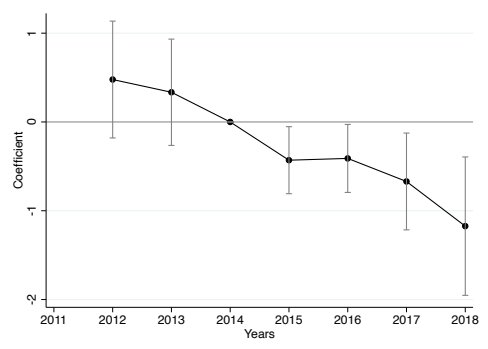

(a.4) Therapeutic support

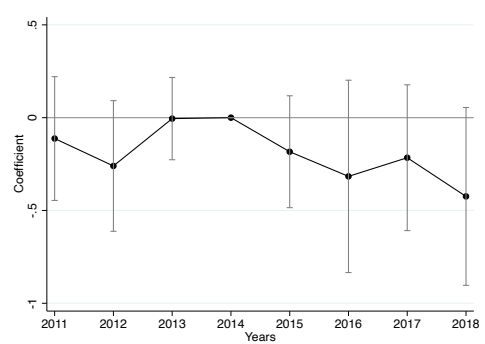

(a.2) Births attended by health professional

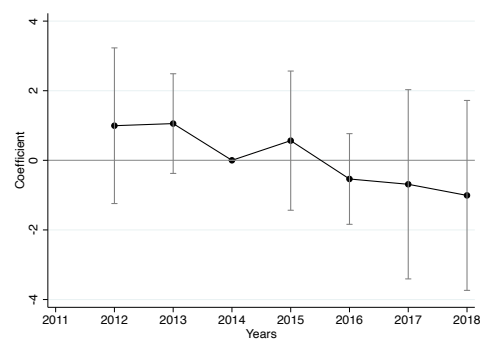

(a.5) Hospital beds

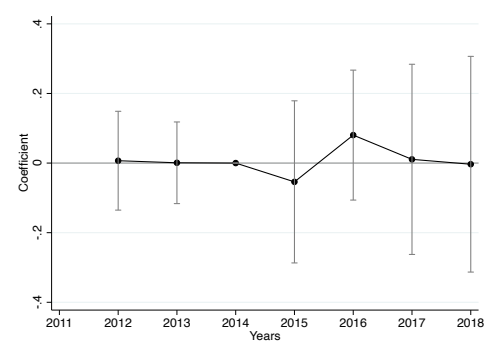

(a.3) Ambulances

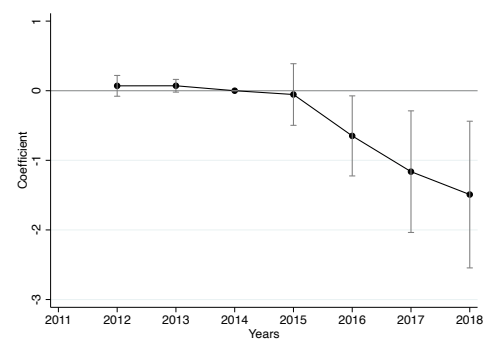

(a.6) Medical wards

Notes: These figures present the coefficients from our specification presented in equation (3). All figures include municipality and department/year fixed effects. The descriptions for each dependent variable are presented in Table 4 . We present the point estimates of the regressions and the $95 \%$ confidence interval. 
Figure A.8: Dynamic difference-in-differences for mother's characteristics

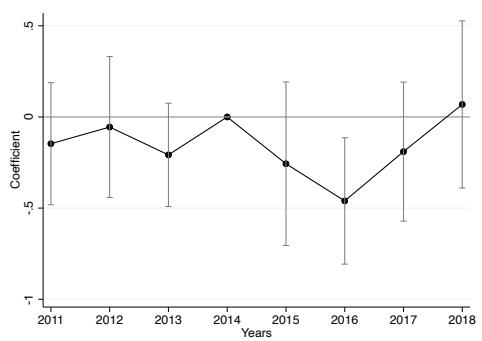

(a.1) First-time mothers

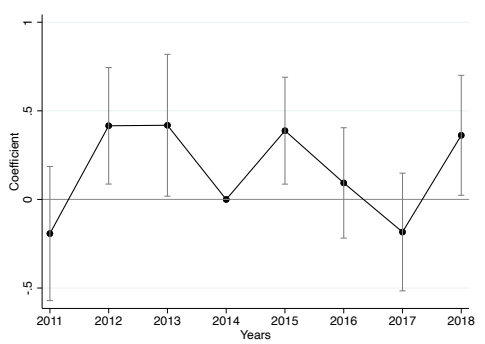

(a.4) First-time mothers: 25-29

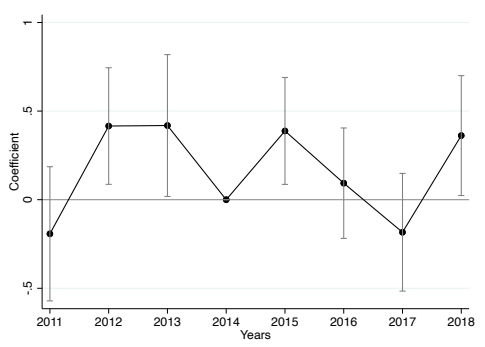

(a.7) Mothers' educ: High school

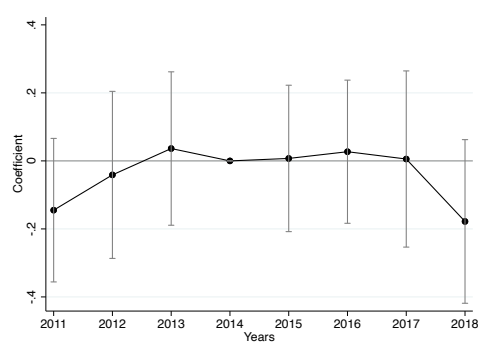

(a.2) First-time mothers: 15-19

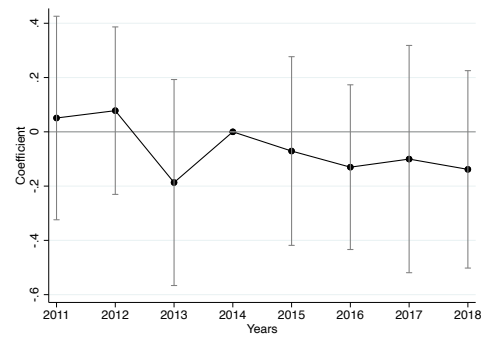

(a.5) First-time mothers: 30-34

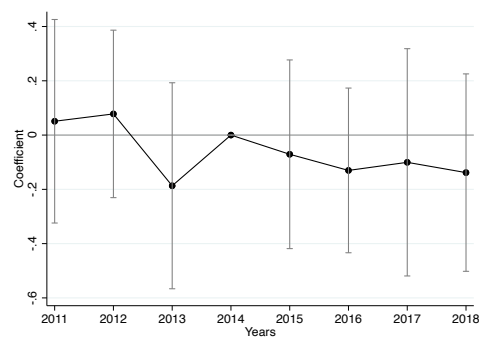

(a.8) Mothers' educ: College or above

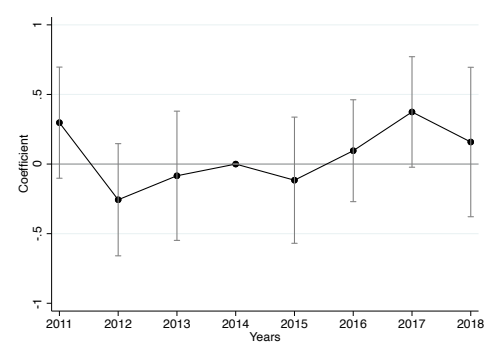

(a.3) First-time mothers: 20-24

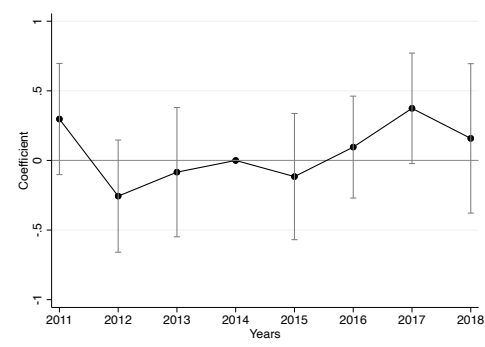

(a.6) Mothers' educ: Secondary or less

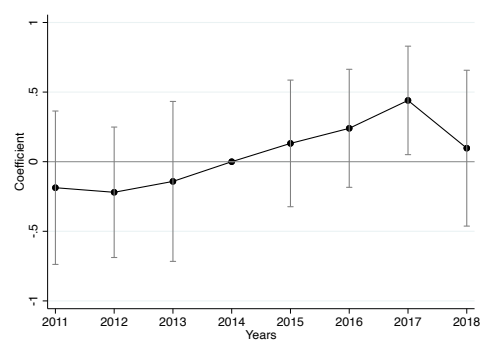

(a.9) Cohabiting parents

Notes: These figures present the coefficients from our specification presented in equation (3). All figures include municipality and department-year fixed effects. The descriptions for each dependent variable are presented in Table A.16 and Table A.17. We present the point estimates of the regressions and the $95 \%$ confidence interval. 
Figure A.9: Dynamic difference-in-differences for neonatal and infant mortality

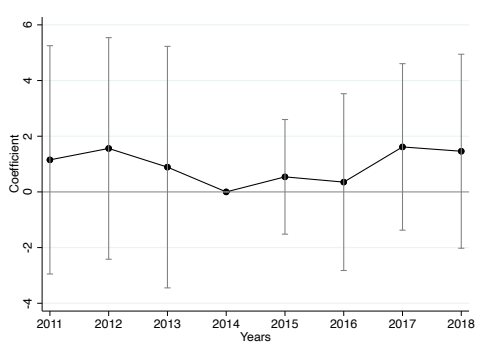

(a.1) Miscarriage rate

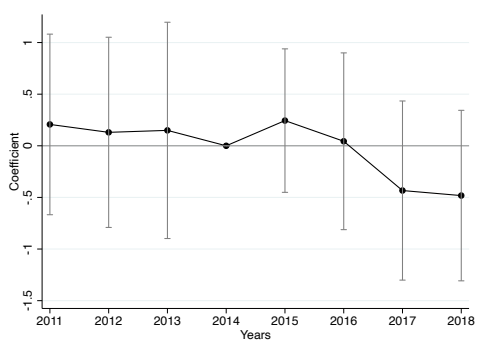

(a.4) Under-five mortality rate

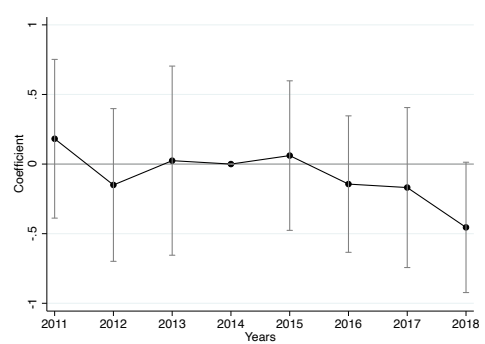

(a.2) Neonatal mortality rate

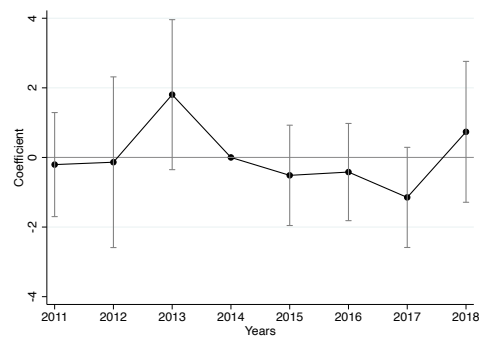

(a.5) Under-five mortality rate due to acute diarrheal disease

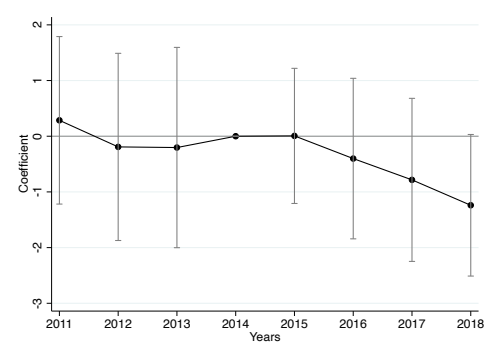

(a.3) Infant mortality rate

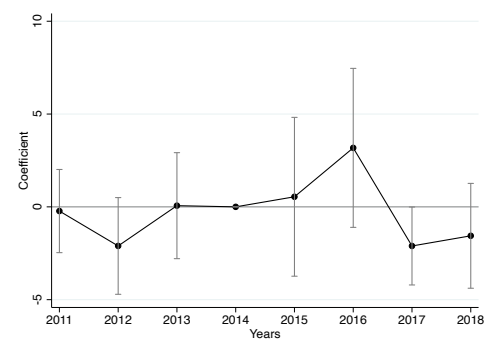

(a.6) Under-five mortality rate due to acute respiratory infection

Notes: These figures present the coefficients from our specification presented in equation (3). All panels include municipality and department/year fixed effects. The descriptions for each dependent variable are presented in Table 5 . We present the point estimates of the regressions and the $95 \%$ confidence interval. 
Figure A.10: Dynamic difference-in-differences for newborn health

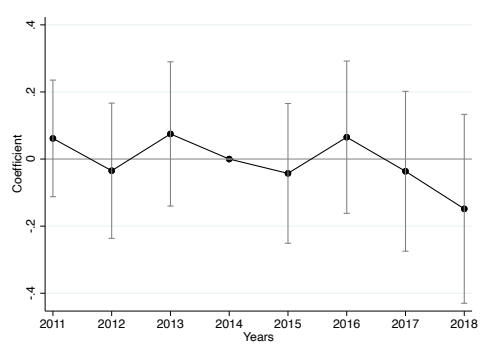

(a.1) Low birth weight

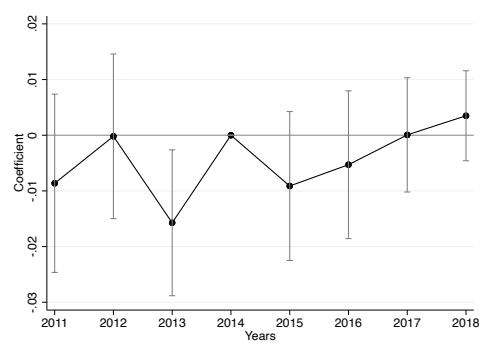

(a.2) Apgar $1 \mathrm{~min}$

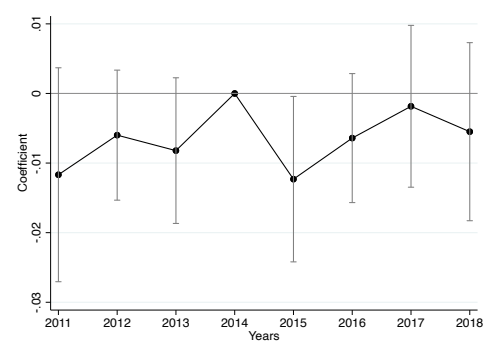

(a.3) Apgar 5 min

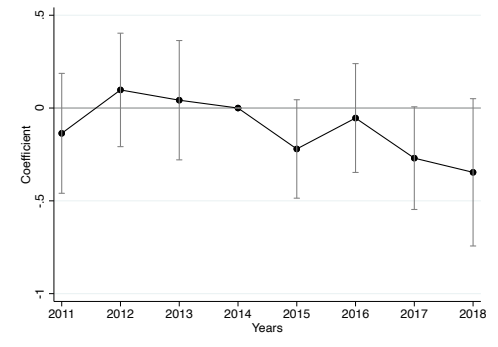

(a.4) Preterm birth

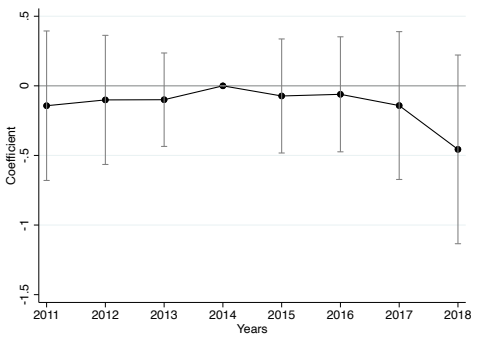

(a.5) C-Section delivery

Notes: These figures present the coefficients from our specification presented in equation (3). All figures include department/year fixed effects. The descriptions for each dependent variable are presented in Table 6 . We present the point estimates of the regressions and the $95 \%$ confidence interval. 
Table A.1: Variables description and sources

\begin{tabular}{|c|c|c|c|}
\hline Variable & Description & Source & \\
\hline \multicolumn{4}{|c|}{ Variables: Total fertility rate and age-specific fertility rate } \\
\hline $\begin{array}{l}\text { Total fertility } \\
\text { rate }\end{array}$ & $\begin{array}{l}\text { Mean number of children a woman would have } \\
\text { by age } 50 \text { if she survived to age } 50 \text { and were sub- } \\
\text { ject, throughout her life, to the age-specific fer- } \\
\text { tility rates observed in each year. It is computed } \\
\text { as the sum of age-specific fertility rates weighted } \\
\text { by the number of years in each age group, di- } \\
\text { vided by } 1,000\end{array}$ & $\begin{array}{l}\text { SISPRO } \\
\text { DANE }\end{array}$ & and \\
\hline $\begin{array}{l}\text { Age-specific } \\
\text { fertility rate }\end{array}$ & $\begin{array}{l}\text { Number of live births to women in the age- } \\
\text { group per } 1,000 \text { population of women in the } \\
\text { same age range }\end{array}$ & $\begin{array}{l}\text { SISPRO } \\
\text { DANE }\end{array}$ & and \\
\hline \multicolumn{4}{|c|}{ Variables: Infrastructure and operation of the health sector } \\
\hline $\begin{array}{l}\text { Antenatal care } \\
\text { visits }\end{array}$ & Average number of antenatal care visits & $\begin{array}{l}\text { SISPRO } \\
\text { DANE }\end{array}$ & and \\
\hline $\begin{array}{l}\text { Births attended } \\
\text { by health pro- } \\
\text { fessional }\end{array}$ & $\begin{array}{l}\text { Number of deliveries attended by doctors, } \\
\text { nurses, health promoters and nursing assistants } \\
\text { per } 100 \text { live births }\end{array}$ & $\begin{array}{l}\text { SISPRO } \\
\text { DANE }\end{array}$ & and \\
\hline Ambulances & $\begin{array}{l}\text { Number of ambulances for every 1,000 inhabi- } \\
\text { tants }\end{array}$ & $\begin{array}{l}\text { REPS } \\
\text { DANE }\end{array}$ & and \\
\hline $\begin{array}{l}\text { Therapeutic } \\
\text { support }\end{array}$ & $\begin{array}{l}\text { Number of therapeutic chairs (hemodialysis } \\
\text { chairs and chemotherapy chairs) for every 1,000 } \\
\text { inhabitants }\end{array}$ & $\begin{array}{l}\text { REPS } \\
\text { DANE }\end{array}$ & and \\
\hline Hospital beds & $\begin{array}{l}\text { Number of hospital beds (adult beds, neonatal } \\
\text { care beds, pediatric beds, mental care beds, drug } \\
\text { dependence beds, chronic patients beds, obstet- } \\
\text { rics beds, Hematopoietic steam cell transplanta- } \\
\text { tion beds) for every 1,000 inhabitants }\end{array}$ & $\begin{array}{l}\text { REPS } \\
\text { DANE }\end{array}$ & and \\
\hline Medical wards & $\begin{array}{l}\text { Number of medical wards (delivery room, pro- } \\
\text { cedure room and operating room) for every } 1,000 \\
\text { inhabitants }\end{array}$ & $\begin{array}{l}\text { REPS } \\
\text { DANE }\end{array}$ & and \\
\hline
\end{tabular}


Variables description and sources, continued from previous page

\begin{tabular}{|c|c|c|c|}
\hline Variable & Description & Source & \\
\hline \multicolumn{4}{|c|}{ Variables: Neonatal, infant mortality and diseases } \\
\hline $\begin{array}{l}\text { Fetal mortality } \\
\text { rate }\end{array}$ & $\begin{array}{l}\text { Number of fetal deaths, regardless of gestational } \\
\text { age, per 1,000 known pregnancies (live births + } \\
\text { fetal deaths) in a year }\end{array}$ & $\begin{array}{l}\text { SISPRO } \\
\text { DANE }\end{array}$ & and \\
\hline $\begin{array}{l}\text { Neonatal mor- } \\
\text { tality rate }\end{array}$ & $\begin{array}{l}\text { Number of deaths of babies under } 28 \text { days per } \\
1,000 \text { live births in a year }\end{array}$ & $\begin{array}{l}\text { SISPRO } \\
\text { DANE }\end{array}$ & and \\
\hline Infant mortality & $\begin{array}{l}\text { Number of deaths of children under } 1 \text { year old } \\
\text { per } 1,000 \text { live births in a year }\end{array}$ & $\begin{array}{l}\text { SISPRO } \\
\text { DANE }\end{array}$ & and \\
\hline $\begin{array}{l}\text { Under-5 mor- } \\
\text { tality }\end{array}$ & $\begin{array}{l}\text { Number of deaths of children under } 5 \text { years old } \\
\text { per } 1,000 \text { live births in a year }\end{array}$ & $\begin{array}{l}\text { SISPRO } \\
\text { DANE }\end{array}$ & and \\
\hline $\begin{array}{l}\text { Under-5 mor- } \\
\text { tality ADD }\end{array}$ & $\begin{array}{l}\text { Number of deaths of children under } 5 \text { years old } \\
\text { due to acute diarrhoeal disease per } 1,000 \text { live } \\
\text { births in a year }\end{array}$ & $\begin{array}{l}\text { SISPRO } \\
\text { DANE }\end{array}$ & and \\
\hline $\begin{array}{l}\text { Under-5 mor- } \\
\text { tality ARI }\end{array}$ & $\begin{array}{l}\text { Number of deaths of children under } 5 \text { years old } \\
\text { due to Acute respiratory infection per } 1,000 \text { live } \\
\text { births }\end{array}$ & $\begin{array}{l}\text { SISPRO } \\
\text { DANE }\end{array}$ & and \\
\hline \multicolumn{4}{|c|}{ Variables: Newborn health } \\
\hline $\begin{array}{l}\text { Low } \\
\text { weight }\end{array}$ & $\begin{array}{l}\text { percentage of live births with weight less than } \\
2,500 \text { grams }\end{array}$ & SISPRO & \\
\hline APGAR $1 \mathrm{~min}$ & Mean APGAR test after 1 minute & SISPRO & \\
\hline APGAR $5 \mathrm{~min}$ & Mean APGAR test after 5 minutes & SISPRO & \\
\hline Preterm birth & $\begin{array}{l}\text { Number of live births who were born alive be- } \\
\text { fore } 37 \text { gestational weeks per } 100 \text { live births }\end{array}$ & $\begin{array}{l}\text { SISPRO } \\
\text { DANE }\end{array}$ & and \\
\hline $\begin{array}{l}\text { C-Section deliv- } \\
\text { ery }\end{array}$ & $\begin{array}{l}\text { Number of babies delivered by caesarean per } 100 \\
\text { live births }\end{array}$ & $\begin{array}{l}\text { SISPRO } \\
\text { DANE }\end{array}$ & and \\
\hline \multicolumn{4}{|c|}{ Variables: Marriage } \\
\hline Marriage & Share of the population ever married & $\begin{array}{l}2005 \text { and } \\
\text { Colombian } \\
\text { Census }\end{array}$ & 2018 \\
\hline
\end{tabular}


Variables description and sources, continued from previous page

\begin{tabular}{|c|c|c|}
\hline Variable & Description & Source \\
\hline \multicolumn{3}{|c|}{ Variables: Control variables } \\
\hline Rural share & $\begin{array}{l}\text { percentage of the population outside the urban } \\
\text { centre in the municipality. }\end{array}$ & $\begin{array}{l}\text { CEDE, based } \\
\text { DANE informa- } \\
\text { tion }\end{array}$ \\
\hline $\begin{array}{l}\text { Distance to cap- } \\
\text { ital }\end{array}$ & $\begin{array}{l}\text { Straight line distance to the capital of the depart- } \\
\text { ment in which the municipality is located. }\end{array}$ & $\begin{array}{l}\text { CEDE, based } \\
\text { on Agustin } \\
\text { Codazzi } \quad \text { Ge- } \\
\text { ographic } \\
\text { Institute in- } \\
\text { formation }\end{array}$ \\
\hline $\begin{array}{l}\text { Antipersonnel } \\
\text { landmines } \\
\text { victims }\end{array}$ & $\begin{array}{l}\text { Standardize measure of the number of victims } \\
\text { related to antipersonnel landmines. }\end{array}$ & $\begin{array}{l}\text { Office of the } \\
\text { High Com- } \\
\text { missioner for } \\
\text { Peace - De- } \\
\text { contaminate } \\
\text { Colombia }\end{array}$ \\
\hline Poverty index & $\begin{array}{l}\text { percentage of the population in poverty accord- } \\
\text { ing to the multidimensional index. }\end{array}$ & $\begin{array}{l}\text { CEDE, based on } \\
\text { DANE informa- } \\
\text { tion }\end{array}$ \\
\hline Ln population & $\begin{array}{l}\text { Demographic projections based on the results of } \\
\text { the } 2005 \text { Census and the Census Reconciliation } \\
1985 \text { - 2005, as well as the analyses on the be- } \\
\text { havior of the variables determining the demo- } \\
\text { graphic evolution. }\end{array}$ & DANE \\
\hline Coca suitability & $\begin{array}{l}\text { Based on household survey and municipal geo- } \\
\text { graphic and weather characteristics. }\end{array}$ & $\begin{array}{l}\text { Mejía and } \operatorname{Re}- \\
\text { strepo (2015) }\end{array}$ \\
\hline Gold suitability & $\begin{array}{l}\text { Measure of geochemical anomalies of the munic- } \\
\text { ipal soil associated with the presence of gold de- } \\
\text { posits. }\end{array}$ & $\begin{array}{l}\text { Idrobo et al. } \\
(2014)\end{array}$ \\
\hline \multicolumn{3}{|c|}{ Variables: Exposure to FARC violence } \\
\hline $\begin{array}{l}\text { FARC and other } \\
\text { armed groups } \\
\text { attacks }\end{array}$ & $\begin{array}{l}\text { Total number of FARC attacks per } 10,000 \text { inhabi- } \\
\text { tants in the municipality, from } 2011 \text { to } 2014 \text {, stan- } \\
\text { dardised by the mean and standard deviation } \\
\text { from } 2014 \text {. Attacks are defined according to Re- } \\
\text { strepo et al. (2003): a violent event in which there } \\
\text { is no direct, armed combat between two groups. }\end{array}$ & $\begin{array}{l}\text { Restrepo et al. } \\
\text { (2003), updated } \\
\text { until } 2014 \text { by } \\
\text { Universidad } \\
\text { del Rosario }\end{array}$ \\
\hline
\end{tabular}

Continued on next page 
Variables description and sources, continued from previous page

\begin{tabular}{|c|c|c|}
\hline Variable & Description & Source \\
\hline \multicolumn{3}{|c|}{ Variables: Municipality characteristics } \\
\hline $\begin{array}{l}\text { Forced dis- } \\
\text { placement } \\
\text { (returnees) }\end{array}$ & $\begin{array}{l}\text { Population expelled in a municipality due to } \\
\text { forced displacement that returned to their origin } \\
\text { municipality. }\end{array}$ & $\begin{array}{l}\text { Victims' } \\
\text { istry }\end{array}$ \\
\hline Child soldering & $\begin{array}{l}\text { Number of children forcibly recruited by munic- } \\
\text { ipality. }\end{array}$ & $\begin{array}{l}\text { Centro } \\
\text { cional } \\
\text { Memoria } \\
\text { Histórica } \\
(\mathrm{CNMH})\end{array}$ \\
\hline ETCR & $\begin{array}{l}\text { Dummy that takes the value for municipalities } \\
\text { with Territorial Training and Reincorporation } \\
\text { Spaces, which are the places created to train the } \\
\text { former FARC members for their reincorporation } \\
\text { into civil life. }\end{array}$ & $\begin{array}{l}\text { Agency for } \\
\text { Reincorpo- } \\
\text { ration and } \\
\text { Standardization }\end{array}$ \\
\hline \multicolumn{3}{|c|}{ Variables: 2018 Census } \\
\hline $\begin{array}{l}\text { Migrant } 5 \text { years } \\
\text { ago }\end{array}$ & $\begin{array}{l}\text { An individual that was living in different mu- } \\
\text { nicipality from the one where it was surveyed } 5 \\
\text { years ago. }\end{array}$ & 2018 Census \\
\hline $\begin{array}{l}\text { Migrant } 1 \text { year } \\
\text { ago }\end{array}$ & $\begin{array}{l}\text { An individual that was living in different mu- } \\
\text { nicipality from the one where it was surveyed } 1 \\
\text { years ago. }\end{array}$ & 2018 Census \\
\hline \multicolumn{3}{|c|}{ Variables: Mother characteristics } \\
\hline $\begin{array}{l}\text { Cohabiting par- } \\
\text { ents }\end{array}$ & $\begin{array}{l}\text { Proportion of births from mothers who report to } \\
\text { be married or living with the father of the new- } \\
\text { born }\end{array}$ & $\begin{array}{l}\text { Vital statistics } \\
\text { (DANE) }\end{array}$ \\
\hline $\begin{array}{l}\text { First time moth- } \\
\text { ers }\end{array}$ & $\begin{array}{l}\text { Proportion of births from mothers who were } \\
\text { pregnant for the first time }\end{array}$ & $\begin{array}{l}\text { Vital statistics } \\
\text { (DANE) }\end{array}$ \\
\hline $\begin{array}{l}\text { Educational } \\
\text { level }\end{array}$ & $\begin{array}{l}\text { Proportion of births from mothers according to } \\
\text { the self reported education level. Secondary or } \\
\text { less corresponds to 'Secundaria Media (grado } \\
\text { 9)'; High School to 'Bachillerato'; and College } \\
\text { and above to 'Tecnico, tecnologico, profesional' } \\
\text { tertiary education degreees, and any subsequent } \\
\text { academic level }\end{array}$ & $\begin{array}{l}\text { Vital statistics } \\
(\mathrm{DANE})\end{array}$ \\
\hline
\end{tabular}


Table A.2: Summary Statistics

\begin{tabular}{|c|c|c|c|c|c|c|}
\hline & $(1)$ & $(2)$ & (3) & (4) & (5) & (6) \\
\hline & Mean & $\begin{array}{c}\text { Mean } \\
\text { unweighted }\end{array}$ & Standard deviation & Median & Min & Max \\
\hline Total fertility rate & 1.90 & 1.61 & 0.59 & 1.83 & 0.00 & 8.06 \\
\hline ASFR for girls aged 15-19 & 82.27 & 67.46 & 26.18 & 80.70 & 0.00 & 208.33 \\
\hline ASFR for women aged $20-24$ & 104.26 & 84.60 & 34.04 & 100.11 & 0.00 & 275.00 \\
\hline ASFR for women aged 25-29 & 86.55 & 71.98 & 30.41 & 81.75 & 0.00 & 379.31 \\
\hline ASFR for women aged 30-34 & 64.45 & 55.58 & 23.37 & 61.48 & 0.00 & 450.00 \\
\hline ASFR for women aged 35-39 & 35.40 & 30.88 & 14.65 & 33.33 & 0.00 & 200.00 \\
\hline ASFR for women aged $40-44$ & 10.95 & 10.32 & 6.44 & 9.80 & 0.00 & 100.00 \\
\hline ASFR for women aged $45-49$ & 1.77 & 1.02 & 2.54 & 1.04 & 0.00 & 71.43 \\
\hline Total births per municipality & 981.77 & 297.96 & 974.07 & 582.00 & 0.00 & 4678.00 \\
\hline Birth rate per 10,000 individuals & 15.47 & 12.42 & 4.95 & 14.96 & 0.00 & 49.00 \\
\hline Average of antenatal care visits & 5.78 & 5.68 & 0.95 & 5.84 & 0.00 & 8.51 \\
\hline Births attended by health professional & 98.08 & 97.26 & 5.58 & 99.59 & 0.00 & 100.00 \\
\hline Births attended by traditional midwife & 1.92 & 2.74 & 5.58 & 0.41 & 0.00 & 100.00 \\
\hline Fetal mortality rate & 44.32 & 43.02 & 40.33 & 27.47 & 0.00 & 1000.00 \\
\hline Neonatal mortality rate & 7.61 & 7.54 & 5.76 & 6.99 & 0.00 & 136.36 \\
\hline Neonatal mortality above 10 & 0.24 & 0.28 & 0.43 & 0.00 & 0.00 & 1.00 \\
\hline Infant mortality rate & 24.77 & 25.23 & 16.56 & 22.81 & 0.00 & 545.45 \\
\hline Infant mortality above 18 & 0.67 & 0.56 & 0.47 & 1.00 & 0.00 & 1.00 \\
\hline Under-five mortality & 15.40 & 16.07 & 10.04 & 13.99 & 0.00 & 318.18 \\
\hline ADD mortality in children under 5 & 4.46 & 3.93 & 19.27 & 0.00 & 0.00 & 830.26 \\
\hline ARI mortality in children under 5 & 15.32 & 12.89 & 28.46 & 0.00 & 0.00 & 581.40 \\
\hline Infectious and parasitic diseases rate & 117.19 & 91.65 & 94.86 & 97.85 & 0.00 & 2418.51 \\
\hline Perc. of low weight at birth ( $<2500$ grs $)$ & 7.76 & 7.79 & 2.43 & 7.51 & 0.00 & 100.00 \\
\hline Mean APGAR Test 1 Minute & 8.20 & 8.15 & 0.26 & 8.20 & 4.00 & 9.12 \\
\hline Mean APGAR Test 5 Minutes & 9.59 & 9.58 & 0.21 & 9.62 & 6.00 & 10.00 \\
\hline Preterm birth ( $<37$ weeks) & 17.34 & 17.08 & 4.20 & 17.17 & 0.00 & 100.00 \\
\hline Caesarean births & 39.89 & 35.20 & 14.29 & 37.90 & 0.00 & 100.00 \\
\hline Ambulances & 5.80 & 2.29 & 9.33 & 3.00 & 0.00 & 71.00 \\
\hline Therapeutic support & 1.06 & 0.13 & 5.30 & 0.00 & 0.00 & 73.00 \\
\hline Hospital Beds & 80.41 & 21.19 & 114.99 & 24.00 & 0.00 & 564.00 \\
\hline Medical wards & 5.08 & 1.69 & 6.76 & 2.00 & 0.00 & 39.00 \\
\hline FARC attacks per 10,000 inhab & 0.11 & 0.12 & 0.47 & 0.00 & 0.00 & 9.80 \\
\hline Victims of anti-personnel mines & 7.18 & 4.88 & 10.93 & 3.00 & 1.00 & 52.00 \\
\hline Rural share & 0.42 & 0.59 & 0.25 & 0.41 & 0.02 & 1.00 \\
\hline Distance to capital & 81.57 & 83.32 & 63.45 & 65.63 & 0.00 & 493.08 \\
\hline Poverty index & 64.97 & 70.35 & 19.39 & 68.77 & 14.27 & 100.00 \\
\hline Population & 59,949 & 21,434 & 52,582 & 38,498 & 298 & 217,343 \\
\hline Municipalities & & 1092 & & & & \\
\hline
\end{tabular}

Notes: This table presents summary statistics for the main variables of interest before 2014. All columns present weighted (by the number of live births between 2011 to 2014 for each age group) versions of the summary statistics, except for Column 2. 
Table A.3: Municipality characteristics by exposure to FARC violence before the ceasefire

\begin{tabular}{|c|c|c|c|}
\hline & \multirow[b]{2}{*}{$\begin{array}{l}\text { Avg without } \\
\text { FARC }\end{array}$} & \multicolumn{2}{|c|}{$\begin{array}{l}(2) \\
\text { Exposure to FARC } \\
\text { violence }\end{array}$} \\
\hline & & Continuous & Discrete \\
\hline Total fertility rate & $\begin{array}{c}1.88 \\
(0.57)\end{array}$ & $\begin{array}{c}0.01 \\
(0.01)\end{array}$ & $\begin{array}{c}0.11 \\
(0.07)\end{array}$ \\
\hline ASFR for girls aged 15-19 & $\begin{array}{l}81.21 \\
(26.19)\end{array}$ & $\begin{array}{l}2.11^{* * *} \\
(0.53)\end{array}$ & $\begin{array}{l}6.95^{* * *} \\
(1.90)\end{array}$ \\
\hline ASFR for women aged 20-24 & $\begin{array}{l}104.05 \\
(33.83)\end{array}$ & $\begin{array}{c}-0.81 \\
(0.79)\end{array}$ & $\begin{array}{c}1.58 \\
(3.51)\end{array}$ \\
\hline ASFR for women aged 25-29 & $\begin{array}{c}86.41 \\
(30.06)\end{array}$ & $\begin{array}{l}-1.55^{* *} \\
(0.62)\end{array}$ & $\begin{array}{c}1.07 \\
(3.75)\end{array}$ \\
\hline ASFR for women aged 30-34 & $\begin{array}{c}64.09 \\
(22.39)\end{array}$ & $\begin{array}{c}-0.63 \\
(0.43)\end{array}$ & $\begin{array}{c}2.78 \\
(3.38)\end{array}$ \\
\hline ASFR for women aged 35-39 & $\begin{array}{c}34.70 \\
(13.91)\end{array}$ & $\begin{array}{l}0.76^{* * *} \\
(0.29)\end{array}$ & $\begin{array}{l}5.20^{* * *} \\
(1.95)\end{array}$ \\
\hline ASFR for women aged 40-44 & $\begin{array}{l}10.58 \\
(6.32)\end{array}$ & $\begin{array}{l}0.70^{* * * *} \\
(0.17)\end{array}$ & $\begin{array}{l}2.77^{* * * *} \\
(0.64)\end{array}$ \\
\hline ASFR for women aged $45-49$ & $\begin{array}{c}1.77 \\
(2.65)\end{array}$ & $\begin{array}{c}0.03 \\
(0.06)\end{array}$ & $\begin{array}{l}-0.03 \\
(0.14)\end{array}$ \\
\hline Average of antenatal care visits & $\begin{array}{l}5.85 \\
(0.94)\end{array}$ & $\begin{array}{l}-0.19 * * * \\
(0.02)\end{array}$ & $\begin{array}{l}-0.52^{* * *} \\
(0.06)\end{array}$ \\
\hline Births attended by health professional & $\begin{array}{l}98.28 \\
(5.71)\end{array}$ & $\begin{array}{l}-0.81^{* * *} \\
(0.12)\end{array}$ & $\begin{array}{l}-1.42^{* * * *} \\
(0.30)\end{array}$ \\
\hline Births attended by traditional midwife & $\begin{array}{c}1.72 \\
(5.71)\end{array}$ & $\begin{array}{l}0.81^{* * *} \\
(0.12)\end{array}$ & $\begin{array}{l}1.42^{* * * *} \\
(0.30)\end{array}$ \\
\hline Neonatal mortality rate & $\begin{array}{c}7.42 \\
(5.77)\end{array}$ & $\begin{array}{l}0.33^{* * *} \\
(0.12)\end{array}$ & $\begin{array}{l}1.32^{* * * *} \\
(0.34)\end{array}$ \\
\hline Neonatal mortality above 10 & $\begin{array}{c}0.23 \\
(0.42)\end{array}$ & $\begin{array}{l}0.03^{* *} \\
(0.01)\end{array}$ & $\begin{array}{l}0.08^{*} \\
(0.04)\end{array}$ \\
\hline Infant mortality rate & $\begin{array}{c}24.19 \\
(16.57)\end{array}$ & $\begin{array}{l}1.25^{* * *} \\
(0.35)\end{array}$ & $\begin{array}{l}4.14^{* * * *} \\
(0.92)\end{array}$ \\
\hline Infant mortality above 18 & $\begin{array}{c}0.65 \\
(0.48)\end{array}$ & $\begin{array}{l}0.03^{* *} \\
(0.01)\end{array}$ & $\begin{array}{l}0.15^{* * * *} \\
(0.03)\end{array}$ \\
\hline Under-five mortality & $\begin{array}{c}14.99 \\
(10.02)\end{array}$ & $\begin{array}{l}0.88^{* * * *} \\
(0.21)\end{array}$ & $\begin{array}{l}2.96^{* * * *} \\
(0.55)\end{array}$ \\
\hline ADD mortality in children under 5 & $\begin{array}{c}4.20 \\
(20.01)\end{array}$ & $\begin{array}{l}0.70^{*} \\
(0.41)\end{array}$ & $\begin{array}{l}1.85^{* * *} \\
(0.86)\end{array}$ \\
\hline ARI mortality in children under 5 & $\begin{array}{l}15.06 \\
(29.24)\end{array}$ & $\begin{array}{c}0.83 \\
(0.58)\end{array}$ & $\begin{array}{l}1.82 \\
(1.66)\end{array}$ \\
\hline Infectious and parasitic diseases rate & $\begin{array}{l}113.59 \\
(90.73)\end{array}$ & $\begin{array}{l}3.90 \\
(2.99)\end{array}$ & $\begin{array}{c}25.85^{* * * *} \\
(9.26)\end{array}$ \\
\hline Percentage of low weight at birth ( $<2500$ grs) & $\begin{array}{l}7.86 \\
(2.51)\end{array}$ & $\begin{array}{l}-0.24^{* * *} \\
(0.04)\end{array}$ & $\begin{array}{l}-0.71^{* * *} \\
(0.13)\end{array}$ \\
\hline Mean APGAR Test 1 Minute & $\begin{array}{c}8.18 \\
(0.26)\end{array}$ & $\begin{array}{c}0.03^{* * * *} \\
(0.01)\end{array}$ & $\begin{array}{l}0.11^{* * * *} \\
(0.02)\end{array}$ \\
\hline Mean APGAR Test 5 Minutes & $\begin{array}{c}9.58 \\
(0.21)\end{array}$ & $\begin{array}{l}0.02^{* * *} \\
(0.00)\end{array}$ & $\begin{array}{l}0.07^{* * * *} \\
(0.02)\end{array}$ \\
\hline Preterm birth (<37 weeks) & $\begin{array}{l}17.55 \\
(4.25)\end{array}$ & $\begin{array}{c}-0.40^{* * * *} \\
(0.07)\end{array}$ & $\begin{array}{l}-1.54^{* * *} \\
(0.27)\end{array}$ \\
\hline Caesarean births & $\begin{array}{c}40.76 \\
(14.46)\end{array}$ & $\begin{array}{c}-1.89^{* * * *} \\
(0.32)\end{array}$ & $\begin{array}{l}-6.25^{* * *} \\
(1.17)\end{array}$ \\
\hline Ambulances & $\begin{array}{l}5.87 \\
(9.91)\end{array}$ & $\begin{array}{c}-0.50^{* * * *} \\
(0.17)\end{array}$ & $\begin{array}{l}-0.47 \\
(0.76)\end{array}$ \\
\hline Therapeutic support & $\begin{array}{c}0.89 \\
(4.14)\end{array}$ & $\begin{array}{c}-0.15^{* *} \\
(0.08)\end{array}$ & $\begin{array}{l}1.23 \\
(1.26)\end{array}$ \\
\hline Hospital Beds & $\begin{array}{c}80.95 \\
(119.47)\end{array}$ & $\begin{array}{c}-11.96^{* * * *} \\
(2.01)\end{array}$ & $\begin{array}{c}-3.87 \\
(11.75)\end{array}$ \\
\hline Medical wards & $\begin{array}{c}5.06 \\
(7.02)\end{array}$ & $\begin{array}{c}-0.67^{* * * *} \\
(0.12)\end{array}$ & $\begin{array}{c}0.08 \\
(0.70)\end{array}$ \\
\hline Victims of anti-personnel mines & $\begin{array}{c}3.61 \\
(5.29)\end{array}$ & $\begin{array}{l}1.12^{* *} \\
(0.43)\end{array}$ & $\begin{array}{l}6.27^{* * *} \\
(2.09)\end{array}$ \\
\hline Rural share & $\begin{array}{c}0.41 \\
(0.25)\end{array}$ & $\begin{array}{l}0.04^{* * *} \\
(0.00)\end{array}$ & $\begin{array}{l}0.07^{* * * *} \\
(0.02)\end{array}$ \\
\hline Distance to capital & $\begin{array}{c}79.31 \\
(62.74)\end{array}$ & $\begin{array}{l}4.47^{* * * *} \\
(1.57)\end{array}$ & $\begin{array}{l}16.23^{* *} \\
(6.80)\end{array}$ \\
\hline Poverty index & $\begin{array}{c}63.69 \\
(19.89)\end{array}$ & $\begin{array}{l}3.33^{* * * *} \\
(0.43)\end{array}$ & $\begin{array}{l}9.19^{* * * *} \\
(1.23)\end{array}$ \\
\hline Ln population & $\begin{array}{c}10.52 \\
(0.98)\end{array}$ & $\begin{array}{c}-0.06^{* * *} \\
(0.02)\end{array}$ & $\begin{array}{l}0.28^{* * * *} \\
(0.08)\end{array}$ \\
\hline
\end{tabular}

Notes: This table presents univariate regressions based on municipality characteristics before the ceasefire. Column 1 presents the average of each variable before the ceasefire for municipalities non-exposed to FARC violence (without any violent event by FARC between 2011 and 2014). Columns 2 and 3 present estimated coefficients and standard errors from univariate regressions for the continuous and discrete treatment. 
Table A.4: Adding municipality-level trends

\begin{tabular}{|c|c|c|c|c|}
\hline & $(1)$ & $(2)$ & (3) & $(4)$ \\
\hline & \multicolumn{4}{|c|}{ Total Fertility Rate } \\
\hline & \multicolumn{2}{|c|}{ Main sample } & \multicolumn{2}{|c|}{ Extended sample } \\
\hline Cease $\times$ FARC & $\begin{array}{l}0.02^{* *} \\
(0.01)\end{array}$ & $\begin{array}{l}0.02^{* *} \\
(0.01)\end{array}$ & $\begin{array}{l}0.03^{* *} \\
(0.01)\end{array}$ & $\begin{array}{l}0.03^{* *} \\
(0.01)\end{array}$ \\
\hline Observations & 8,736 & 8,736 & 15,187 & 15,187 \\
\hline R-squared & 0.947 & 0.948 & 0.890 & 0.891 \\
\hline Municipality FE & Yes & Yes & Yes & Yes \\
\hline Dept-Year FE & Yes & Yes & Yes & Yes \\
\hline Controls & No & Yes & No & Yes \\
\hline Municipalities & 1092 & 1092 & 1090 & 1090 \\
\hline Mean Dep. Var. & 1.551 & 1.551 & 1.683 & 1.683 \\
\hline Std. Dev. Dep. Var. & 0.598 & 0.598 & 0.613 & 0.613 \\
\hline
\end{tabular}

\begin{abstract}
Notes: This table presents the results from an augmented version of the main specification in equation (2) that adds municipality-level linear trends. In columns 1 and 2 ( 3 and 4), the estimation sample is 2011-2018 (2007-2018). All regressions are weighted by the number of live births between 2011 to 2014 for each age group. Cease is a dummy that takes the value for the period after 2014 . FARC is a continuous measure of the total number of FARC attacks over 10,000 inhabitants from 2011 to 2014, and is standardized by the mean and standard deviation to ease interpretation. Total Fertility Rate is computed as the sum of age-specific fertility rates weighted by the number of years in each age group, divided by 1,000. Columns 2 and 4 add predetermined municipal controls interacted with the ceasefire dummy. These controls include infant mortality rate, number of victims related to anti-personnel mines, share of rural population, distance to the department capital, poverty index, and logarithm of the population in 2010. Clustered robust standard errors at the municipality level are presented in parenthesis. ${ }^{*} p$ is significant at the $10 \%$ level, ${ }^{* *} p$ is significant at the $5 \%$ level, ${ }^{* * *} p$ is significant at the $1 \%$ level.
\end{abstract}



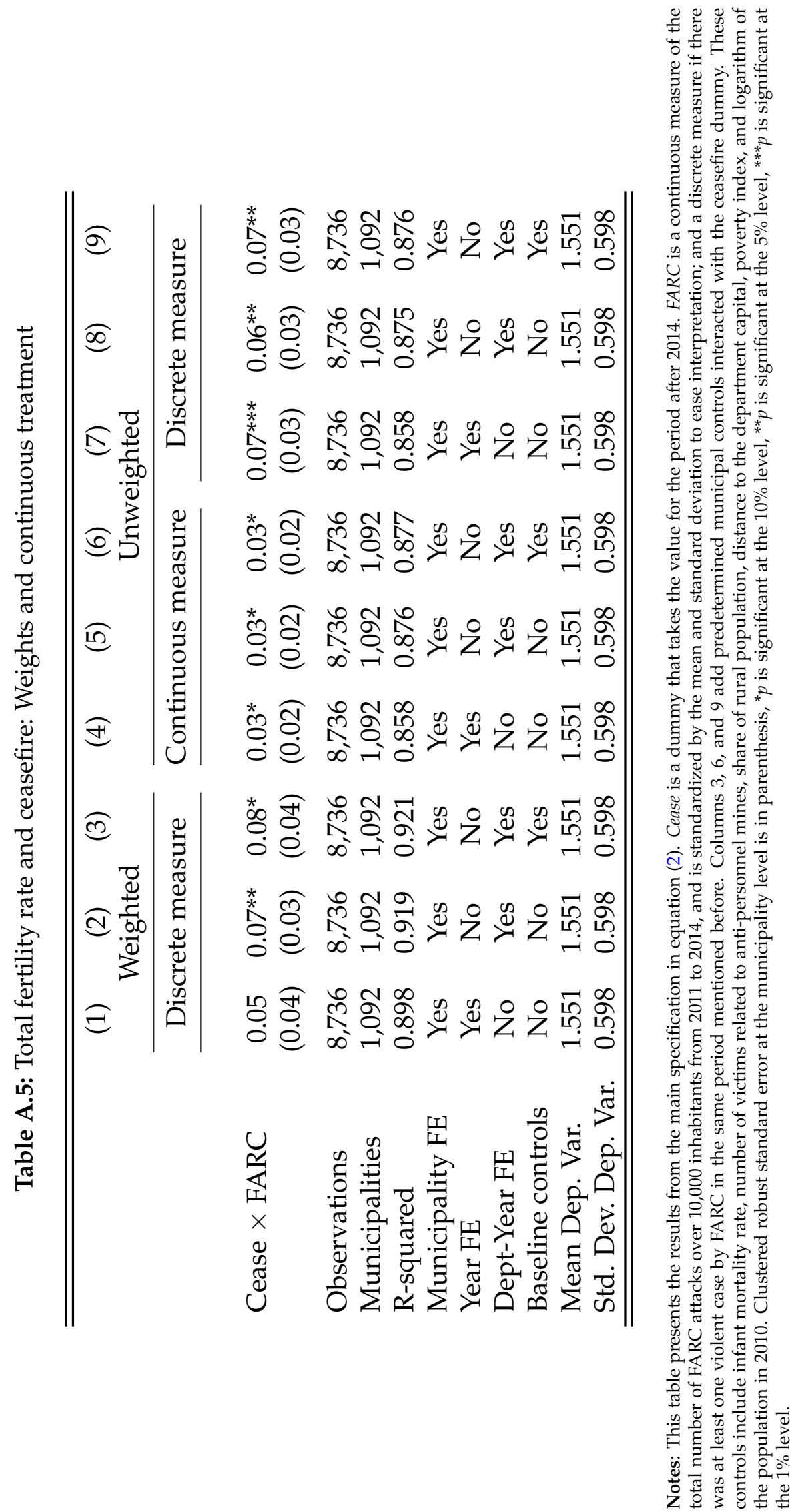
Table A.6: Drop most FARC-affected municipalities

\begin{tabular}{|c|c|c|c|c|c|c|c|c|}
\hline & $(1)$ & $(2)$ & $(3)$ & $(4)$ & $(5)$ & (6) & $(7)$ & (8) \\
\hline & \multicolumn{8}{|c|}{ Drop top FARC affected municipalities } \\
\hline & \multicolumn{2}{|c|}{ Top 2} & \multicolumn{2}{|c|}{ Top 4} & \multicolumn{2}{|c|}{ Top 6} & \multicolumn{2}{|c|}{ Top 8} \\
\hline Cease $\times$ FARC & $\begin{array}{c}0.05^{* * *} \\
(0.01)\end{array}$ & $\begin{array}{c}0.04^{* * *} \\
(0.01)\end{array}$ & $\begin{array}{l}0.04^{* *} \\
(0.02)\end{array}$ & $\begin{array}{l}0.04^{* *} \\
(0.02)\end{array}$ & $\begin{array}{l}0.05^{* *} \\
(0.02)\end{array}$ & $\begin{array}{l}0.04^{* *} \\
(0.02)\end{array}$ & $\begin{array}{l}0.05^{* *} \\
(0.03)\end{array}$ & $\begin{array}{l}0.05^{* *} \\
(0.02)\end{array}$ \\
\hline Observations & 8,720 & 8,720 & 8,704 & 8,704 & 8,688 & 8,688 & 8,672 & 8,672 \\
\hline R-squared & 0.899 & 0.919 & 0.899 & 0.919 & 0.899 & 0.920 & 0.899 & 0.920 \\
\hline Municipality FE & Yes & Yes & Yes & Yes & Yes & Yes & Yes & Yes \\
\hline Year FE & Yes & No & Yes & No & Yes & No & Yes & No \\
\hline Dept-Year FE & No & Yes & No & Yes & No & Yes & No & Yes \\
\hline Municipalities & 1090 & 1090 & 1088 & 1088 & 1086 & 1086 & 1084 & 1084 \\
\hline Mean Dep. Var. & 1.550 & 1.550 & 1.549 & 1.549 & 1.549 & 1.549 & 1.548 & 1.548 \\
\hline Std. Dev. Dep. Var. & 0.597 & 0.597 & 0.596 & 0.596 & 0.597 & 0.597 & 0.596 & 0.596 \\
\hline
\end{tabular}

Notes: This table presents the results from the main specification in equation (2), but dropping the most FARC-affected municipalities. All regressions are weighted by the number of live births between 2011 to 2014 for each age group. Cease is a dummy that takes the value for the period after 2014. FARC is a continuous measure of the total number of FARC attacks over 10,000 inhabitants from 2011 to 2014 and is standardized by the mean and standard deviation to ease interpretation. Clustered robust standard error at the municipality level are presented in parenthesis. ${ }^{*} p$ is significant at the $10 \%$ level, ${ }^{* *} p$ is significant at the $5 \%$ level, ${ }^{* * *} p$ is significant at the $1 \%$ level. 
Table A.7: Different time windows for measuring FARC

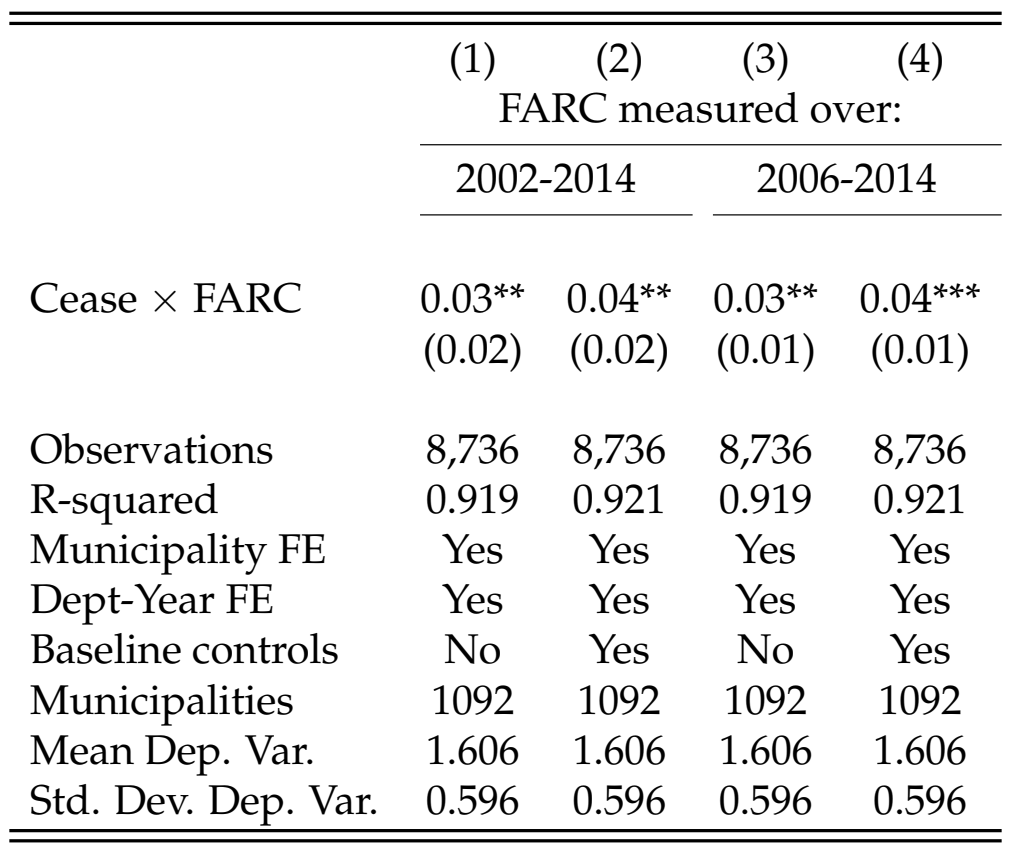

Notes: This table presents the results from the main specification in equation (2). All regressions are weighted by the number of live births between 2011 to 2014 for each age group. Cease is a dummy that takes the value for the period after 2014 . In columns 1 and 2 (3 and 4), FARC is a continuous measure of the total number of FARC attacks over 10,000 inhabitants from 2002 to 2014 (2006 to 2014), and is standardized by the mean and standard deviation to ease interpretation. Columns 2 and 4 add predetermined municipal controls interacted with the ceasefire dummy. These controls include infant mortality rate, number of victims related to anti-personnel mines, share of rural population, distance to the department capital, poverty index, and logarithm of the population in 2010. Clustered robust standard error at the municipality level are presented in parenthesis. ${ }^{*} p$ is significant at the $10 \%$ level, ${ }^{* *} p$ is significant at the $5 \%$ level, ${ }^{* * *} p$ is significant at the $1 \%$ level. 
Table A.8: Total fertility rate and ceasefire: Other weights

\begin{tabular}{|c|c|c|c|c|c|c|}
\hline \multirow[b]{2}{*}{ Weight: } & (1) & (2) & (3) & (4) & (5) & (6) \\
\hline & \multicolumn{3}{|c|}{ All population } & \multicolumn{3}{|c|}{ Female population } \\
\hline Cease $\times$ FARC & $\begin{array}{c}0.04^{* * *} \\
(0.01)\end{array}$ & $\begin{array}{c}0.04^{* * *} \\
(0.01)\end{array}$ & $\begin{array}{c}0.04^{* * *} \\
(0.01)\end{array}$ & $\begin{array}{c}0.04^{* * *} \\
(0.01)\end{array}$ & $\begin{array}{c}0.04^{* * *} \\
(0.01)\end{array}$ & $\begin{array}{c}0.04^{* * *} \\
(0.01)\end{array}$ \\
\hline Observations & 8,736 & 8,736 & 8,736 & 8,736 & 8,736 & 8,736 \\
\hline R-squared & 0.901 & 0.918 & 0.920 & 0.901 & 0.919 & 0.921 \\
\hline Municipality FE & Yes & Yes & Yes & Yes & Yes & Yes \\
\hline Year FE & Yes & No & No & Yes & No & No \\
\hline Dept-Year FE & No & Yes & Yes & No & Yes & Yes \\
\hline Baseline controls & No & No & Yes & No & No & Yes \\
\hline Municipalities & 1092 & 1092 & 1092 & 1092 & 1092 & 1092 \\
\hline Mean Dep. Var. & 1.551 & 1.551 & 1.551 & 1.551 & 1.551 & 1.551 \\
\hline Std. Dev. Dep. Var. & 0.598 & 0.598 & 0.598 & 0.598 & 0.598 & 0.598 \\
\hline
\end{tabular}

Notes: This table presents the results from the main specification in equation (2), but using different weights. Columns 1 to 3 use the total population as weight, while columns 4 to 6 use the female population, both measured in 2014. Cease is a dummy that takes the value for the period after 2014. FARC is a continuous measure of the total number of FARC attacks over 10,000 inhabitants from 2011 to 2014, and is standardized by the mean and standard deviation to ease interpretation. Columns 3 and 6 add predetermined municipal controls interacted with the ceasefire dummy. These controls include infant mortality rate, number of victims related to anti-personnel mines, share of rural population, distance to the department capital, poverty index, and logarithm of the population in 2010. Clustered robust standard error at the municipality level is in parenthesis, ${ }^{*} p$ is significant at the $10 \%$ level, ${ }^{* *} p$ is significant at the $5 \%$ level, ${ }^{* * *} p$ is significant at the $1 \%$ level. 
Table A.9: Birth rate and ceasefire

\begin{tabular}{lccc}
\hline \hline & $(1)$ & $\begin{array}{c}(2) \\
\text { Birth Rate }\end{array}$ \\
\cline { 2 - 4 } & \multicolumn{3}{c}{$(3)$} \\
Cease $\times$ FARC & $0.40^{* * *}$ & $0.36^{* * *}$ & $0.37^{* * *}$ \\
& $(0.12)$ & $(0.11)$ & $(0.12)$ \\
Observations & 8,736 & 8,736 & 8,736 \\
R-squared & 0.910 & 0.929 & 0.931 \\
Municipality FE & Yes & Yes & Yes \\
Year FE & Yes & No & No \\
Dept-Year FE & No & Yes & Yes \\
Baseline controls & No & No & Yes \\
Municipalities & 1092 & 1092 & 1092 \\
Mean Dep. Var. & 11.955 & 11.955 & 11.955 \\
Std. Dev. Dep. Var. & 4.818 & 4.818 & 4.818 \\
\hline \hline
\end{tabular}

Notes: This table presents the results from the main specification in equation (2) but using as dependent variable the birth rate. All regressions are weighted by the number of live births between 2011 to 2014 for each age group. Cease is a dummy that takes the value for the period after 2014. FARC is a continuous measure of the total number of FARC attacks over 10,000 inhabitants from 2011 to 2014 , and is standardized by the mean and standard deviation to ease interpretation. Birth Rate is computed as the total number of births per 1,000 individuals. Column 3 adds predetermined municipal controls interacted with the ceasefire dummy. These controls include infant mortality rate, number of victims related to anti-personnel mines, share of rural population, distance to the department capital, poverty index, and logarithm of the population in 2010. Clustered robust standard errors at the municipality level are presented in parenthesis. ${ }^{*} p$ is significant at the $10 \%$ level, ${ }^{* *} p$ is significant at the $5 \%$ level, ${ }^{* * *} p$ is significant at the $1 \%$ level. 
Table A.10: Test for differential pre-trends

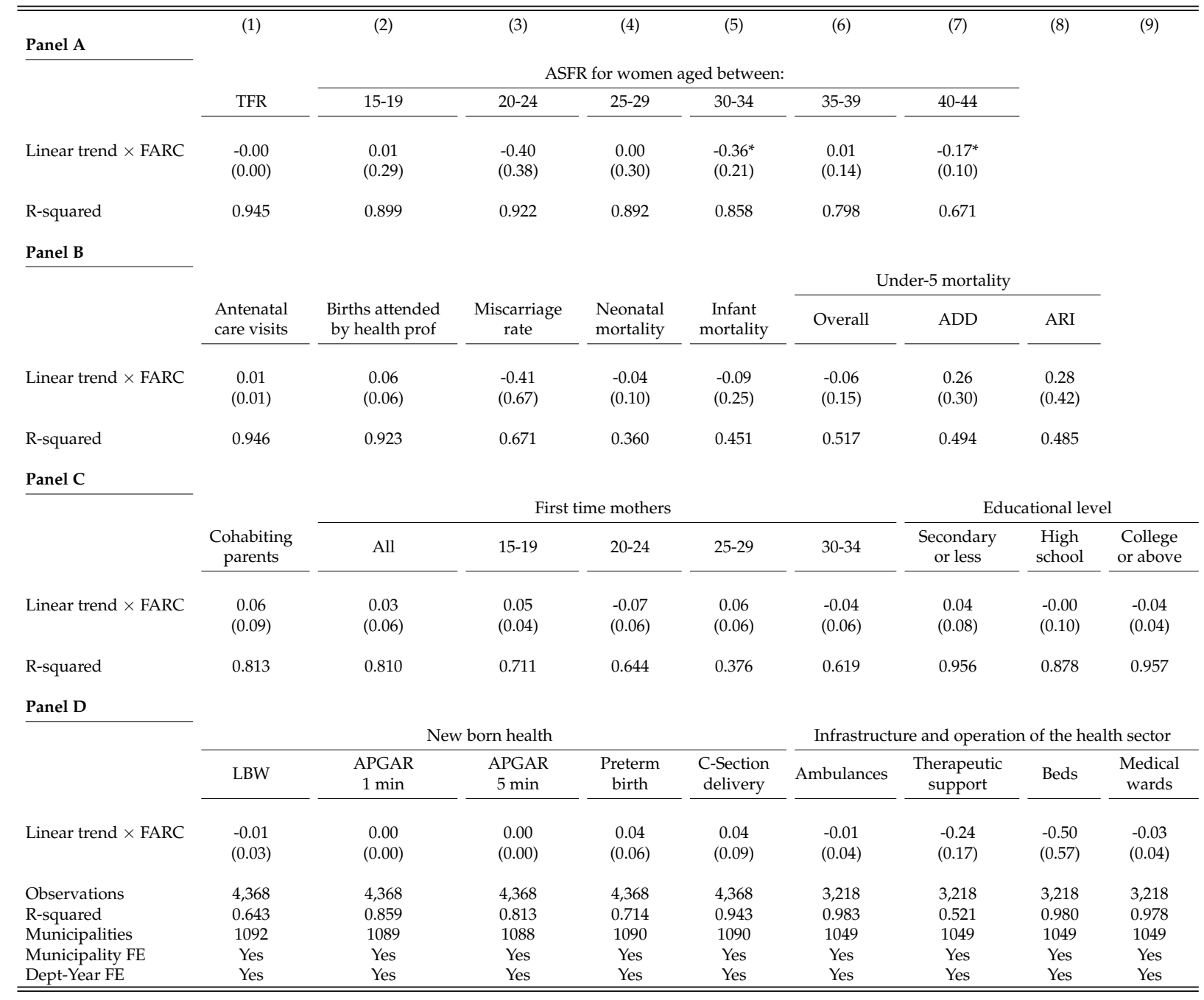

Notes: This table presents the results from a regression in the pre-ceasefire period (2011-2014) where the coefficient of interest is the interaction between a linear trend and FARC, and we include municipality and department-year fixed effects. All regressions are weighted by the number of live births between 2011 to 2014 for each age group. FARC is a continuous measure of the total number of FARC attacks over 10,000 inhabitants from 2011 to 2014, and is standardized by the mean and standard deviation to ease interpretation. The dependent variables are the ones presented in Tables 1, 2, 4, 5, and 6. Clustered robust standard errors at the municipality level are presented in parenthesis. ${ }^{*} p$ is significant at the $10 \%$ level, ${ }^{* *} p$ is significant at the $5 \%$ level, ${ }^{* * *} p$ is significant at the $1 \%$ level. 
Table A.11: Placebo treatment in 2012

\begin{tabular}{|c|c|c|c|c|c|c|c|c|c|}
\hline Panel A & (1) & (2) & (3) & (4) & (5) & (6) & (7) & (8) & (9) \\
\hline & & \multicolumn{6}{|c|}{ ASFR for women aged between: } & & \\
\hline & TFR & $15-19$ & $20-24$ & $25-29$ & $30-34$ & $35-39$ & $40-44$ & & \\
\hline Placebo $\times$ FARC & $\begin{array}{l}-0.01 \\
(0.01)\end{array}$ & $\begin{array}{c}0.23 \\
(0.76)\end{array}$ & $\begin{array}{l}-1.39 \\
(1.01)\end{array}$ & $\begin{array}{c}0.92 \\
(0.78)\end{array}$ & $\begin{array}{l}-0.75 \\
(0.48)\end{array}$ & $\begin{array}{l}-0.00 \\
(0.31)\end{array}$ & $\begin{array}{l}-0.56^{* *} \\
(0.25)\end{array}$ & & \\
\hline Observations & 4,368 & 4,368 & 4,368 & 4,368 & 4,368 & 4,368 & 4,368 & & \\
\hline R-squared & 0.945 & 0.899 & 0.922 & 0.892 & 0.858 & 0.798 & 0.671 & & \\
\hline \multicolumn{10}{|l|}{ Panel B } \\
\hline & & & & & & \multicolumn{3}{|c|}{ Under-5 mortality } & \\
\hline & $\begin{array}{l}\text { Antenatal } \\
\text { care visits }\end{array}$ & $\begin{array}{l}\text { Births attended } \\
\text { by health prof }\end{array}$ & $\begin{array}{l}\text { Miscarriage } \\
\text { rate }\end{array}$ & $\begin{array}{l}\text { Neonatal } \\
\text { mortality }\end{array}$ & $\begin{array}{c}\text { Infant } \\
\text { mortality }\end{array}$ & Overall & ADD & ARI & \\
\hline Placebo $\times$ FARC & $\begin{array}{c}0.02 \\
(0.01)\end{array}$ & $\begin{array}{c}0.02 \\
(0.13)\end{array}$ & $\begin{array}{l}-0.33 \\
(1.18)\end{array}$ & $\begin{array}{l}-0.22 \\
(0.29)\end{array}$ & $\begin{array}{l}-0.42 \\
(0.80)\end{array}$ & $\begin{array}{l}-0.11 \\
(0.46)\end{array}$ & $\begin{array}{c}0.76 \\
(0.79)\end{array}$ & $\begin{array}{l}-0.45 \\
(1.17)\end{array}$ & \\
\hline Observations & 4,368 & 4,368 & 4,251 & 4,368 & 4,368 & 4,368 & 4,368 & 4,368 & \\
\hline R-squared & 0.946 & 0.923 & 0.671 & 0.360 & 0.451 & 0.517 & 0.494 & 0.485 & \\
\hline \multicolumn{10}{|l|}{ Panel C } \\
\hline & & \multicolumn{5}{|c|}{ First time mothers } & \multicolumn{3}{|c|}{ Educational level } \\
\hline & $\begin{array}{l}\text { Cohabiting } \\
\text { parents }\end{array}$ & All & $15-19$ & $20-24$ & $25-29$ & $30-34$ & $\begin{array}{l}\text { Secondary } \\
\text { or less }\end{array}$ & $\begin{array}{l}\text { High } \\
\text { school }\end{array}$ & $\begin{array}{l}\text { College } \\
\text { or above }\end{array}$ \\
\hline Placebo $\times$ FARC & $\begin{array}{c}0.07 \\
(0.27)\end{array}$ & $\begin{array}{c}0.06 \\
(0.14)\end{array}$ & $\begin{array}{l}0.14^{*} \\
(0.08)\end{array}$ & $\begin{array}{c}-0.41^{* * *} \\
(0.13)\end{array}$ & $\begin{array}{c}0.47^{* * *} \\
(0.15)\end{array}$ & $\begin{array}{l}-0.09 \\
(0.14)\end{array}$ & $\begin{array}{c}0.16 \\
(0.16)\end{array}$ & $\begin{array}{l}-0.12 \\
(0.20)\end{array}$ & $\begin{array}{l}-0.04 \\
(0.12)\end{array}$ \\
\hline R-squared & 0.813 & 0.810 & 0.711 & 0.644 & 0.378 & 0.619 & 0.956 & 0.878 & 0.957 \\
\hline \multicolumn{10}{|l|}{ Panel D } \\
\hline & \multicolumn{5}{|c|}{ New born health } & \multicolumn{4}{|c|}{ Infrastructure and operation of the health sector } \\
\hline & LBW & $\begin{array}{l}\text { APGAR } \\
1 \mathrm{~min}\end{array}$ & $\begin{array}{l}\text { APGAR } \\
5 \mathrm{~min}\end{array}$ & $\begin{array}{l}\text { Preterm } \\
\text { birth }\end{array}$ & $\begin{array}{l}\text { C-Section } \\
\text { delivery }\end{array}$ & Ambulances & $\begin{array}{c}\text { Therapeutic } \\
\text { support }\end{array}$ & Beds & $\begin{array}{c}\text { Medical } \\
\text { wards }\end{array}$ \\
\hline Placebo $\times$ FARC & $\begin{array}{l}-0.05 \\
(0.07)\end{array}$ & $\begin{array}{c}0.00 \\
(0.01)\end{array}$ & $\begin{array}{c}0.01 \\
(0.01)\end{array}$ & $\begin{array}{c}0.18 \\
(0.13)\end{array}$ & $\begin{array}{c}0.07 \\
(0.22)\end{array}$ & & & & \\
\hline Observations & 4,368 & 4,368 & 4,368 & 4,368 & 4,368 & & & & \\
\hline R-squared & 0.643 & 0.859 & 0.813 & 0.714 & 0.943 & & & & \\
\hline Municipality FE & Yes & Yes & Yes & Yes & Yes & Yes & Yes & Yes & Yes \\
\hline Dept-Year FE & Yes & Yes & Yes & Yes & Yes & Yes & Yes & Yes & Yes \\
\hline
\end{tabular}

Notes: This table presents the results from the main specification in equation (2), but restricting the sample to the pre-ceasefire period (2011-2014). All regressions are weighted by the number of live births between 2011 to 2014 for each age group. Placebo is a dummy that takes the value for the years 2012, 2013, and 2014. FARC is a continuous measure of the total number of FARC attacks over 10,000 inhabitants from 2011 to 2014, and is standardized by the mean and standard deviation to ease interpretation. The dependent variables are the ones presented in Tables 1, 2, 4, 5, and 6. Clustered robust standard errors at the municipality level are presented in parenthesis. ${ }^{*} p$ is significant at the $10 \%$ level, ${ }^{* *} p$ is significant at the $5 \%$ level, ${ }^{* * *} p$ is significant at the $1 \%$ level. 
Table A.12: Placebo treatment in 2013

\begin{tabular}{|c|c|c|c|c|c|c|c|c|c|}
\hline Panel A & (1) & (2) & (3) & (4) & (5) & (6) & (7) & (8) & (9) \\
\hline & & \multicolumn{6}{|c|}{ ASFR for women aged between: } & & \\
\hline & TFR & $15-19$ & $20-24$ & $25-29$ & $30-34$ & $35-39$ & $40-44$ & & \\
\hline Placebo $\times$ FARC & $\begin{array}{l}-0.01 \\
(0.01)\end{array}$ & $\begin{array}{l}-0.29 \\
(0.67)\end{array}$ & $\begin{array}{l}-0.36 \\
(0.79)\end{array}$ & $\begin{array}{c}0.00 \\
(0.63)\end{array}$ & $\begin{array}{l}-0.85^{*} \\
(0.44)\end{array}$ & $\begin{array}{l}-0.11 \\
(0.40)\end{array}$ & $\begin{array}{l}-0.33 \\
(0.25)\end{array}$ & & \\
\hline R-squared & 0.945 & 0.899 & 0.922 & 0.892 & 0.858 & 0.798 & 0.671 & & \\
\hline \multicolumn{10}{|l|}{ Panel B } \\
\hline & & & & & & \multicolumn{3}{|c|}{ Under-5 mortality } & \\
\hline & $\begin{array}{l}\text { Antenatal } \\
\text { care visits }\end{array}$ & $\begin{array}{l}\text { Births attended } \\
\text { by health prof }\end{array}$ & $\begin{array}{l}\text { Miscarriage } \\
\text { rate }\end{array}$ & $\begin{array}{l}\text { Neonatal } \\
\text { mortality }\end{array}$ & $\begin{array}{l}\text { Infant } \\
\text { mortality }\end{array}$ & Overall & ADD & ARI & \\
\hline Placebo $\times$ FARC & $\begin{array}{c}0.02 \\
(0.01)\end{array}$ & $\begin{array}{c}0.18 \\
(0.13)\end{array}$ & $\begin{array}{l}-0.91 \\
(1.32)\end{array}$ & $\begin{array}{l}-0.00 \\
(0.25)\end{array}$ & $\begin{array}{l}-0.15 \\
(0.55)\end{array}$ & $\begin{array}{l}-0.09 \\
(0.32)\end{array}$ & $\begin{array}{l}1.07 \\
(1.00)\end{array}$ & $\begin{array}{l}1.20 \\
(1.19)\end{array}$ & \\
\hline R-squared & 0.946 & 0.923 & 0.671 & 0.360 & 0.451 & 0.517 & 0.495 & 0.485 & \\
\hline \multicolumn{10}{|l|}{ Panel C } \\
\hline & & \multicolumn{5}{|c|}{ First time mothers } & \multicolumn{3}{|c|}{ Educational level } \\
\hline & $\begin{array}{c}\text { Cohabiting } \\
\text { parents }\end{array}$ & All & $15-19$ & $20-24$ & $25-29$ & $30-34$ & $\begin{array}{c}\text { Secondary } \\
\text { or less }\end{array}$ & $\begin{array}{l}\text { High } \\
\text { school }\end{array}$ & $\begin{array}{l}\text { College } \\
\text { or above }\end{array}$ \\
\hline Placebo $\times$ FARC & $\begin{array}{c}0.13 \\
(0.19)\end{array}$ & $\begin{array}{l}-0.00 \\
(0.15)\end{array}$ & $\begin{array}{c}0.11 \\
(0.11)\end{array}$ & $\begin{array}{l}-0.06 \\
(0.14)\end{array}$ & $\begin{array}{c}0.10 \\
(0.13)\end{array}$ & $\begin{array}{l}-0.16 \\
(0.11)\end{array}$ & $\begin{array}{c}0.13 \\
(0.18)\end{array}$ & $\begin{array}{l}-0.12 \\
(0.25)\end{array}$ & $\begin{array}{l}-0.01 \\
(0.12)\end{array}$ \\
\hline R-squared & 0.813 & 0.810 & 0.711 & 0.643 & 0.376 & 0.620 & 0.956 & 0.878 & 0.957 \\
\hline \multicolumn{10}{|l|}{ Panel D } \\
\hline & \multicolumn{5}{|c|}{ New born health } & \multicolumn{4}{|c|}{ Infrastructure and operation of the health sector } \\
\hline & LBW & $\begin{array}{l}\text { APGAR } \\
1 \mathrm{~min}\end{array}$ & $\begin{array}{l}\text { APGAR } \\
5 \mathrm{~min}\end{array}$ & $\begin{array}{l}\text { Preterm } \\
\text { birth }\end{array}$ & $\begin{array}{l}\text { C-Section } \\
\text { delivery }\end{array}$ & Ambulances & $\begin{array}{c}\text { Therapeutic } \\
\text { support }\end{array}$ & Beds & $\begin{array}{c}\text { Medical } \\
\text { wards }\end{array}$ \\
\hline Placebo $\times$ FARC & $\begin{array}{c}0.02 \\
(0.06)\end{array}$ & $\begin{array}{l}-0.00 \\
(0.00)\end{array}$ & $\begin{array}{c}0.00 \\
(0.01)\end{array}$ & $\begin{array}{c}0.04 \\
(0.13)\end{array}$ & $\begin{array}{c}0.07 \\
(0.20)\end{array}$ & $\begin{array}{l}-0.01 \\
(0.06)\end{array}$ & $\begin{array}{l}-0.31 \\
(0.19)\end{array}$ & $\begin{array}{l}-0.47 \\
(0.96)\end{array}$ & $\begin{array}{l}-0.03 \\
(0.07)\end{array}$ \\
\hline Observations & 4,368 & 4,368 & 4,368 & 4,368 & 4,368 & 3,218 & 3,218 & 3,218 & 3,218 \\
\hline R-squared & 0.643 & 0.859 & 0.813 & 0.714 & 0.943 & 0.983 & 0.521 & 0.980 & 0.978 \\
\hline Municipality FE & Yes & Yes & Yes & Yes & Yes & Yes & Yes & Yes & Yes \\
\hline Dept-Year FE & Yes & Yes & Yes & Yes & Yes & Yes & Yes & Yes & Yes \\
\hline
\end{tabular}

Notes: This table presents the results from the main specification in equation (2), but restricting the sample to the pre-ceasefire period (2011-2014). All regressions are weighted by the number of live births between 2011 to 2014 for each age group. Placebo is a dummy that takes the value for the years 2013 and 2014. FARC is a continuous measure of the total number of FARC attacks over 10,000 inhabitants from 2011 to 2014, and is standardized by the mean and standard deviation to ease interpretation. The dependent variables are the ones presented in Tables 1, 2, 4, 5, and 6. Clustered robust standard errors at the municipality level are presented in parenthesis. ${ }^{*} p$ is significant at the $10 \%$ level, ${ }^{* *} p$ is significant at the $5 \%$ level, ${ }^{* * *} p$ is significant at the $1 \%$ level. 
Table A.13: Placebo treatment in 2014

\begin{tabular}{|c|c|c|c|c|c|c|c|c|c|}
\hline Panel A & (1) & (2) & (3) & (4) & (5) & (6) & (7) & (8) & (9) \\
\hline & & \multicolumn{6}{|c|}{ ASFR for women aged between: } & & \\
\hline & TFR & $15-19$ & $20-24$ & $25-29$ & $30-34$ & $35-39$ & $40-44$ & & \\
\hline Placebo $\times$ FARC & $\begin{array}{l}-0.01 \\
(0.01)\end{array}$ & $\begin{array}{c}0.21 \\
(0.72)\end{array}$ & $\begin{array}{l}-0.81 \\
(0.83)\end{array}$ & $\begin{array}{l}-0.91 \\
(0.78)\end{array}$ & $\begin{array}{l}-0.53 \\
(0.55)\end{array}$ & $\begin{array}{c}0.21 \\
(0.38)\end{array}$ & $\begin{array}{l}-0.11 \\
(0.30)\end{array}$ & & \\
\hline R-squared & 0.945 & 0.899 & 0.922 & 0.892 & 0.858 & 0.798 & 0.671 & & \\
\hline \multicolumn{10}{|l|}{ Panel B } \\
\hline & & & & & & \multicolumn{3}{|c|}{ Under-5 mortality } & \\
\hline & $\begin{array}{l}\text { Antenatal } \\
\text { care visits }\end{array}$ & $\begin{array}{l}\text { Births attended } \\
\text { by health prof }\end{array}$ & $\begin{array}{l}\text { Miscarriage } \\
\text { rate }\end{array}$ & $\begin{array}{l}\text { Neonatal } \\
\text { mortality }\end{array}$ & $\begin{array}{l}\text { Infant } \\
\text { mortality }\end{array}$ & Overall & $\mathrm{ADD}$ & ARI & \\
\hline Placebo $\times$ FARC & $\begin{array}{c}0.01 \\
(0.01)\end{array}$ & $\begin{array}{c}0.13 \\
(0.13)\end{array}$ & $\begin{array}{l}-1.20 \\
(1.99)\end{array}$ & $\begin{array}{l}-0.02 \\
(0.23)\end{array}$ & $\begin{array}{c}0.04 \\
(0.67)\end{array}$ & $\begin{array}{l}-0.16 \\
(0.39)\end{array}$ & $\begin{array}{l}-0.49 \\
(0.62)\end{array}$ & $\begin{array}{c}0.76 \\
(0.87)\end{array}$ & \\
\hline R-squared & 0.946 & 0.923 & 0.671 & 0.360 & 0.451 & 0.517 & 0.494 & 0.485 & \\
\hline \multicolumn{10}{|l|}{ Panel C } \\
\hline & & \multicolumn{5}{|c|}{ First time mothers } & \multicolumn{3}{|c|}{ Educational level } \\
\hline & $\begin{array}{l}\text { Cohabiting } \\
\text { parents }\end{array}$ & All & $15-19$ & $20-24$ & $25-29$ & $30-34$ & $\begin{array}{l}\text { Secondary } \\
\text { or less }\end{array}$ & $\begin{array}{l}\text { High } \\
\text { school }\end{array}$ & $\begin{array}{l}\text { College } \\
\text { or above }\end{array}$ \\
\hline Placebo $\times$ FARC & $\begin{array}{c}0.18 \\
(0.21)\end{array}$ & $\begin{array}{c}0.14 \\
(0.13)\end{array}$ & $\begin{array}{c}0.05 \\
(0.08)\end{array}$ & $\begin{array}{c}0.01 \\
(0.19)\end{array}$ & $\begin{array}{l}-0.21 \\
(0.16)\end{array}$ & $\begin{array}{c}0.02 \\
(0.16)\end{array}$ & $\begin{array}{l}-0.10 \\
(0.21)\end{array}$ & $\begin{array}{c}0.28 \\
(0.22)\end{array}$ & $\begin{array}{l}-0.19 \\
(0.12)\end{array}$ \\
\hline R-squared & 0.813 & 0.810 & 0.711 & 0.643 & 0.376 & 0.619 & 0.956 & 0.878 & 0.957 \\
\hline \multicolumn{10}{|l|}{ Panel D } \\
\hline & \multicolumn{5}{|c|}{ New born health } & \multicolumn{4}{|c|}{ Infrastructure and operation of the health sector } \\
\hline & LBW & $\begin{array}{l}\text { APGAR } \\
1 \mathrm{~min}\end{array}$ & $\begin{array}{l}\text { APGAR } \\
5 \mathrm{~min}\end{array}$ & $\begin{array}{l}\text { Preterm } \\
\text { birth }\end{array}$ & $\begin{array}{l}\text { C-Section } \\
\text { delivery }\end{array}$ & Ambulances & $\begin{array}{c}\text { Therapeutic } \\
\text { support }\end{array}$ & Beds & $\begin{array}{l}\text { Medical } \\
\text { wards }\end{array}$ \\
\hline Placebo $\times$ FARC & $\begin{array}{l}-0.03 \\
(0.09)\end{array}$ & $\begin{array}{c}0.01 \\
(0.01)\end{array}$ & $\begin{array}{l}0.01^{*} \\
(0.00)\end{array}$ & $\begin{array}{l}-0.00 \\
(0.13)\end{array}$ & $\begin{array}{c}0.12 \\
(0.19)\end{array}$ & $\begin{array}{l}-0.01 \\
(0.06)\end{array}$ & $\begin{array}{l}-0.41 \\
(0.32)\end{array}$ & $\begin{array}{l}-1.03 \\
(0.84)\end{array}$ & $\begin{array}{l}-0.07 \\
(0.05)\end{array}$ \\
\hline Observations & 4,368 & 4,368 & 4,368 & 4,368 & 4,368 & 3,218 & 3,218 & 3,218 & 3,218 \\
\hline R-squared & 0.643 & 0.860 & 0.813 & 0.714 & 0.943 & 0.983 & 0.521 & 0.980 & 0.978 \\
\hline Municipality FE & Yes & Yes & Yes & Yes & Yes & Yes & Yes & Yes & Yes \\
\hline Dept-Year FE & Yes & Yes & Yes & Yes & Yes & Yes & Yes & Yes & Yes \\
\hline
\end{tabular}

Notes: This table presents the results from the main specification in equation (2), but restricting the sample to the pre-ceasefire period (2011-2014). All regressions are weighted by the number of live births between 2011 to 2014 for each age group. Placebo is a dummy that takes the value for the year 2014. FARC is a continuous measure of the total number of FARC attacks over 10,000 inhabitants from 2011 to 2014, and is standardized by the mean and standard deviation to ease interpretation. The dependent variables are the ones presented in Tables 1, 2, 4, 5, and 6. Clustered robust standard errors at the municipality level are presented in parenthesis. ${ }^{*} p$ is significant at the $10 \%$ level, ${ }^{* *} p$ is significant at the $5 \%$ level, ${ }^{* * *} p$ is significant at the $1 \%$ level. 
Table A.14: Treatment intensity and potential non linear effects

\begin{tabular}{lcc}
\hline \hline & $(1)$ & $(2)$ \\
& & \\
\cline { 2 - 3 } & & \\
Cease $\times$ FARC attack in top quartile & $0.20^{* *}$ & $0.19^{* *}$ \\
& $(0.08)$ & $(0.09)$ \\
Cease $\times$ Any FARC attack & 0.04 & 0.05 \\
& $(0.04)$ & $(0.04)$ \\
Observations & & \\
R-squared & 8,736 & 8,736 \\
Municipality FE & 0.919 & 0.921 \\
Year FE & Yes & Yes \\
Dept-Year FE & No & No \\
Baseline controls & Yes & Yes \\
Municipalities & No & Yes \\
Mean Dep. Var. & 1092 & 1092 \\
Std. Dev. Dep. Var. & 1.551 & 1.551 \\
\hline \hline
\end{tabular}

Notes: This table presents the results from the main specification in equation (2). All regressions are weighted by the number of live births between 2011 to 2014 for each age group. Cease is a dummy that takes the value for the period after 2014. Any FARC attack is a dummy that takes the value one if a municipality had at least one FARC attack attack between 2011 and 2014 . FARC attack in top quartile is a dummy that takes the value one if a municipality is in the top quartile of the empirical distribution of FARC attacks between 2011 and 2014 over total population. Total Fertility Rate is computed as the sum of age-specific fertility rates weighted by the number of years in each age group, divided by 1,000. Column 2 adds predetermined municipal controls interacted with the ceasefire dummy. These controls include infant mortality rate, number of victims related to anti-personnel mines, share of rural population, distance to the department capital, poverty index, and logarithm of the population in 2010. Clustered robust standard errors at the municipality level are presented in parenthesis. ${ }^{*} p$ is significant at the $10 \%$ level, ${ }^{* *} p$ is significant at the $5 \%$ level, ${ }^{* * *} p$ is significant at the $1 \%$ level. 
Table A.15: Differential effects after implementation

\begin{tabular}{lccc}
\hline \hline & $(1)$ & $(2)$ & $(3)$ \\
& \multicolumn{3}{c}{ Total Fertility } \\
\cline { 2 - 4 } & & & \\
Implemente & \\
& $0.03^{* * *}$ & $0.04^{* * *}$ & $0.04^{* * *}$ \\
Cease $\times$ FARC & $(0.01)$ & $(0.01)$ & $(0.01)$ \\
& $0.03^{* *}$ & $0.02^{* *}$ & $0.03^{* *}$ \\
Observations & $(0.01)$ & $(0.01)$ & $(0.01)$ \\
R-squared & & & \\
Municipality FE & 8,736 & 8,736 & 8,736 \\
Dept-Year FE & 0.899 & 0.920 & 0.922 \\
Baseline controls & Yes & Yes & Yes \\
Municipalities & No & Yes & Yes \\
Mean Dep. Var. & No & No & Yes \\
Std. Dev. Dep. Var. & 1092 & 1092 & 1092 \\
\hline \hline
\end{tabular}

Notes: This table presents the results from the main specification in equation (2). All regressions are weighted by the number of live births between 2011 to 2014 for each age group. Cease is a dummy that takes the value for the period after 2014, while Implementation is a dummy that takes the value one for 2017 and 2018. FARC is a continuous measure of the total number of FARC attacks over 10,000 inhabitants from 2011 to 2014, and is standardized by the mean and standard deviation to ease interpretation. Column 3 adds predetermined municipal controls interacted with the ceasefire dummy. These controls include infant mortality rate, number of victims related to anti-personnel mines, share of rural population, distance to the department capital, poverty index, and logarithm of the population in 2010. Clustered robust standard error at the municipality level are presented in parenthesis. ${ }^{*} p$ is significant at the $10 \%$ level, ${ }^{* *} p$ is significant at the $5 \%$ level, ${ }^{* * *} p$ is significant at the $1 \%$ level. 
Table A.16: Marriage markets

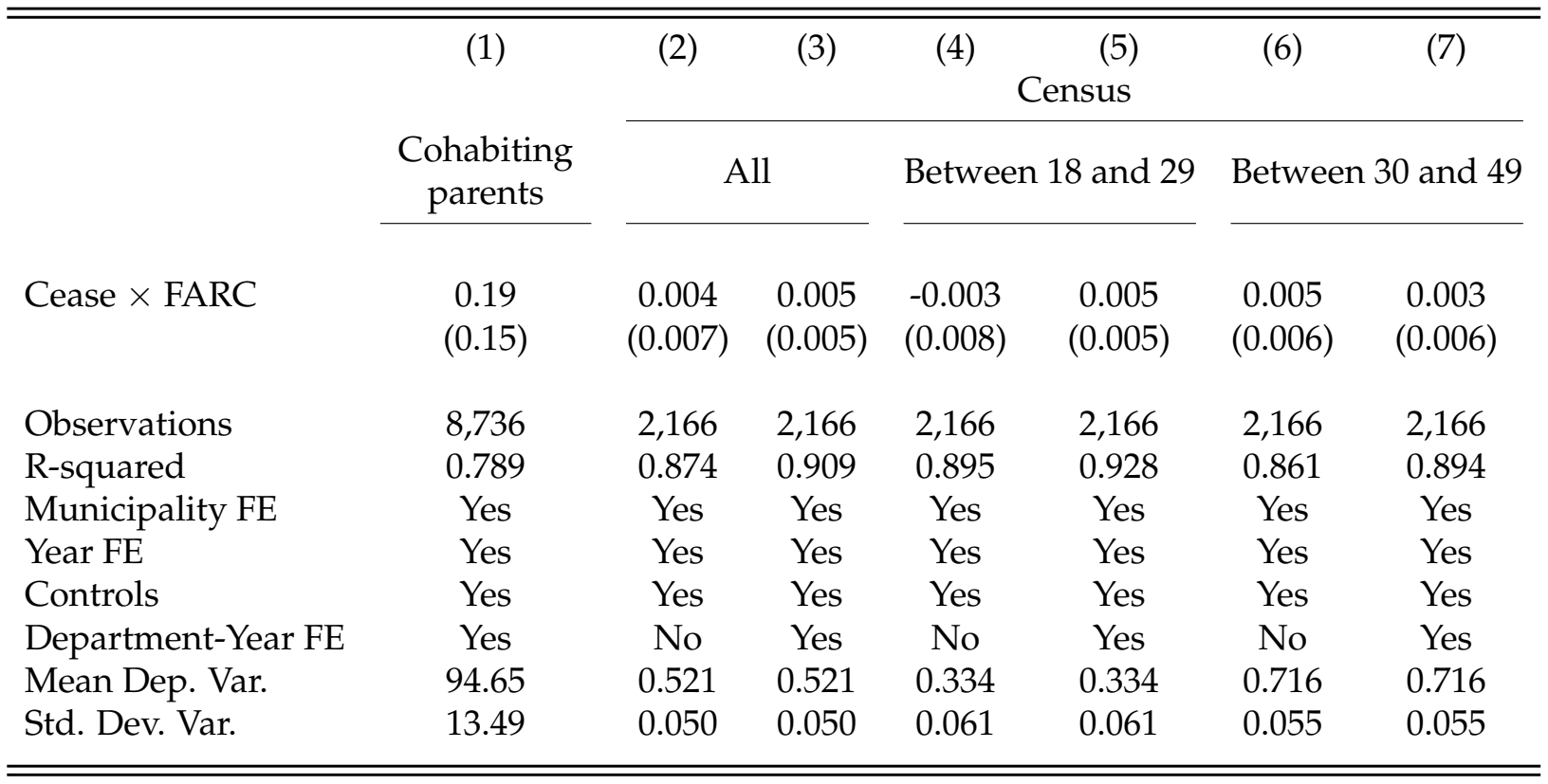

Notes: This table presents the results from the main specification in equation (2). In column 1, the dependent variable is the share of births from cohabiting parents. In columns 2 to 7 , the dependent variable is the share of the population ever married using data from the 2005 and 2018 Census. Columns 2 and 3 show the results for people between 18 and 49 years old, columns 4 and 5 for people between 18 and 29 years old, and columns 6 and 7 for people between 30 and 49 years old. Cease is a dummy that takes the value for the period after 2014. FARC a dummy variable that takes the value one if there was at least one violent case by FARC. All columns add predetermined municipal controls interacted with the ceasefire dummy. These controls include infant mortality rate, number of victims related to anti-personnel mines, share of rural population, distance to the department capital, poverty index, and logarithm of the population in 2010. Clustered robust standard error at the municipality level are presented in parenthesis. ${ }^{*} p$ is significant at the $10 \%$ level, ${ }^{* *} p$ is significant at the $5 \%$ level, ${ }^{* * *} p$ is significant at the $1 \%$ level. 


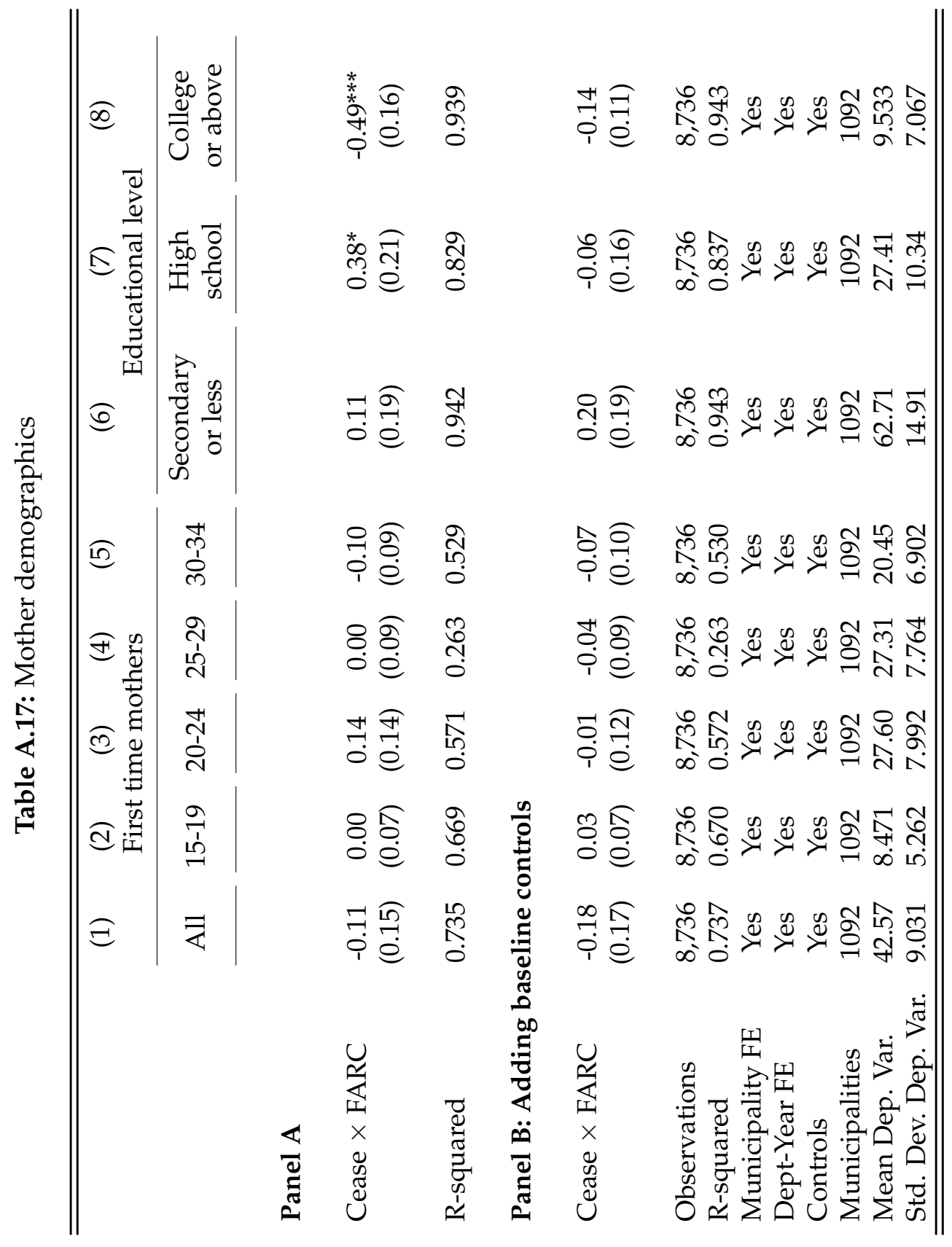

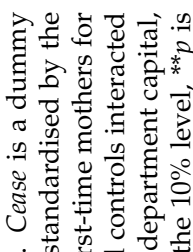

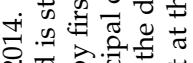

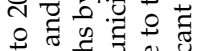

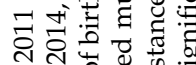

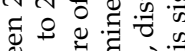

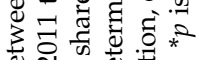
¿

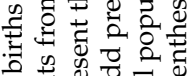

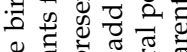

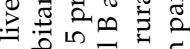
范苛

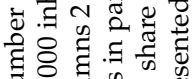

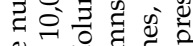

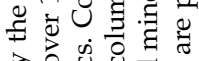
วิे 卷言专完

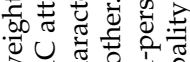

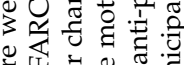

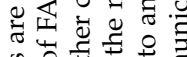

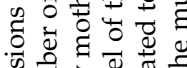

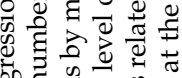

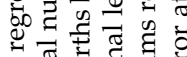

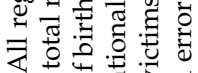

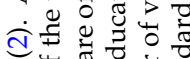
๘ 常密昰 ซृ ङ $\exists$ 表空

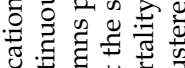

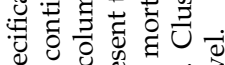
के $\sigma \stackrel{0}{=}$ 艺 0 क.

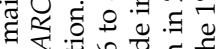
Q

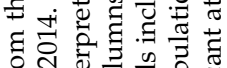
년

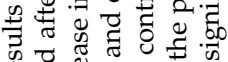
ఖ

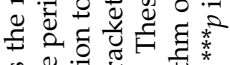

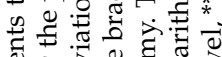

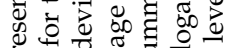

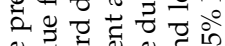

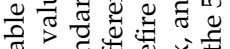
I 0 퓨워

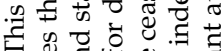
क्ष

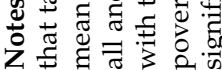

